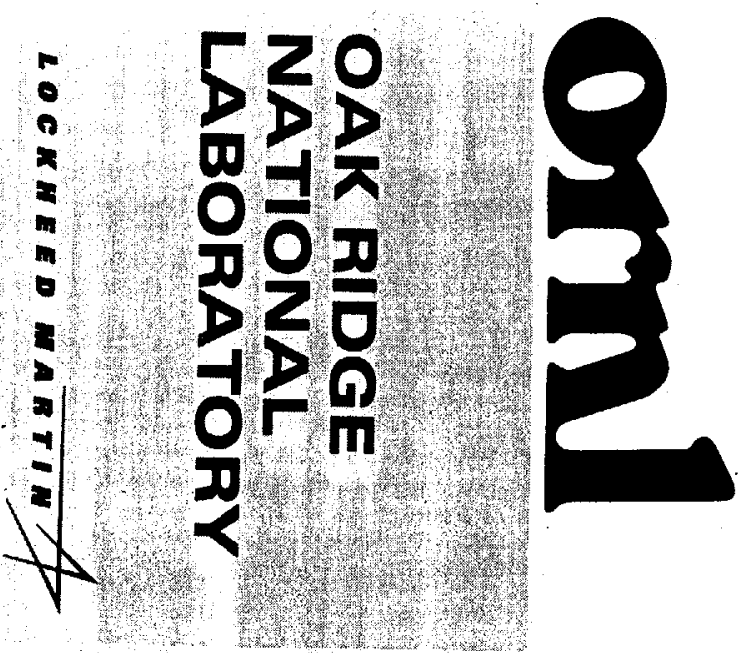

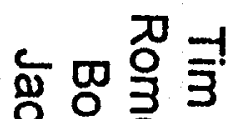

웃응 잉

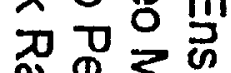

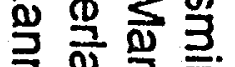

这全零怘

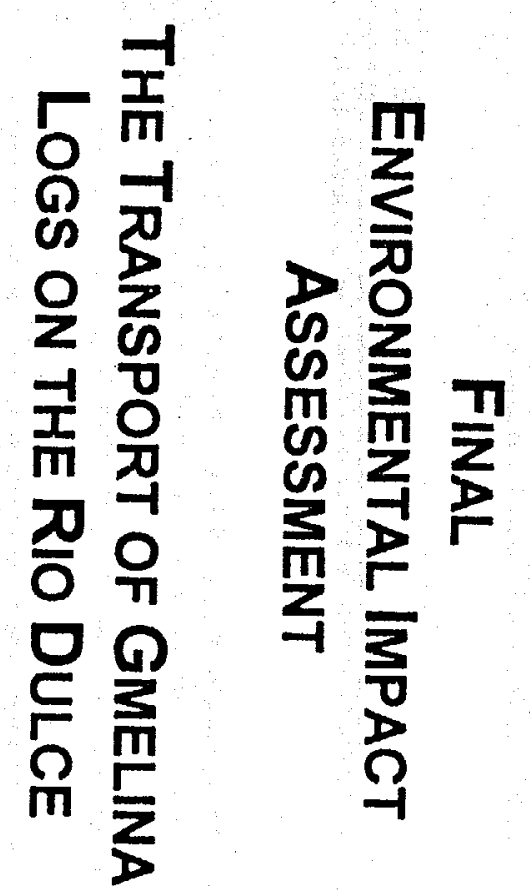





\title{
The Transport of Gmelina Logs on The Rio Dulce
}

\author{
Tim Ensminger \\ Romeo Martinez ${ }^{1}$ \\ Bob Perlack \\ Jack Ranney ${ }^{2}$
}

${ }^{1}$ U.S. Agency for International Development

${ }^{2}$ University of Tennessee

February 1997

Prepared for the

U.S. Agency for International Development and

Comisión Nacional del Medio Ambiente

Guatemala City, Guatemala

by the

OAK RIDGE NATIONAL LABORATORY

Oak Ridge, Tennessee 37831

managed by

LOCKHEED MARTIN ENERGY RESEARCH CORP.

for the

U.S. DEPARTMENT OF ENERGY

under Contract No. DE-AC05-960R22464 


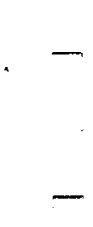




\section{TABLE OF CONTENTS}

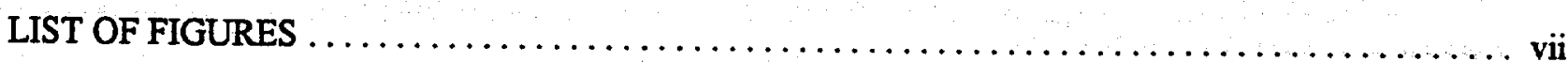

LIST OF TABLES $\ldots \ldots \ldots \ldots \ldots \ldots \ldots \ldots \ldots \ldots \ldots \ldots \ldots \ldots \ldots \ldots \ldots \ldots \ldots \ldots \ldots \ldots \ldots \ldots \ldots \ldots \ldots$

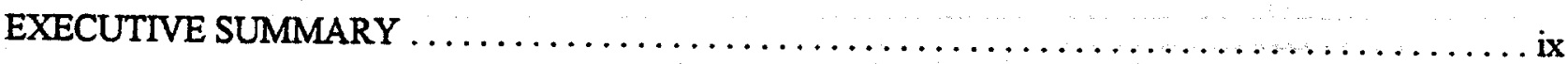

1. INTRODUCTION

1.1 PURPOSE ANDNEED FOR THE PROPOSED ACTION $\ldots \ldots \ldots \ldots \ldots \ldots \ldots \ldots \ldots \ldots \ldots$

1.2 BACKGROUND $\ldots \ldots \ldots \ldots \ldots \ldots \ldots \ldots \ldots \ldots \ldots \ldots \ldots \ldots \ldots$

1.3 SCOPE OF THE EIA $\ldots \ldots \ldots \ldots \ldots \ldots \ldots \ldots \ldots$

1.4 LEGAL AND POLICY FRAMEWORK

2. ALTERNATIVES INCLUDING THE PROPOSED ACTION $\ldots \ldots \ldots \ldots \ldots \ldots \ldots \ldots \ldots \ldots \ldots \ldots 7$

2.1 THE PROPOSED ACTION: TRUCK AND TRANSPORT LOGS VIA RIO DULCE $\ldots \ldots \ldots \ldots 7$

2.2 RELOCATE BARGE TERMINAL TO LAGO de IZABAL $\ldots \ldots \ldots \ldots \ldots \ldots \ldots \ldots \ldots \ldots .9$

2.2.1 Construct Barge Terminal on North Shore $\ldots \ldots \ldots \ldots \ldots \ldots \ldots \ldots \ldots \ldots \ldots \ldots$

2.2.3 Dual Terminal Facilities on North and South Shores of Lago de Izabal $\ldots \ldots \ldots \ldots \ldots \ldots$

2.3 SURFACE TRANSPORT AND POTENTIAL MODIFICATIONS $\ldots \ldots \ldots \ldots \ldots \ldots \ldots \ldots \ldots 10$

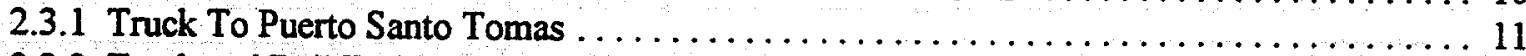

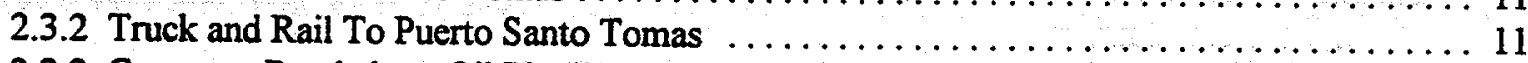

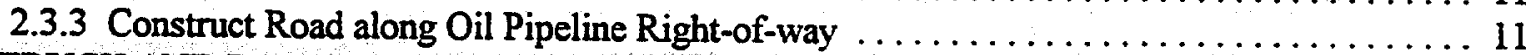

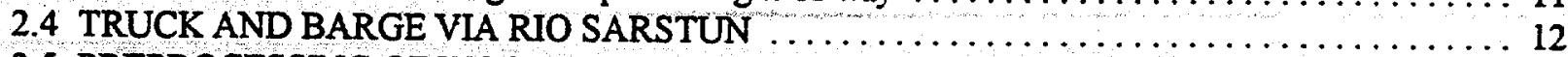

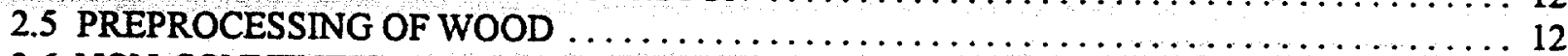

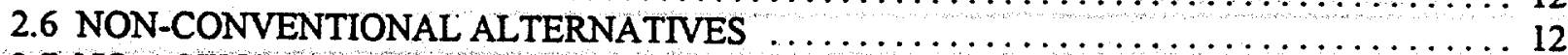

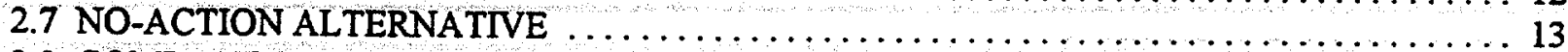

2.8 COMPARISON OF CONSTRAINTS AND IMPACTS OF THE PROPOSED ACTION AND ALTERNATIVES

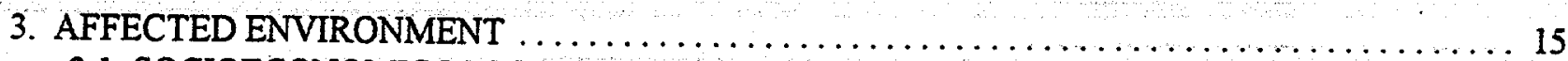

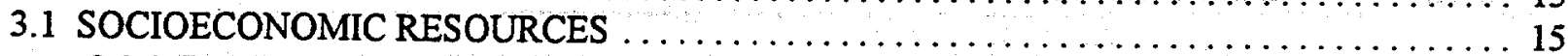

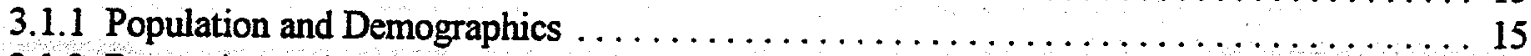

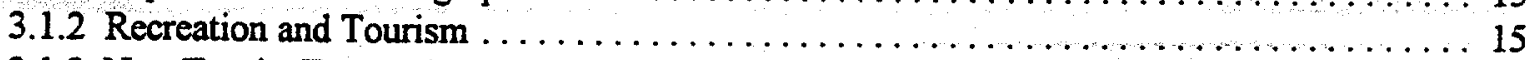

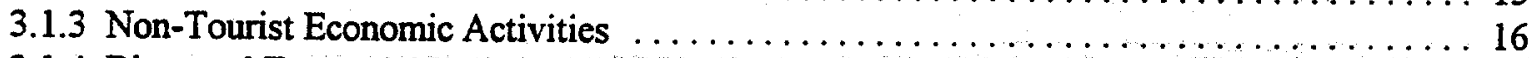

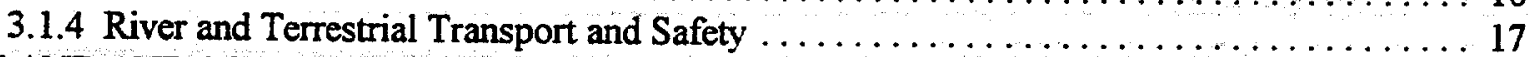

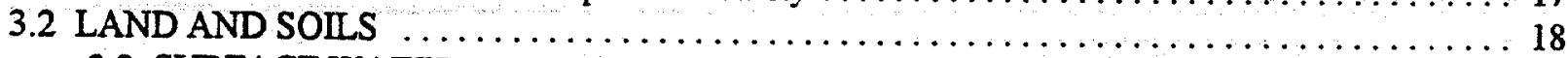

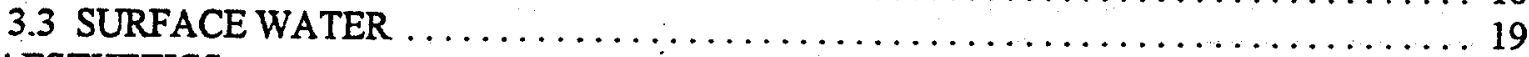

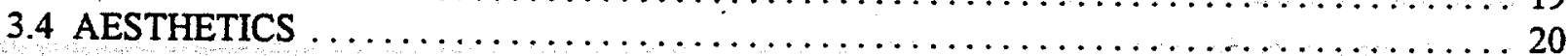

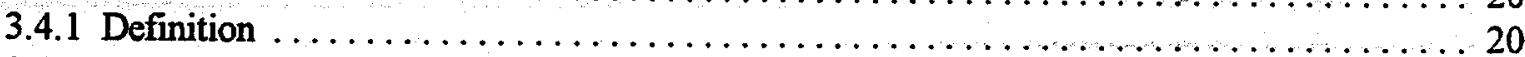

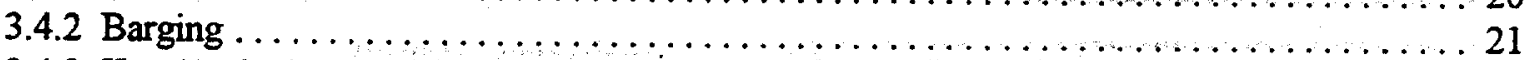

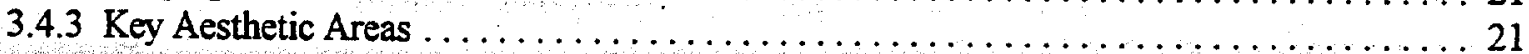

3.4.3.1 Park Intensive Use Zone and Rio Dulce Bridge Area $\ldots \ldots \ldots \ldots \ldots \ldots \ldots \ldots 21$

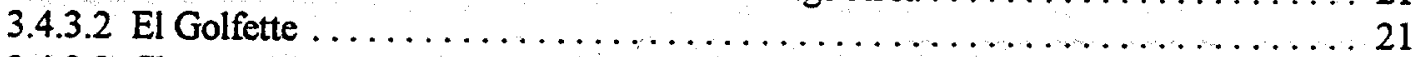

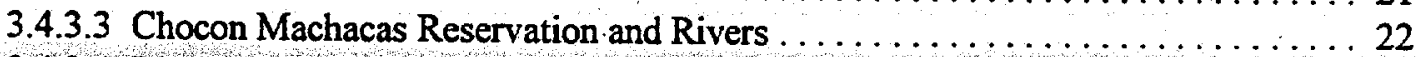

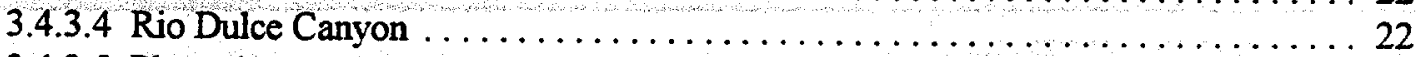

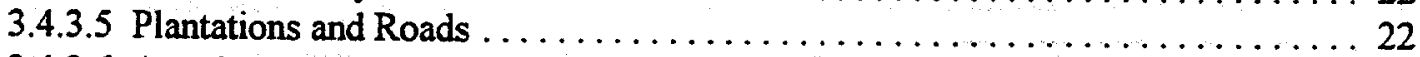

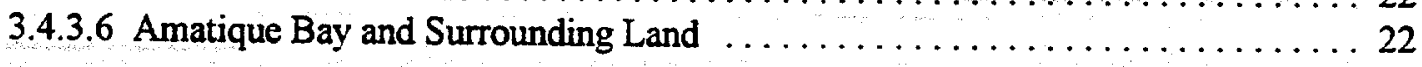




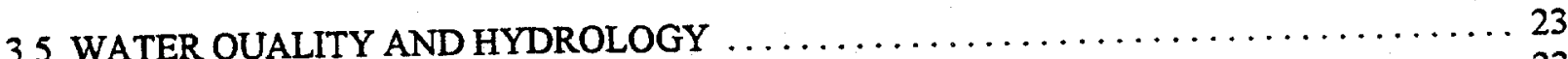

.

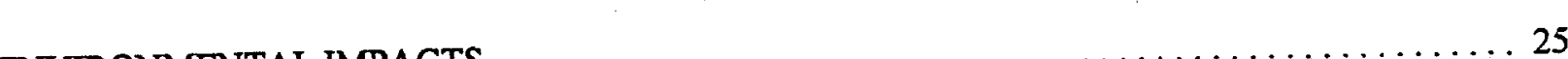

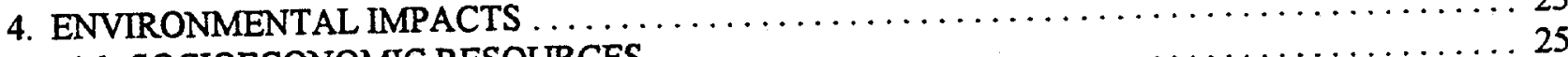

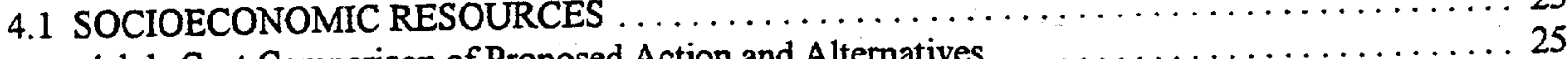

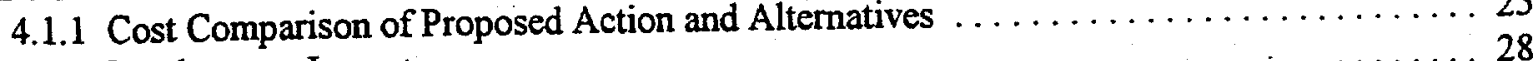

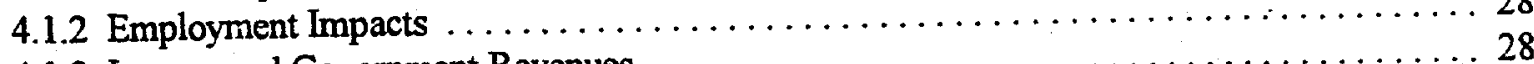

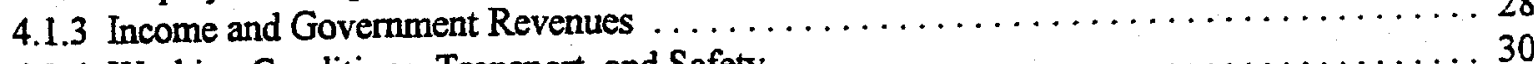

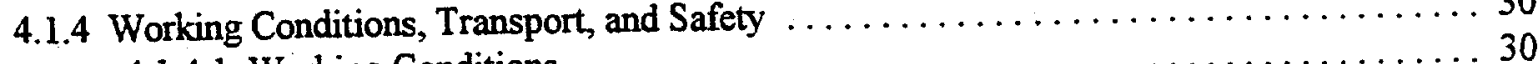

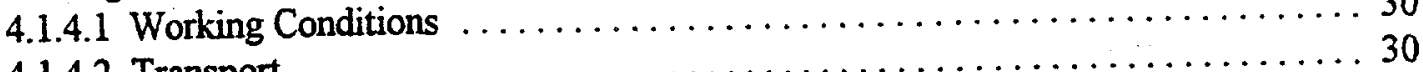

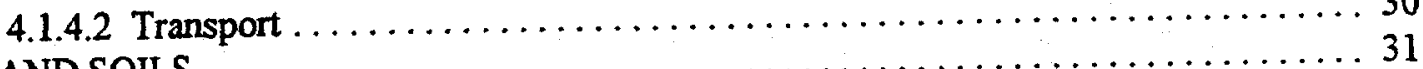

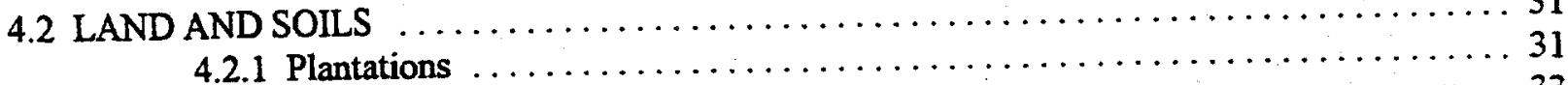

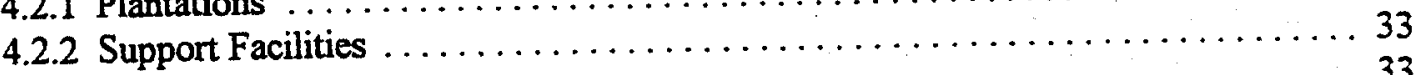

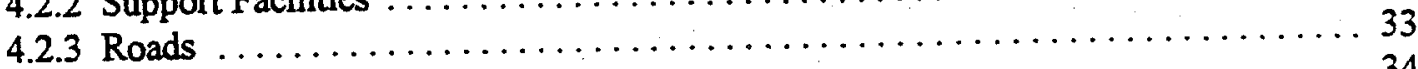

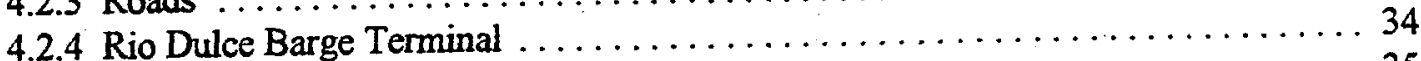

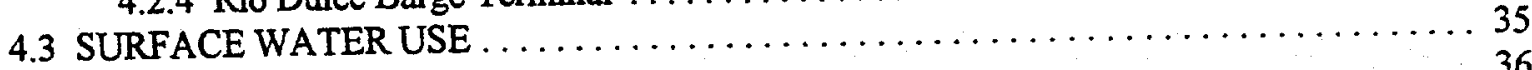

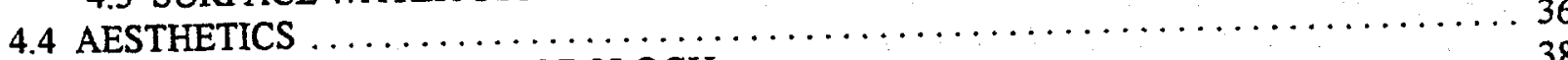

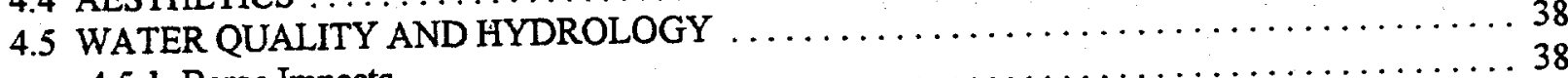

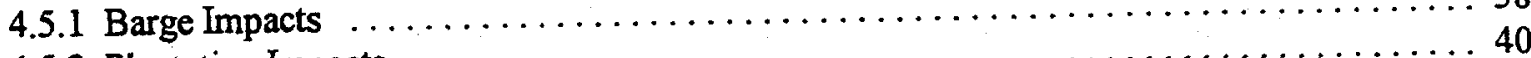

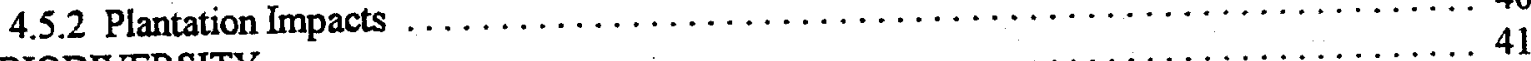

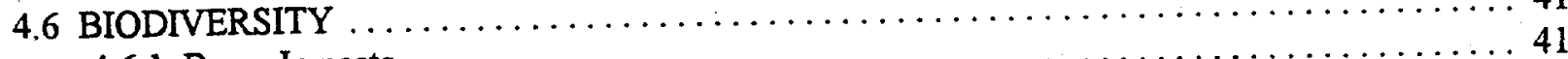

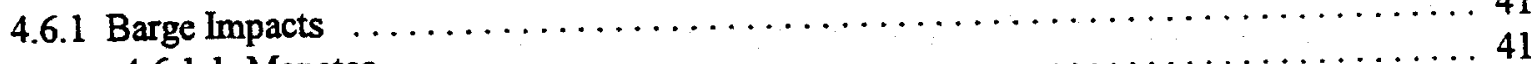

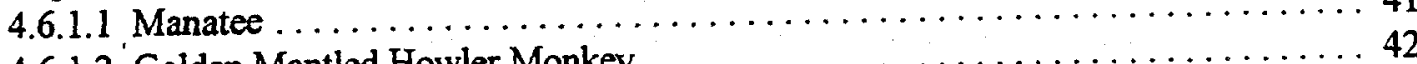

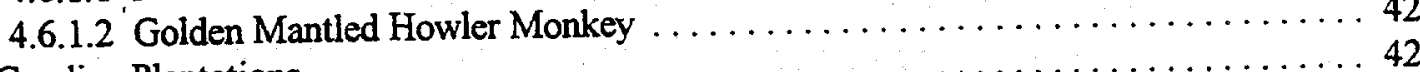

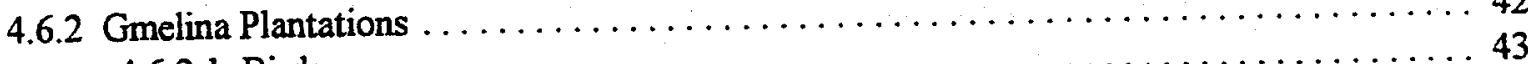

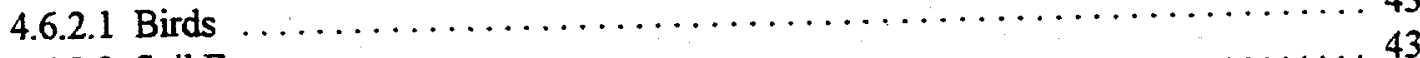

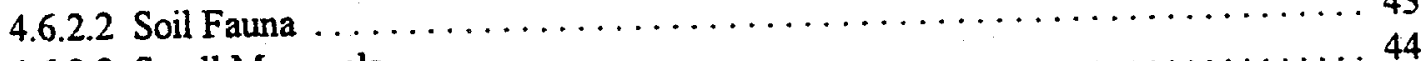

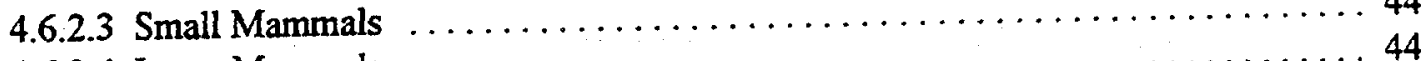

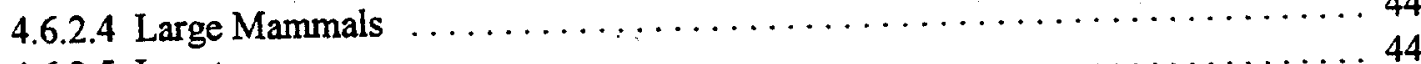

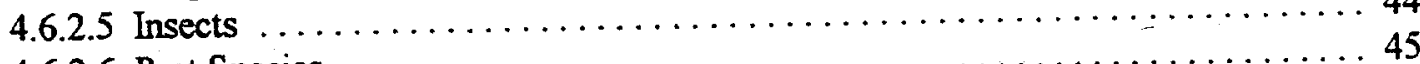

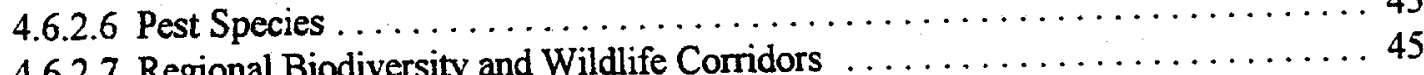

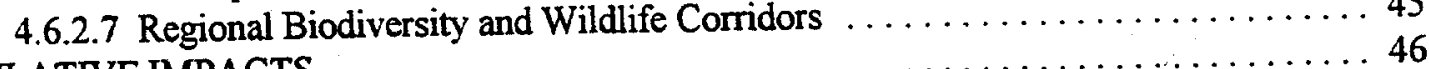

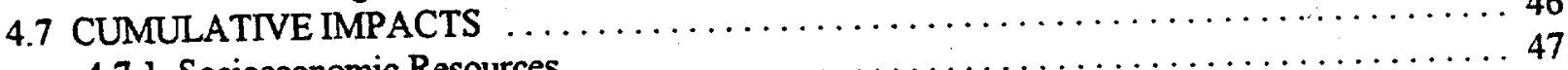

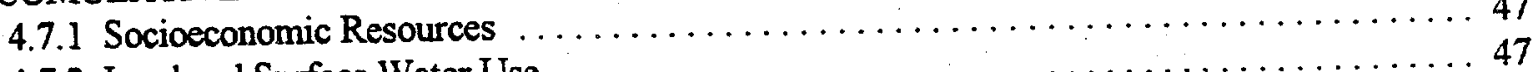

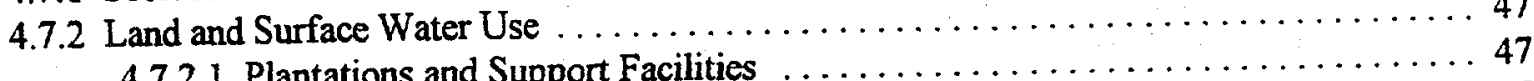

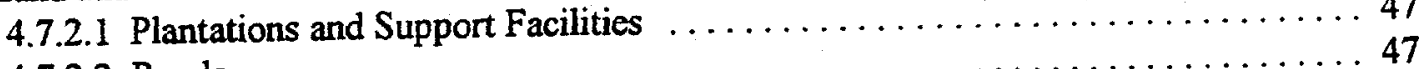

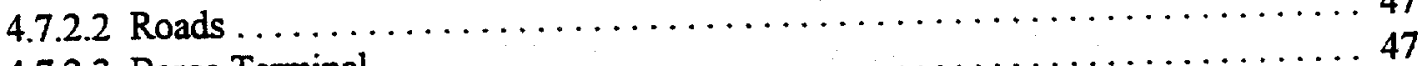

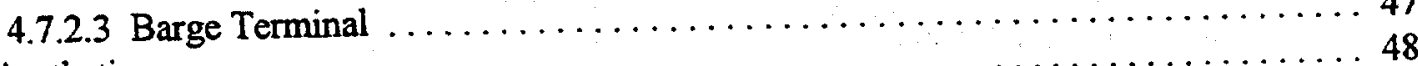

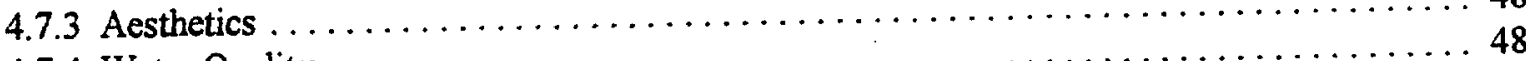

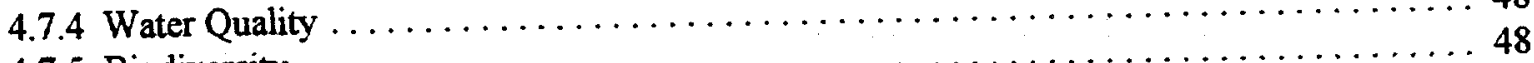

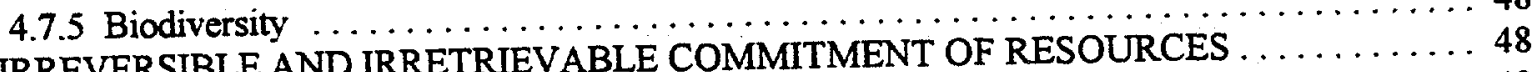

4.8 IRREVERSIBLE AND IRRETRIEVABLE COMMITMENT OF RESOURCES ........48

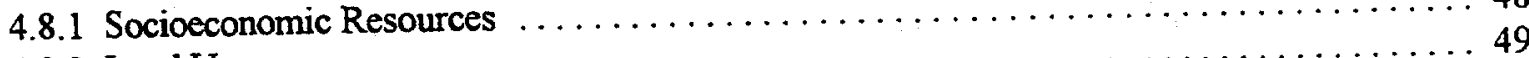

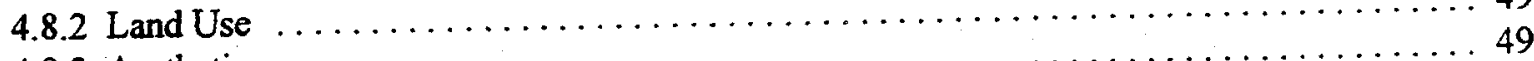

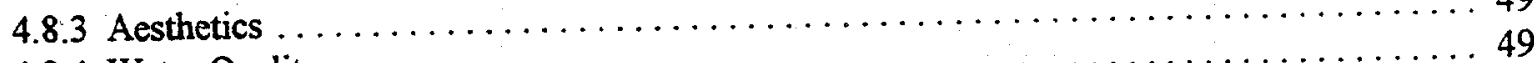

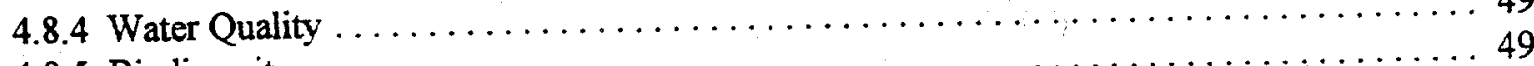

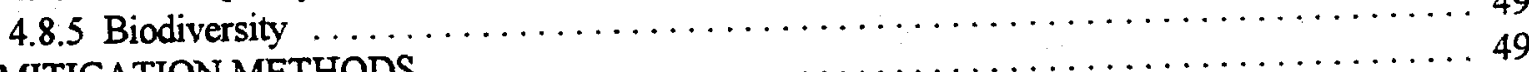

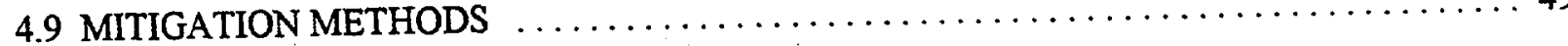




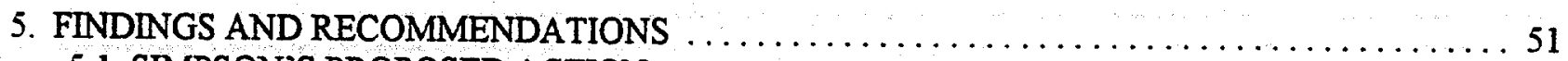

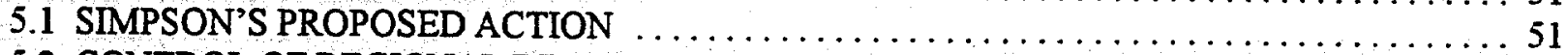

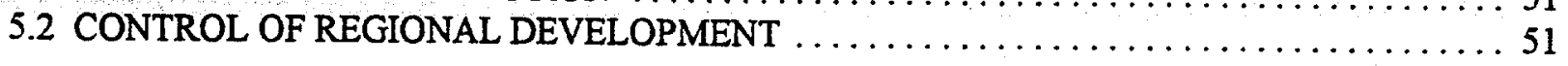

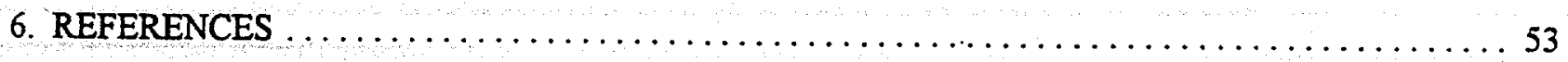

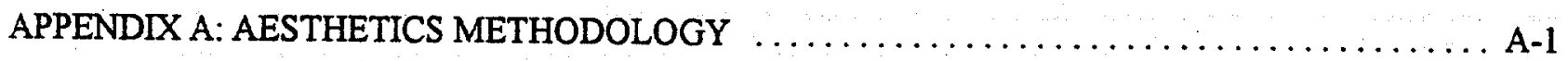




\section{LIST OF FIGURES}

Figure 1. Map showing locations of Simpson's gmelina plantations $\ldots \ldots \ldots \ldots \ldots \ldots \ldots \ldots 2$

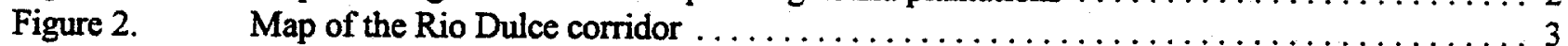

Figure 3. $\quad$ Projected tourism in Izabal $\ldots \ldots \ldots \ldots \ldots \ldots \ldots \ldots \ldots \ldots \ldots \ldots \ldots \ldots \ldots \ldots \ldots \ldots$

\section{LIST OF TABLES}

Table 1. Identification and comparison of alternatives $\ldots \ldots \ldots \ldots \ldots \ldots \ldots \ldots \ldots$

Table 2. Estimated urban and rural population in Izabel $(1990$ and 1995$) \ldots \ldots \ldots \ldots \ldots \ldots$

Table 3. Simpson's comparative cost analysis of the proposed action and road transport to Puerto

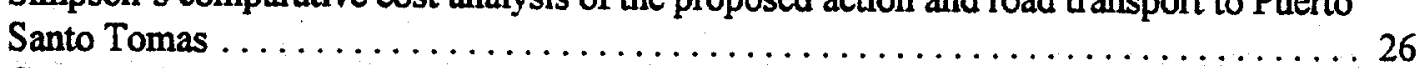

Table 4. Comparative cost analysis of the proposed action and truck transport to Puerto Santo

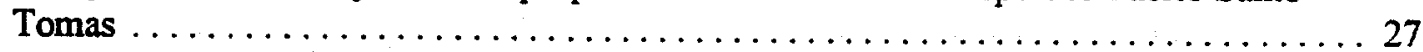

Table 5. Projected direct and indirect Simpson employment under current total plantation area and $\begin{array}{ll}\text { Table } 6 . & \text { potential plantation area due to expansion } \ldots \ldots \ldots \ldots \ldots \ldots \ldots \ldots \ldots \ldots \ldots \ldots \ldots \ldots \ldots \ldots \ldots \ldots \ldots \ldots \ldots \ldots \ldots \ldots \ldots\end{array}$ 


\section{EXECUTIVE SUMMARY}

\section{INTRODUCTION}

The Rio Dulce National Park is one of Guatemala's major environmental assets. The park contains the remaining remnants of an eastern Guatemalan tropical rainforest which has good but fast deteriorating value for the development of the ecotourism industry. The governmental objective for the region as stated in the Master Plan for the park is ecotourism development and protection of biodiversity. The decisions to be made concerning the long-term, sustainable use of the natural resources of the Rio Dulce region appear to be directed by existing environmental laws and the Rio Dulce Master Plan. However, the wording of these instruments is ambiguous and lacks specific definitions and criteria for making necessary determinations. This, in combination with lack of enforcement in the region, has led to extensive disparity in interpretation of the laws and uncontrolled, conflicting actions by individuals and organizations.

This environmental impact assessment (EIA) addresses a proposal by Forestal Simpson, Ltda. (Simpson) for transporting harvested gmelina trees from the Rio Dulce region to a paper pulp mill at Pasadena, Texas in the United States. The proposal calls for moving the logs by truck from plantations located both north and south of the Rio Dulce to a proposed barge terminal that would be constructed at Ensenada Nana Juana, near the Rio Dulce Bridge. The proposed barge terminal would be located on the south shore of the river, within the "intensive use zone" of the Rio Dulce National Park. Under the Simpson proposal, one barge per day would be loaded with logs and moved by tug via the Rio Dulce to a barge staging facility in Bahia de Amatique, a distance of approximately $56 \mathrm{~km}$. Here an ocean-going, semi-submersible carrier barge would take on six loaded barges and transport them to the United States. Although the proposed action provides the focal point for the assessment, the broader purpose of the EIA is to assist the Comision Nacional del Medio Ambiente (CONAMA) in decision-making concerning the sustainable future development of the Rio Dulce region.

\section{KEY ENVIRONMENTAL ISSUES}

The key environmental issues identified and addressed in the EIA are related to gmelina plantation operations and the construction and operation of the barge terminal within the Rio Dulce National Park. Due to a lack of sufficient, reliable baseline information, a thorough assessment of all potential impacts was not possible. However, the assessment team focused on the six key environmental resource areas addressed below; employed a number of assumptions based on available information; and attempted, to the extent possible, to provide comparative information concerning direct, indirect, and cumulative impacts of the proposed action and viable alternatives. The most significant issues related to the six resource areas are summarized briefly in the following sections.

Socioeconomic Resources. Simpson has invested approximately $\$ 20$ million in the local economy for the establishment of gmelina plantations totaling about $7500 \mathrm{ha}$. Their plan is to spend another $\$ 5.4$ million on the construction of the barge terminal with associated support facilities, and establishment of about 2500 ha in additional gmelina plantations. Subsequent spending will total \$6 million annually (\$4 million for harvesting and \$2 million for replanting). This level of local investment compares with about $\$ 10$ million currently spent annually by tourists in the Rio Dulce corridor. Expectations are that the number of tourists and level of spending will increase significantly in the next ten years.

Simpson plans to harvest about 10,000 ha of gmelina annually and plans to employ about 1200 full-time workers. Another 1200 jobs are expected to be created indirectly (e.g., suppliers of parts, mechanics, clerks, 
etc.), raising total estimated employment related to Simpson operations to 2400 . Comparatively, it is estimated that direct and indirect employment from tourism currently totals about 1250 jobs. However, there is tremendous potential for development of tourism in the Rio Dulce region which would significantly expand tourism related employment levels.

Simpson maintains that barge transport of gmelina would be marginally viable if the price of gmelina is assumed to be $\$ 37.50$ per ton. Several alternative methods for transporting the gmelina logs to port are considered in the EIA. However, barge transport on the Rio Dulce would be the only option that would both allow harvesting to begin in the necessary time frame and would allow Simpson to operate on a "break even" economic basis.

Another key transportation issue related to the Simpson proposal would be the additional congestion resulting from approximately $100 \mathrm{log}$ trucks traversing the already congested area of Fronteras and the Rio Dulce Bridge two times per day. The trucks could impact the development of tourism in the area. Because they would be moving throughout the day, aesthetics (visual and noise), safety, and possibly biodiversity could be affected. Because the barge terminal would be constructed on the south shore of the Rio Dulce, the additional truck traffic on the bridge would occur when harvesting is underway on the north side of the river.

Truck congestion in and around the Rio Dulce bridge along with the environmental impacts and accidents that are likely to occur could be avoided with the use of a dual barge terminal system in Lago de Izabal. With this system, the log trucks would be able to access the barge terminal site on the same side of the river as the plantations that were being harvested. Travel time would be reduced and the additional congestion at the Rio Dulce bridge would be avoided. The technical feasibility of this alternative should be thoroughly investigated.

Land and Soils. Gmelina plantations and support facilities will soon occupy approximately 10,000 ha of land in the Rio Dulce region, and there is potential for doubling the size of the operation. Almost all of this land is devoted to the growth of a non-native monoculture. There are some advantages in the use of land for tree plantations rather than open pasture or farmland. However, there are several environmental disadvantages to strict monocultures which exclude the growth of natural vegetation. Therefore, management practices that include the interspersal of natural vegetation corridors among the plantations should be implemented. Such practices would provide variety in the landscape, allow natural processes important to the ecosystem to become reestablished, and provide habitat and routes for movement of native wildlife.

Most of the plantation land has been converted from cattle pasture, and some from subsistence agricultural uses. The effects of the plantations on the soil are generally considered environmentally positive. The soils become less compacted and better structured with the combined action of initial site preparation, tree root penetration, and increased soil organic matter. Over time, the plantations should provide a gradual increase in organic matter, a slight rise in $\mathrm{pH}$, increased diversity of soil microbiota, and a decrease in water runoff.

Construction of the barge terminal would occupy several acres on the shore of the Rio Dulce and would include a $200 \mathrm{~m}$ barge canal to be constructed inland from the shoreline. The proposed location has been designated as an intensive use zone by the Master Plan for the Rio Dulce National Park, and is already heavily degraded by previous uses. However, construction of the barge terminal would constitute a permanent change in the shoreline which would essentially preclude possibilities for natural reclamation of the site or other less intrusive uses. Simpson would replant a vegetation buffer at the edge of the water (with the exception of the barge canal entrance) to provide a visual and sound buffer. However, this would require considerable time to mature and its effectiveness (particularly for sound buffering) is not guaranteed. 
Surface Water Use. Under the Simpson proposed action, the Rio Dulce and Bahia de Amatique would be used for the staging and movement of barges loaded with gmelina logs. Barge traffic along the river would start with two single barge passes per day (outbound loaded and return empty) on weekdays. If wood production increases substantially, four single barge passes or two double barge passes may become necessary.

Some concerns have been raised related to the possible effects of the relatively large barges ( $10 \mathrm{~m} \mathrm{by} 60 \mathrm{~m})$ on the numerous cayucos and other small vessels on the river, especially in the narrow sections of the river near the Rio Dulce Bridge and in the Canyon. By maintaining and widely publicizing a regular schedule for the daily round-trip, and through the conservative, aesthetically conscious use of navigational aids, the presence of the barges should pose no serious hazard and quickly become a routine occurrence on the river. However, navigating the barge/tug combination through the sharp, narrow turns of the Canyon would provide a challenge for any tug captain and should be carried out only after thorough training and at very slow speeds

Aesthetics. Assessment of potential aesthetic impacts are based on observed levels of human activity, Master Plan guidance, and assumed expectations of ecotourists. Two of six locations evaluated were determined to have potential for significant impacts under the proposed action.

At the proposed barge terminal site in the park intensive use zone, significant aesthetic affects would result principally from the views of the large commercial barges in a fishing/tourist area; the cutting of a $30 \mathrm{~m}$ notch in the trees along the edge of the river (site is heavily impacted); possibly the smell of exhaust fumes in the immediate vicinity; and the noise of $100 \mathrm{log}$ trucks per day, the equipment at the terminal, and the loading of logs into the metal barges.

In the Rio Dulce Canyon, aesthetic impacts would result from the passage of the large barges through a nationally important scenic area. The barges would be out of scale and present strong viewer focus in this narrow section of the river. The sound of the tug could be magnified because of the high rock walls. Under the proposed action, these impacts would be limited to brief periods during two passes per day. Necessary navigational markers would conflict with the rustic setting.

Water Quality. The water quality of the Rio Dulce is currently being degraded by uncontrolled development and rapid population growth along its shores, particularly in the vicinity of the Rio Dulce Bridge. Bahia de Amatique is also surrounded by increasing population and is heavily traveled by commercial shipping. With proper management practices and establishment of navigation and spill response measures, there should be no noticeable additional impacts to the overall water quality of the river or the bay from the proposed action. However in the lagoon at Ensenada Nana Juana, there is intense pressure from the growth of population and commercial activities. Potential exists for the concentration of pollutants in the lagoon because of relatively poor water circulation with the main river channel. This in combination with the regular churning and resuspension of sediments by tug propellers could present a significant water quality problem. The situation should be monitored closely.

Biodiversity. The EIA team found no evidence that Simpson barging operations on the Rio Dulce would significantly impact any species of fish or other aquatic biota. The assessment focuses on two threatened species of the region, the manatee and the terrestrial golden mantled howler monkey. The local populations of manatees appear to be precariously small, making the loss of one animal a significant event. The manatee is slow moving; however, their natural avoidance of human activity and preference for the shallow, near-shore environment would make barge/manatee encounters rare. Furthermore, the slow speeds at which the barges would travel and the vibrations from the tug propellers should provide adequate warning and escape intervals. Of more concern would be the unproposed use of the Chocon Machacas Biotope and the Rio Chocon 
Machaca or other tributary streams for plantation-related activities. Such activities would pose high risks to the local manatee population.

One small population of golden mantled howler monkeys inhabit an area in the intensive use zone of the national park known as the Marimonte Reserve. This is slightly east of the proposed barge terminal location. The activity of the tugs, the truck traffic, the sounds of logs being moved, and the movement of barges nearby would add to existing water and land traffic now surrounding the isolated habitat. Any effects would likely be neutral or negative. However, these may be lost in the cumulative intrusion of development on the monkey population.

With respect to plantation operations, experience has shown that biodiversity in the vicinity of large plantations can be enhanced by inclusion of areas of local tree species, allowing growth of some understory, and allowing natural vegetation to take over along fence rows and natural drainage areas. Such practices should be implemented in the Rio Dulce region to promote biodiversity and ecotourism which is based largely on the presence of indigenous vegetation and wildlife.

\section{KEY FINDINGS AND CONCLUSIONS}

Rapid population growth and uncontrolled commercial and private development, some of it resulting from the tourist industry, are continuing to exert pressure on the environmental resources and the natural beauty of the Rio Dulce region. In order to halt and possibly, to some extent, reverse the deterioration of the unique resources, well defined, realistic controls must quickly be established and enforced. The Master Plan for the Rio Dulce National Park can provide the basis for defining controls and developing specific criteria for making determinations concerning appropriate uses of the region's resources. In that regard, both gmelina plantations and ecotourism provide significant and desperately needed economic benefits to the Rio Dulce region in the form of revenues and jobs. Both can also be carried out in ways that better provide for controlled economic development, while protecting and promoting the well-being of the environmental resources that make the area unique.

In the present case, the construction of a barge terminal inside the land use zones of Rio Dulce National Park would set a precedent contrary to the intent of the Master Plan. It would constitute an irreversible commitment of land that would preclude natural reclamation or establishment of less intrusive uses. Additionally, it would impose a permanent change to the shoreline which would add incrementally to the aesthetic, water quality, congestion (safety), and biodiversity impacts of current uncontrolled commercial development of the area. If properly controlled, the presence of limited barge traffic on the river would not pose significant impacts.

Of the alternatives considered, relocating the proposed barge terminal to Lago de Izabal appears to provide the best combination of economic viability and mitigation of many of the deleterious impacts associated with the proposed construction and operation of the terminal at Ensenada Nana Juana. The use of a two-site (north and south shore) system in Lago de Izabal with some transportable equipment, would simplify transport of the logs to the terminal and would avoid virtually all of the potential impacts of introducing the barge terminal and truck traffic into the protected areas of the national park. A study should be initiated to provide a better understanding of the environmental, technical, and economic implications of moving the barge terminal(s) to Lago de Izabal. 


\section{INTRODUCTION}

The Comision Nacional del Medio Ambiete (CONAMA) has requested, through the U.S. Agency for International Development (USAID), that Oak Ridge National Laboratory (ORNL) collaborate with CONAMA staff in conducting an environmental impact assessment (EIA) for the Rio Dulce Protected Area. The purpose is to assist CONAMA in decision-making concerning present and future uses of the natural resources of the region. The focal point of the assessment is the proposed action by Forestal Simpson, Ltda. (Simpson) to transport the harvests of Gmelina arborea (gmelina) tree plantations (Figure 1) by barge via the Rio Dulce to Bahia de Amatique (Figure 2). From there the logs would be transported to the United States for use in the production of paper pulp. Direct impacts of the action would result from the construction and operation of a barge terminal at Ensenada Nana Juana (Figure 1); hauling the logs by truck to the barge site; and transport of the logs by barge on the river. Indirect/regional impacts of the proposed action would include setting precedents for the use of the Rio Dulce for barge traffic, and for land use within the Rio Dulce National Park. The site selected by Simpson for the barge terminal lies within the Rio Dulce National Park, in a zone designated as "intensive use." This EIA assesses the proposed Simpson activity and viable alternatives.

Under Guatemalan law Simpson prepared an environmental report specifically on their proposed action, but not all possible alternatives. This was required prior to a decision being made by CONAMA on approval of the use of the river for barging. The Simpson report that was submitted to CONAMA in December 1996 is limited in scope dealing only with transport of material on the Rio Dulce. Because of this and a general lack of quantitative background environmental data, the team preparing this EIA had to make numerous assumptions related to comparative costs and potential impacts.

\subsection{PURPOSE AND NEED FOR THE PROPOSED ACTION}

In 1988, Simpson Investment Company agreed to financially support a commitment between Simpson and the San Jacinto Mill in Pasadena, Texas, to establish and grow commercial gmelina tree plantations for supplying 250,000 tons of wood per year for the production of paper pulp. The logs to be delivered would be harvested from plantations established in Guatemala in the area of the Rio Dulce and around Lago de Izabal.

From 1988 to the present time, a total of $\$ 20$ million has been invested in the project. Of this amount, about $30 \%$ has been invested in the purchase and rental of land, purchase of equipment, and construction. Much of the remainder has been used for salaries for approximately 600 employees.

The next phase of the project is the harvesting of gmelina trees, transport of the harvested logs to Bahia de Amatique for shipment to the United States, and reestablishment of the harvested plantations. For transport of the logs to the coast, Simpson has selected barging via the Rio Dulce from a barge terminal to be constructed at Ensenada Nana Juana to an offshore staging platform in the bay near Punta de Manabique

(Figure 2). The staging area would be protected from winds and high seas and would be to the side of the main Puerto Barrios and Puerto Santo Tomas de Castilla Navigation Channel (Forestal Simpson 1996). 


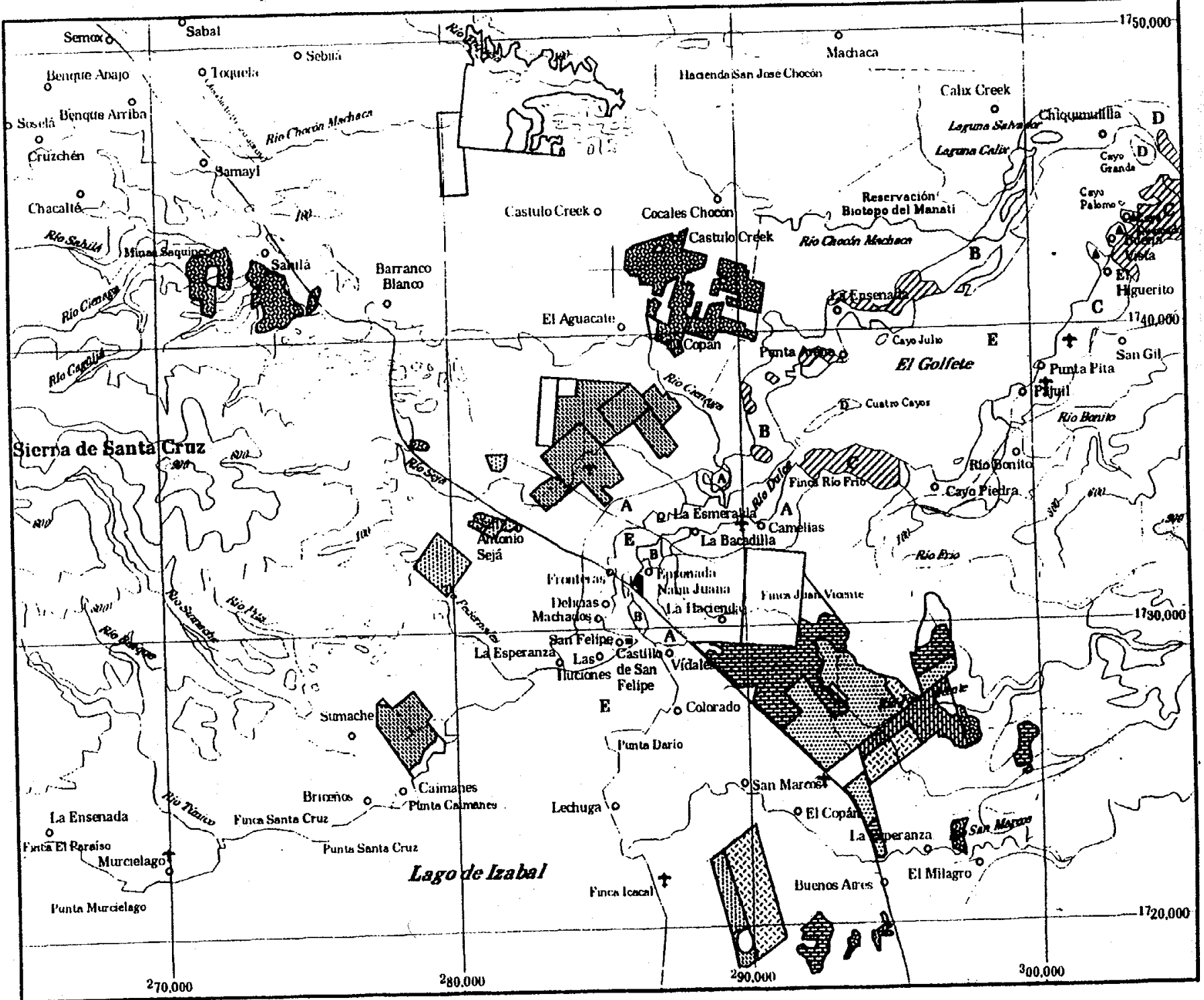

Referencias

1,988

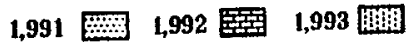
1,994 1,995 $1,996 \square$

Z Zona de us() intensivo

[8] Zona primitıva

[C] Znna de uso especual

[D] Zona de protecrión especial

IE Zona de cursos de agua

EZA Sub zona de recuperacoin

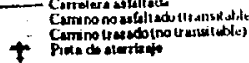
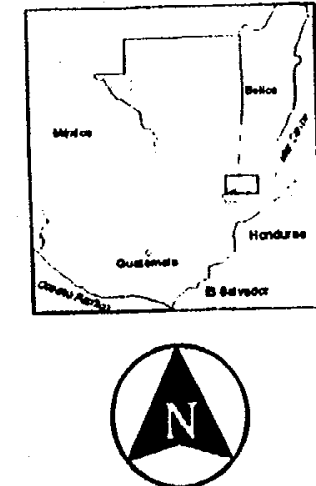

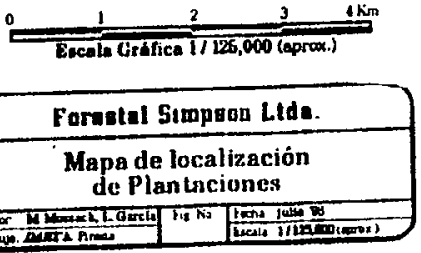

Figure 1. Map showing locations of Simpson's gmelina plantations. 


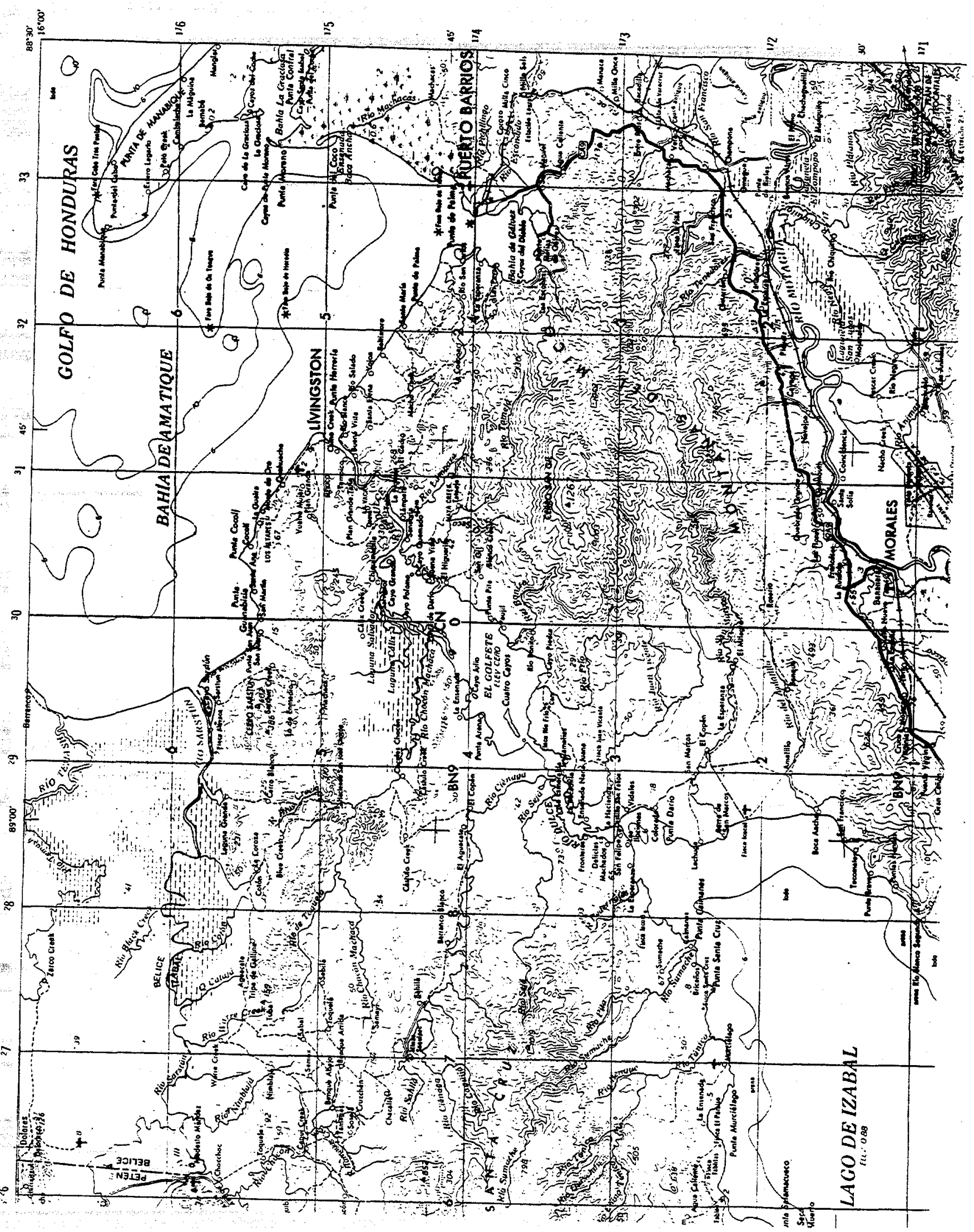

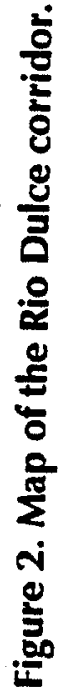




\subsection{BACKGROUND}

The Rio Dulce corridor is one of Guatemala's major environmental assets. The Rio Dulce National Park is an eastern Guatemalan tropical jungle frontier that has good but fast deteriorating aesthetic value for wet tropical rainforest ecotourism. Recreation and tourism are currently the major sources of income and jobs for the area. The governmental objective as stated in the Master Plan for the park is ecotourism development and protection of biodiversity. Recreation and cultural tourism are also important in some areas. Ecotourism differs from these and other forms of tourism, including adventure travel, travel study, etc., in having a much stronger conservation ethic. It attempts to create new economic linkages whereby money generated by the tourist's presence is used to protect and improve the natural resource base. It is a form of sustainable development, provided the carrying capacities of the natural environment are not exceeded (Kangas et al. 1995). Accordingly, the experience of natural environmental conditions and accessible biodiversity are strongly desired aesthetic elements that need to be restored and maintained in most of the Rio Dulce corridor. The deterioration of aesthetics and biodiversity in the corridor are caused by uncontrolled, piecemeal, and concentrated developments within and outside the park. Restoration is a definite need.

The decisions to be made concerning the long-term plans for use of the natural resources of the Rio Dulce region appear to be directed by existing laws and the Rio Dulce Master Plan. These documents, in general terms, call for the protection and development of the region as a national park and a center for ecotourism. However, Simpson began establishing the gmelina plantations approximately eight years ago under a previous administration, at a time when enforcement of environmental laws was not considered a priority. During this same time period, uncontrolled, frontier-type development and destruction of resources has been occurring along the Rio Dulce corridor. Now, the plans by Simpson to begin construction of the barge terminal in 1997, and to begin harvesting and shipment of gmelina trees within a year are adding a new level of urgency to the need for decisions by CONAMA concerning the long-term development of the region.

\subsection{SCOPE OF THE EIA}

Typically EIAs may cover the complete scope of environmental issues, e.g., air quality, water quality, meteorology, geology and soils, ecology, land use, and socioeconomics. However, due to the urgency of the decisions, the scope of this EIA is focused on only those issues related to the proposed action that have the potential to result in significant (direct and indirect/regional) impacts. During the site visit and evaluation of the proposed activities, the following issues were determined by the EIA team to have the greatest potential for significant impacts: aesthetics, biodiversity, land and water use, socioeconomics, and water quality.

The team also identified several potential alternatives to the proposed action, e.g., the relocation of the barge terminal to Lago de Izabal (possibly with limits on the timing and number of barges that would be allowed); hauling the logs by truck to Puerto Santo Tomas via existing roads or a newly constructed road along the oil pipeline right-of-way; a combination of truck and rehabilitated railroad transport to port; truck and barge transport via the Rio Sarstun; preprocessing of wood; and non-conventional alternatives such as transport via cable system or pipeline.

Eacin of the alternatives was subjected to an initial feasibility evaluation. Those that were determined to present a viable alternative or modification to the proposed action are addressed and compared to the proposed action according to their potential impacts. Following a description of the existing environment, the potential direct, indirect/regional, and cumulative impacts of the viable alternatives are assessed and compared to the extent that it could aid in the decision-making process. Additionally, any associated irreversible and irretrievable commitment of resources are described, and possible mitigation measures are identified. 


\subsection{LEGAL AND POLICY FRAMEWORK}

The wording of existing laws and even the Master Plan for the Rio Dulce area is highly ambiguous and lacks specific definitions and criteria for making determinations. This, in combination with lack of enforcement in the region, has led to extensive disparity in interpretation of the laws and uncontrolled, conflicting actions by various individuals and organizations. The result of the confusion is the continuing, widespread devastation of the unique natural resources that were abundant within the last thirty years in the Rio Dulce region. The Simpson proposal considered here is a major commercial activity and poses an added major development issue for the park with potentially far reaching implications. The determination must be made as to whether or not the proposed action is compatible with the park's Master Plan, both now and in the future.

The following statements illustrate a partial history of regulations affecting the Rio Dulce region. All of the examples indicate recognition of the need to protect the park, but do not demonstrate a firm commitment to controlling development in the region.

- 1955 Presidential Declaration: Designated the Rio Dulce watershed as a national park, but without firm guidelines for enforcement

- 1968 , Government Agreement : Established a $1 \mathrm{~km}$ protective buffer around the river, but excluded Lago de Izabal

- 1992, Government Agreement 263-92: Supported forestry, habitation, tourism, and instituted Consejo Nacional de Areas Protegida (CONAP) discretion in decision-making, depending on circumstances and available information

- 1993, Government Agreement 182-93: Established Protective Zones and Prohibitions, but provided no enforceable specifics

Furthermore, the Master Plan for the Rio Dulce National Park provides general guidance for different forms of development, but leaves much open to interpretation. This is illustrated by the italicized terms in the following statements.

- Prohibits intensive agriculture requiring complete clearing.

- Supports establishment of permanent tree crops.

- Protects dense forest areas for howler monkeys.

- Requires $20 \mathrm{~m}$ buffer between habitations and the river.

- Habitations existing before 1991 can be declared legal only if they support tourism, forestry, or silviculture.

The EIA team believes that the current policies concerning the region are ambiguous and contribute significantly to the destruction of the resources and the conflicting plans for development. The conditions in the Rio Dulce region present an immediate and critical challenge for CONAMA and associated environmental agencies as they attempt to establish policies for the restoration and long-term protection of Guatemala's unique natural resources. 


\section{ALTERNATIVES INCLUDING THE PROPOSED ACTION}

Simpson began purchasing land for the establishment and planting of gmelina south of the Rio Dulce in the latter half of the 1980s. Planting began in 1988 on the south side and continued through 1995 except for 1994 (Figure 1). In the early 1990s, Simpson bought land on the north shore of Lago de Izabal and entered into numerous land lease arrangements on the north-side of the Rio Dulce. North-side plantings began in 1993 and continued through 1996. Currently, Simpson has about 7500 ha of land planted with gmelina both on the south and north side of the Rio Dulce, with an additional 1500 ha of land planned for future gmelina establishment. The total plantation area will be approximately $10,000 \mathrm{ha}$ and will initially produce about 250,000 tons (green) of gmelina (Forestal Simpson 1996). This production will meet about $18 \%$ of the annual wood requirements for the San Jacinto pulp mill. However, the San Jacinto mill has the capability to meet up to $40 \%$ of their wood requirements from hardwood chips (Mussack 1996). The mill is located in Pasadena Texas and will be accessed through the port of Galveston.

Although not discussed in their environmental impact report, it is assumed that Simpson will begin harvesting operations with the older trees on the south side of the Rio Dulce. Harvesting will begin during the later half of 1997 , after the proposed barge terminal is completed. Harvesting will likely continue on the south-side through 1998 and into 1999. Harvesting on the north-side of the Rio Dulce and Lago de Izabal will likely begin sometime during 1999. Superior clones of gmelina will be reestablished after the initial harvest. The superior clones will most likely result in annual production in excess of 250,000 tons after initial harvests.

The remainder of this section provides a description of the proposed action to transport the harvested logs on the Rio Dulce as well as alternatives to the proposed action. Section 2.1 outlines the proposed action including the location of the plantation sites, movement of harvested wood to the barge terminal, construction and operation of the barge terminal, movement of loaded and unloaded barges on the Rio Dulce, and barge transfer operations in the Bahia de Amatique. Sections 2.2 through 2.6 describe potential alternatives to the proposed action. The last subsection provides a summary of the technical and economic constraints to implementing these alternatives as well as potential significant impact pathways.

\subsection{THE PROPOSED ACTION: TRUCK AND TRANSPORT LOCS VIA RIO DULCE}

This description is based on the Forestal Simpson environmental report (1996). Simpson proposes to fell the plantation trees using chainsaws. After felling, the trees will be de-limbed, de-barked, and bucked into $2.5 \mathrm{~m}$ lengths in the field. The $2.5 \mathrm{~m}$ logs will then be moved to a landing area where they will be loaded onto trucks for transport to the barge terminal. Harvesting operations are expected to take place year-round subject to weather, accessibility, and site conditions. The chainsaw crews as well as the trucks and operators for hauling the logs to the terminal will be contracted on a need basis. The typical truck has a haul capacity of about 10 tons and will be driven on a combination of dirt/gravel and paved roads to reach the proposed barge terminal location-Ensenada Nana Juana (Figure 1). Total truck haul distances from the south-side sites will be short and average about $4-6 \mathrm{~km}$. Transport distances to the proposed barge terminal site from the north-side sites of the Rio Dulce will be 2 to 4 times longer on average. Transport routes on the north-side will require driving through the town of Fronteras and crossing the two-lane Rio Dulce bridge. The relatively small load carrying capacity of the trucks means that about 25,000 trips to the barge terminal site will be required each year or 100 trips each day, 5 days per week. 
The proposed barge terminal site, Ensenada Nana Juana (Figure 1), is on the south side of the Rio Dulce and just east of the Rio Dulce bridge in a national park zone designated as "intensive use." The Simpson environmental report (1996) states that the site was selected for a number of reasons:

- the area was highly impacted because of previous uses (i.e., the oil pipeline, bridge, and road construction staging areas);

- the area was not considered to be environmentally sensitive;

- the site has sufficient vegetation that will serve to muffle noise and block some land and water views of the barge loading operations;

- the Ensenada is protected from winds and main Rio Dulce channel currents;

- the area is accessible with good roads and has electric power;

- the land where the proposed barge terminal is to be constructed is legally registered; and

- a permit for use of the shoreline buffer is in place through the Oficina de Control de Reservas de la Nacion (OCREN).

All shoreline within the Rio Dulce National Park is owned by the Government of Guatemala. Permits to use the shoreline must be obtained through OCREN.

The plans for the barge terminal site call for the construction of a canal approximately $200 \mathrm{~m}$ long, $12 \mathrm{~m}$ wide, and $3.5 \mathrm{~m}$ deep (Forestal Simpson 1996). The canal would have a northwest to southeast orientation and would cut through the 100 meter government-owned shoreline buffer. On either side of the canal there would be a concrete patio where moveable grapple cranes would be used to off-load the trucks. Off-loading would be expected to take 15 minutes for per truck. Eight trucks can be unloaded per hour (four on each side of the canal). Trucks would remain in the barge terminal area for about 30 minutes.

The canal would be designed to accommodate a standard Mississippi river hopper barge. These barges are approximately $59.4 \mathrm{~m}$ in length, $10.7 \mathrm{~m}$ in width, and have a draft ranging from about 0.5 to $2.7 \mathrm{~m}$ depending on the load. The depth of the barge hold is $3.9 \mathrm{~m}$. Although the carrying capacity of this type of barge is rated at 1500 tons, the low density of gmelina logs reduces the capacity to a maximum of 1200 tons when fully loaded or topped-off (Bray 1996). Simpson plans to top-off the load in the Bahia de Amatique. The barges in the canal would be loaded to the height of the hold or about 900-1000 tons. A 900-1000 ton load translates into a barge draft of about 1.8-2.0 m (Forestal Simpson 1996).

As noted above, eight trucks can be off-loaded each hour. This means that filling a barge to $900-1000$ tons would require 11 to 12 hours. Simpson plans to load the barges during the daylight hours. The loaded barge would then be moved out of the canal into the bay and an empty barge moved into its place. The loaded barge would be pushed down the Rio Dulce during early moming on the following day. This trip would take approximately 7.5 to 8.5 hours. An empty barge would then be pushed up the Rio Dulce during the late afternoon and early evening requiring 6.5 to 7.5 hours.

The large size of the barges would make it possible to limit the number of trips down the Rio Dulce to approximately $250-280$ per year or slightly more than 5 round trips per week on average. The tug is approximately $18 \mathrm{~m}$ in length and $5.5 \mathrm{~m}$ wide, and has an operating draft of $1.8 \mathrm{~m}$. It is powered by two 300 $\mathrm{hp}$ diesel engines. The tug and one barge would have an overall length of $78 \mathrm{~m}$ and $10.5 \mathrm{~m}$ in width. The operating draft of the tug/barge tow would be $1.8-2 \mathrm{~m}$ when loaded to $900-1000$ tons. The draft of the tug and barge could exceed the minimum depth at the bar in the mouth of the Rio Dulce at low tide and perhaps the depth of the lagoon at the terminal site. Simpson has stated no plans for dredging the bar or the lagoon, and the Simpson environmental report indicates that limiting the barge load to 1000 tons will allow passage over the shallows. The potential exists for the disturbance of bottom sediments by the tug propeller at both 
locations. The minimum depth at the sand bar is $1.7 \mathrm{~m}$ with the average depth of the Rio Dulce assumed to be about $3 \mathrm{~m}$.

Once through the bar, the tug would push the barge another $19 \mathrm{~km}$ to a point southeast of Punta de Manabique. The total trip distance from Ensenada Nana Juana is $56 \mathrm{~km}$. At this location Simpson plans to have a permanently moored transfer deck barge equipped with two knuckleboom grapple loaders, one on each side of the deck. The river hopper barges would be transferred to a submersible, ocean-going; barge carrier for transport to Galveston, Texas. The permanently-moored, transfer deck barge would be used to top off the river barges to reach full capacity once they are secured onto the ocean barge-carrier ship. The ship would transport 6 loaded barges and return with empty barges (or barges loaded with some cargo).

The EIA team identified four issues associated with Simpson's proposed action that have potential to affect socioeconomic, land and water, aesthetics, and biodiversity. These are:

- the proposed location for the barge terminal and its impact on aesthetics, land use, water quality, and biodiversity,

- barge traffic on the Rio Dulce and concerns for safety and diminished aesthetics,

- increased congestion on the Rio Dulce bridge and impact on tourism and aesthetics, and

- the proposed transfer barge operations in the Bahia de Amatique.

The alternatives discussed below specifically address these issues.

\subsection{RELOCATE BARGE TERMINAL TO LAGO de IZABAL}

The construction of a barge terminal within the confines of the Rio Dulce National Park would be precedent setting and would also raise a number of environmental concerns and potential associated impacts on existing tourism and potential ecotourism. The three alternatives below specifically address the proposed barge terminal site location; however, technical feasibility of relocating the barge terminal was not addressed by the EIA team.

\subsubsection{Construct Barge Terminal on North Shore}

This alternative involves relocating the barge terminal from Ensenada Nana Juana to the northern shoreline of Lago de Izabal. As shown in Figure 1, Simpson has a gmelina plantation on the north shore of Lago de lzabal near Caimanes. Access to this area is currently by boat or by unimproved road connecting to Antonio Seja or Fronteras. Road distance from the shoreline to Antonio Seja or Fronteras is approximately 5 to $6 \mathrm{~km}$.

Since this Simpson-owned property lies outside the use zones of the national park boundary, conventional barge terminal facilities could be constructed. The construction would involve dredging of the lake near the shoreline and building a dock and patio for loading. Mooring cells would also be required for barge tie-up. In addition, roads would have to be greatly improved to facilitate year-round access to the terminal, and provisions for power supply would have to be made. This area is under the jurisdiction of Livingston, which has considered improving the roads here.

The advantages of this alternative, if technically feasible, would be that it would relocate the barge terminal away from the intensive use zone of the national park. It would require less expensive construction and it would not require the building of a canal into the shoreline. Revenue from the sale of the currently proposed 
site could be used for construction of this facility. However, reaching the terminal from the south-side plantation sites would still require use of the Rio Dulce bridge for movement of logs.

\subsubsection{Construct Barge Terminal on South Shore}

The technical feasibility of this alternative would depend on acquiring a site on the south shore of Lago de Izabal and gaining road access to the site. In their environmental impact report, Simpson discusses the possibility of locating a dock on the south side of Lago de Izabal. Sites in the area south of the Rio San Marcos (Figure 1) were rejected because access would be difficult. Specifically, the access roads would have to upgraded and a portion of the road where it crosses the Rio San Marcos would have to be reconstructed. Moreover, these sites lack electricity and would require the extension of power lines. Simpson also rejected lands north of the Rio San Marcos on the south side of Lago de Izabal because they are privately held and owners are unwilling to sell. Public access to these sites is also a problem. In addition, all sites above and below the Rio San Marcos tend to be swampy which would complicate the construction of a dock facility. The shallow lake depths that are associated with these sites mean that extensive dredging would have to be done to allow $1.8 \mathrm{~m}$ draft barges to tie-up. However, revenue from the sale of the proposed terminal site could be used to acquire a south shore site. Reaching the terminal from the north-side plantation sites would require use of the Rio Dulce Bridge.

\subsubsection{Dual Terminal Facilities on North and South Shores of Lago de Izabal}

The movement of 250,000 tons of gmelina down the Rio Dulce requires nearly $250-280$ barge trips and 25,000 truck trips (10-ton loads) to the barge terminal site each year. Avoiding truck shipments on weekends would mean that as many as 100 trucks could be passing through Fronteras and crossing the Rio Dulce bridge each weekday when harvesting north-side plantation sites. The dual terminal alternative serves two purposes. First, it relocates the barge terminal from the intensive use zone of the park to Lago de Izabal. And second, it eliminates the necessity of using the Rio Dulce bridge to reach a barge terminal. That is, wood from plantations located on the south-side of the Rio Dulce and Lago de Izabal would use a southern terminal and plantations on the north-side would use a northern Lago de Izabal terminal. If the 5-year rotation schedule could be sequenced such that in years 1 and 2 south-side sites are harvested and in years 3,4 , and 5 northside sites harvested, then much of the equipment (e.g., portable grapple cranes) and investment could be moved to the north or south shore depending on harvesting schedule. This could eliminate some duplication of investment, especially if a transportable barge facility could be used. Furthermore, this alternative would not require the expense of building a canal into the shoreline, and some costs could be recouped from the sale of the Ensenada Nana Juana site. The road access and power availability constraints noted above would also apply here.

\subsection{SURFACE TRANSPORT AND POTENTIAL MODIFICATIONS}

Three alternatives have been identified by the EIA team to avoid use of the Rio Dulce for log transport. These alternatives involve hauling the logs directly to Puerto Santo Tomas; trucking the logs to the railroad near Morales for movement to the port; and constructing a road parallel to the oil pipeline right-of way. The latter two alternatives would require major capital investment and time to implement. All three alternatives would require the use of the Rio Dulce bridge for access to the north-side plantation sites. 


\subsubsection{Truck To Puerto Santo Tomas}

There are two major ports on the Atlantic coast, Puerto Santo Tomas and Puerto Barrios. However, Barrios is privately operated and currently handles most of the country's exports of bananas in addition to some handling of bulk commodities. Approvals would be required to make use of this port, thus Santo Tomas would be the port of choice.

The only near-term alternative that would avoid use of the Rio Dulce and disturbance of the Ensenada Nana Juana would be to haul the logs directly by truck to Puerto Santo Tomas. Although this alternative would have the advantage of eliminating the need to construct an expensive barge terminal, it would increase distances trucks have to haul by an estimated 60 to $70 \mathrm{~km}$. The alternative would also require the use of the port and associated handling, storage, and loading facilities. The increased volume of trucks would also add to the congestion already evident on roads leading into the port.

Simpson conducted an assessment of the handling and storage facilities at Puerto Santo Tomas during early project planning stages and concluded that they were inadequate to handle logs. The EIA team visited the port and reached a different conclusion. There is a new port administration, and the port is undergoing a major expansion. The dock is being doubled, and large areas are being created for handling and storage. Port officials stated that although they are optimized for handling of containers, they have the capability or can acquire the necessary equipment to handle and load the $2.5 \mathrm{~m}$ logs. However, a major limitation of this alternative are the "port costs." These port costs are more than twice the estimated costs of the truck shipments, and unless they can be reduced through a negotiated rate, are probably too high to make the Simpson operation economically viable at current prices for delivered hardwood chips in Texas. The port costs (or wharfage as it is called in Simpson's environmental report) were the principal reason for rejecting land transport and use of the ports when planning forestry operations in Guatemala in the 1980s.

\subsubsection{Truck and Rail To Puerto Santo Tomas}

Running more or less parallel to the Rio Motagua and the highway to Puerto Barrios is an abandoned narrowgauge railway. At one time, the railway was used to move agricultural products, primarily bananas, to Puerto Barrios. The improvement of the road connecting the banana plantations with the towns of Morales and Puerto Barrios and the modernization of the Puerto Barrios port following the mid-1970s earthquake ended the use of the railroad. A possible alternative for Simpson and other agricultural businesses would be to consider the rehabilitation of the railway.

The major obstacle to the use of the railway would be the extremely high cost required to rehabilitate the line. Certainly, some form of Government support would be required. Furthermore, the relatively low daily volume of the Simpson operation (one loaded barge is the equivalent of about 15 rail hopper cars) would mean that other uses of the railroad would have to be found in order to spread the investment costs. This alternative would have to be considered in the broader economic development context of the area, perhaps as a measure to reduce the ever increasing volume of commercial truck traffic on the highway connecting the ports to Morales and Guatemala City.

\subsubsection{Construct Road along Oil Pipeline Right-of-way}

An oil pipeline runs parallel to the road connecting Fronteras and Modesto Mendez and the Peten (Figure 1). About $1 \mathrm{~km}$ downstream of the Rio Dulce bridge the pipeline passes under the river and then runs more or less parallel to the south shore of the Rio Dulce skirting the $1 \mathrm{~km}$ national park buffer. The pipeline ends at 
Puerto Santo Tomas. The vegetation on either side of the pipeline is kept cleared for access and maintenance. It is possible for 4-wheel drive vehicles to travel on large sections of the right-of-way.

This alternative would involve constructing an all weather road along the right-of way. Like the proposed location of the barge terminal, an access point to the pipeline could be secured so that it would be central to Simpson's plantation sites. The pipeline right-of way would provide a much more direct route to the coast. The total distance is roughly estimated at $40 \mathrm{~km}$. The major limitation of this alternative would be the high construction cost. The right-of-way passes over many hilly sections that would require major road building. The high cost of the road construction and relatively low volume of traffic would make this alternative uneconomic for Simpson and perhaps environmentally unwise given the proximity of the pipeline to the park buffer zone. Additional study would be required to assess technical feasibility, costs, and environmental impact.

\subsection{TRUCK AND BARGE VIA RIO SARSTUN}

Another alternative that would require additional study for technical feasibility, cost, and potential environmental impact is the relocation of the proposed barge terminal to the Rio Sarstun. The Rio Sarstun forms the border between Belize and Guatemala and is about 30-35 km north of the Rio Dulce. Although not as wide as the Rio Dulce, the Rio Sarstun is a relatively deep, meandering river that empties into the Bahia de Amatique $20-25 \mathrm{~km}$ northeast of Livingston. This alternative would require Simpson to locate the barge terminal to a site off the.Fronteras to Modesto Mendez main road. This alternative would have the advantage of moving all plantation wood harvested on the north-side of Lago de Izabal and the Rio Dulce completely out of the Rio Dulce protected area. Movement of harvested wood from south-side Rio Dulce plantation sites would have to cross the Rio Dulce bridge, but this would occur, perhaps, only during 2 years out of the 5 year rotation. The obvious cost disadvantages of this alternative are the longer road haul distances, especially for the south-side plantation sites and the probable need to use smaller, less efficient barges to navigate the Rio Sarstun. Environmentally, the lower portion of the Rio Sarstun is a major wetland area and the point where it empties into the Bahia de Amatique is a major spawning area for shrimp. Use of the Rio Sarstun is likely to raise transboundary issues with Belise.

\subsection{PREPROCESSING OF WOOD}

The proposed Simpson action calls for the growing, harvesting, and transport of whole, debarked logs from the Rio Dulce to Galveston, Texas. There is no processing of the gmelina trees other than the removal of the bark. This altemative considers whether it would be technically and economically feasible to process the trees locally. This could include chipping as a minimal form of processing or consideration of pulping the trees and shipping pulp to Galveston, Texas. Although specific recommendations are beyond the present scope of this study, local processing that would increase the value-added would serve to lower the volume of material transported and make shipment to Texas more cost effective. Containers would also be used to make transport of the processed gmelina less costly.

\subsection{NON-CONVENTIONAL ALTERNATIVES}

A number of non-conventional alternatives are potentially feasible, such as cable and skyline systems via the pipeline right-of-way. Cable and skyline systems tend to be used in difficult terrain situations involving highgrade logs (e.g., douglas fir in the U.S. pacific northwest). The relatively low value of the pulp logs, the high 
capital cost, the need to move large quantities of product in order to lower unit costs, the cost of terminal facilities on either end, etc. make this particular non-conventional alternative technically difficult and uneconomical. This non-conventional alternative would still require the use of the bridge to reach the northside plantations.

\subsection{NO-ACTIONALTERNATIVE}

As discussed earlier, Simpson began planting gmelina in the late 1980's. Trees were planted at a density of 1100 trees per ha and many of the plantings are now ready for harvest. The no action alternative is one in which Simpson simply abandons and sells-off their Guatemalan plantation operations because CONAMA does not issue the appropriate permits to begin construction of the Ensenanda Nana Juana barge facilities.

Under a no action alternative, it is likely that the plantations would be sold and harvested with the land eventually returning to cattle ranching. The impact would be loss of employment and income for about 1200 workers and loss of income to the local economy in general. Simpson would also lose part of their gmelina plantation investment.

\subsection{COMPARISON OF CONSTRAINTS AND IMPACTS OF THE PROPOSED ACTION AND ALTERNATIVES}

A summary of the major technical and economic constraints as well as the major impact pathways expected from each of the alternatives is summarized in Table 1 . As noted at the outset of this Section, there are only four alternatives that can be implemented to coincide with Simpson's planned harvesting schedule (mid1997). Each of these alternatives (truck haul to Puerto Santo Tomas, relocation of the terminal to Simpson's property on the north shore of Lago de Izabal, relocation to a terminal on the south shore, and dual terminals on north and south shores of Lago de (zabal) is likely to involve higher costs to Simpson. There may also exist some technical constraints to going forward with these alternatives, such as road access to the south shore of Lago de Izabal. The other alternatives need additional study. However, if proven to be technically feasible, implementing them (with the possible exception of the Rio Sarstun alternative) may require substantial capital investment.

Each of the alternatives including the proposed action involve potentially significant environmental impact pathways. For the proposed action, these impact pathways include the construction of the barge terminal, the operation of the barges in the Rio Dulce, and increased congestion at the Rio Dulce bridge-an access point for tourism. The alternatives requiring relocation of the barge terminal can avoid the construction impacts in the intensive use zone. Possible congestion at the bridge is only avoided if dual terminals are constructed on Lago de Izabal. Although the other alternatives need additional study, these alternatives cannot avoid potential congestion impacts from increased truck traffic given that Simpson has operations on both sides of the Rio Dulce corridor. 
Table 1. Identification and comparison of alternatives

\begin{tabular}{|c|c|c|}
\hline Alternative & Technical/economic issues & $\begin{array}{l}\text { Potential significant } \\
\text { impact pathways }\end{array}$ \\
\hline Proposed action & $\begin{array}{l}\text { - Requires building a canal into } \\
\text { the shoreline }\end{array}$ & $\begin{array}{l}\text { - Construction of barge terminal } \\
\text { - Operation of barges } \\
\text { - Disturbance of sediments } \\
\text { - Congestion at bridge }\end{array}$ \\
\hline $\begin{array}{l}\text { Relocate barge terminal to north } \\
\text { shore Lago de Izabal }\end{array}$ & $\begin{array}{l}\text { - Road access and cost } \\
\text { - Possible dredging }\end{array}$ & $\begin{array}{l}\text { - Operation of barges } \\
\text { - Possibility for dredging } \\
\text { - Congestion at bridge }\end{array}$ \\
\hline $\begin{array}{l}\text { Relocate barge terminal to south } \\
\text { shore Lago de Izabal }\end{array}$ & $\begin{array}{l}\text { - Road access } \\
\text { - Acquiring a site } \\
\text { - Dredging of channel }\end{array}$ & $\begin{array}{l}\text { - Operation of barges } \\
\text { - Dredging } \\
\text { - Congestion at bridge }\end{array}$ \\
\hline $\begin{array}{l}\text { Dual terminal facilities on Lago } \\
\text { de Izabal }\end{array}$ & $\begin{array}{l}\text { - Acquiring a site on south shore } \\
\text { - Dredging of channel } \\
\text { - Road access and costs }\end{array}$ & $\begin{array}{l}\text { - Operation of barges } \\
\text { - Possibility for dredging }\end{array}$ \\
\hline Truck to Puerto Santo Tomas & - Higher costs & - Congestion at bridge \\
\hline $\begin{array}{l}\text { Truck and rail to Puerto Santo } \\
\text { Tomas }\end{array}$ & $\begin{array}{l}\text { High capital investment cost } \\
\text { Time required for } \\
\text { implementation } \\
\text { - High operating costs without } \\
\text { other uses }\end{array}$ & - Congestion at bridge \\
\hline $\begin{array}{l}\text { Construct road along oil pipeline } \\
\text { right-of-way }\end{array}$ & $\begin{array}{l}\text { - High capital investment cost } \\
\text { - Time required for } \\
\text { implementation } \\
\text { - High operating costs without } \\
\text { other uses }\end{array}$ & $\begin{array}{l}\text { - Congestion at bridge } \\
\text { - Construction of road near park } \\
\text { boundary }\end{array}$ \\
\hline Truck and barge via Rio Sarstun & - Additional study required & - Additional study required \\
\hline Non-conventional alternatives & $\begin{array}{l}\text { - High capital investment cost } \\
\text { - Time required for } \\
\text { implementation } \\
\text { - High operating costs without } \\
\text { other uses }\end{array}$ & $\begin{array}{l}\text { - Congestion at bridge } \\
\text { - Construction of road near park } \\
\text { boundary }\end{array}$ \\
\hline Pre-processing of wood & - Additional study required & - Additional study required \\
\hline No-action & - None & $\begin{array}{l}\text { - Loss of employment and } \\
\text { income } \\
\text { - Land reverts to other uses } \\
\text { (cattle ranching) }\end{array}$ \\
\hline
\end{tabular}




\section{AFFECTED ENVIRONMENT}

\subsection{SOCIOECONOMIC RESOURCES}

\subsubsection{Population and Demographics}

The population density of the Izabal region is 35 people per square kilometer or slightly less than half of the national population density $\left(85 / \mathrm{km}^{2}\right)$. The Izabal region has over $8 \%$ of the country's land area and contains $3.4 \%$ of the nation's total population. In the last twenty years, the population of Izabal and the development of settlements in the Rio Dulce corridor has grown considerably. The latest statistics available show that population in both rural and urban areas has increased by about $20 \%$ during the past 5 years (Table 2).

For the municipality of Livingston, which encompasses most of the Rio Dulce area, population has increased by more $25 \%$ in the last 5 years. Much of this growth in the Rio Dulce corridor can be attributed to the construction of the highway connecting the Peten to Izabal and the building of the Rio Dulce bridge. Before this construction most of the population of the Rio Dulce was concentrated in the areas surrounding the principal towns-Livingston, Puerto Barrios, and Morales. Today, there are significant population centers in Fronteras, San Felipe, El Relleno, La Bacadilla, Cayo Quemado, and minor settlements in another eight villages.

A large part of the increase in the rural areas of Livingston is attributable to the in-migration of Kek-chi (Mayan) Indians from the Central Highlands. In the mountains bordering the Rio Dulce, there are now more than 50 small Kek-chi villages with a combined population in excess of 6000 . Development of summer or vacation homes, tourist hotels, marinas, and other settlements have also grown considerably in recent years. All of the development in the Rio Dulce corridor has to a large extent been disorganized and unplanned.

Table 2. Estimated urban and rural population in Izabal (1990 and 1995)

\begin{tabular}{|c|c|c|c|c|c|c|}
\hline \multirow[b]{2}{*}{ Municipality } & \multicolumn{2}{|c|}{ Total } & \multicolumn{2}{|c|}{ Urban } & \multicolumn{2}{|c|}{ Rural } \\
\hline & 1990 & 1995 & 1990 & 1995 & 1990 & 1995 \\
\hline Puerto Barrios & 60,084 & 66,051 & 38,177 & 39,379 & 21,907 & 26,672 \\
\hline Livingston & 44,600 & 55,528 & 5,146 & 5,376 & 39,454 & 50,152 \\
\hline El Estor & 44,502 & 60,358 & 19,111 & 31,201 & 25,390 & 29,157 \\
\hline Morales & 89,587 & 101,155 & 3,339 & 3,387 & 86,249 & 97,768 \\
\hline Los Amates & 77,444 & 87,445 & 2,381 & 2,468 & 75,063 & 84,976 \\
\hline Total & 316,217 & 370,538 & 68,155 & 81,812 & 240,062 & 288,726 \\
\hline
\end{tabular}

\subsubsection{Recreation and Tourism}

Tourism in Guatemala is the second largest source of foreign earnings next to coffee. Instituto Guatemaiteco de Turismo (INGUAT) projects that tourism will surpass coffee as the largest source of foreign earnings by the year 2000 . In 1994, tourism revenue exceeded $\$ 258$ million - an increase of $22 \%$ since 1991 (INGUAT 
1996). The number of tourists in 1994 totaled more than 537,000 with over 80,000 visiting Izabal and the Rio Dulce. INGUAT expects tourism to surpass 815,000 in the year 2000 and generate $\$ 550$ million. This estimate is based on an average visit of 8 days with daily expenditures of $\$ 85$. Data are not available on the amount of tourist spending in Izabal.

Although agriculture is the predominant commercial activity in Izabal, tourism and, possibly, ecotourism are growing aspects of the economy. Figure 3 summarizes the expected growth in tourism for the Department of Izabal including the Rio Dulce corridor. These projections are from INGUAT and are based on an assumption that $15 \%$ of tourists visiting Guatemala visit the Rio Dulce corridor (INGUAT 1996). There are two projections shown in Figure 3. One is based on a simple extrapolation assuming a continuation in the development of the tourist infrastructure. Under this "status quo" scenario tourist visitation increases by about 42,000 and reaches 128,000 over the next ten years. Under an organized tourist infrastructure development plan proposed by INGUAT, tourism visitation is projected to more than double in the next ten years. Under the tourism development project, the central and municipal government would provide funding to improve transport infrastructure, make investments in the protected areas, fund tourism marketing efforts, improve urban infrastructure, and assist the private sector in developing hotels and other tourism activities. About $60 \%$ of the tourists visiting the Rio Dulce are foreigners with the majority of them coming from North America.

Tourists in the Rio Dulce area can take advantage of many opportunities. Among the more notable are: the towns of El Estor and Mariscos on Lago de Izabal, the rivers flowing into western Lago de Izabal (e.g., the Rio Polochic), Castillo de San Felipe and the towns of Fronteras and El Relleno at the Rio Dulce bridge, El Golfete, the Rio Chocon Machaca, Chocan Machacas Biotope, Cayo Grande, the hot springs, Ak Tenamit, the Canyon, Siete Altares, the Cerro San Gil Ecological Reserve, the Carribean town of Livingston, Punta de Manabique, and Puerto Barrios. In addition, there is the Mundo Maya project. This project, which was begun in 1989, is a joint venture of the five Meso-American countries that share a common cultural, historical, and environmental heritage. A goal of the project is to create a single tourist visa for the region. Not only for its unique attractions, the Rio Dulce area is viewed as a stopping-off destination for tourists on their way to the Peten, the coast, and Honduras.

\subsubsection{Non-Tourist Economic Activities}

From the beginning of operations in 1988 to the present time, Simpson has invested approximately $\$ 20$ million in the gmelina plantations. About $\$ 6$ million of this amount has been invested in equipment, construction, land purchases, and land rental. Most of the remainder has gone for worker salaries. On an annualized basis, investment in the local economy has averaged about $\$ 2.5$ million per year. In 1997 , Simpson will invest $\$ 5.4$ million and in 1998 and beyond about $\$ 6$ million will be invested annually-onethird in replanting and two-thirds in harvesting. Simpson currently employs 600 workers, most of which are hired through subcontractors. Another 600 workers will be hired once harvesting operations start.

Gmelina plantations currently occupy 7500 ha and plans include expansion up to 10,000 ha next year (see Section 3.2). Additional expansion of the Simpson project depends on how efficiently current operations are managed and whether anticipated productivity levels can be attained. Much also depends on trends in prices for clean hardwood chips. Higher U.S. prices for hardwood chips translates directly into more favorable conditions for the export of Guatemalan gmelina.

In addition to the Simpson operation, the Rio Dulce area supports subsistence and commercial agriculture, cattle ranching, rubber and teak plantations, fishing, oil pipeline activities, and numerous other activities that 


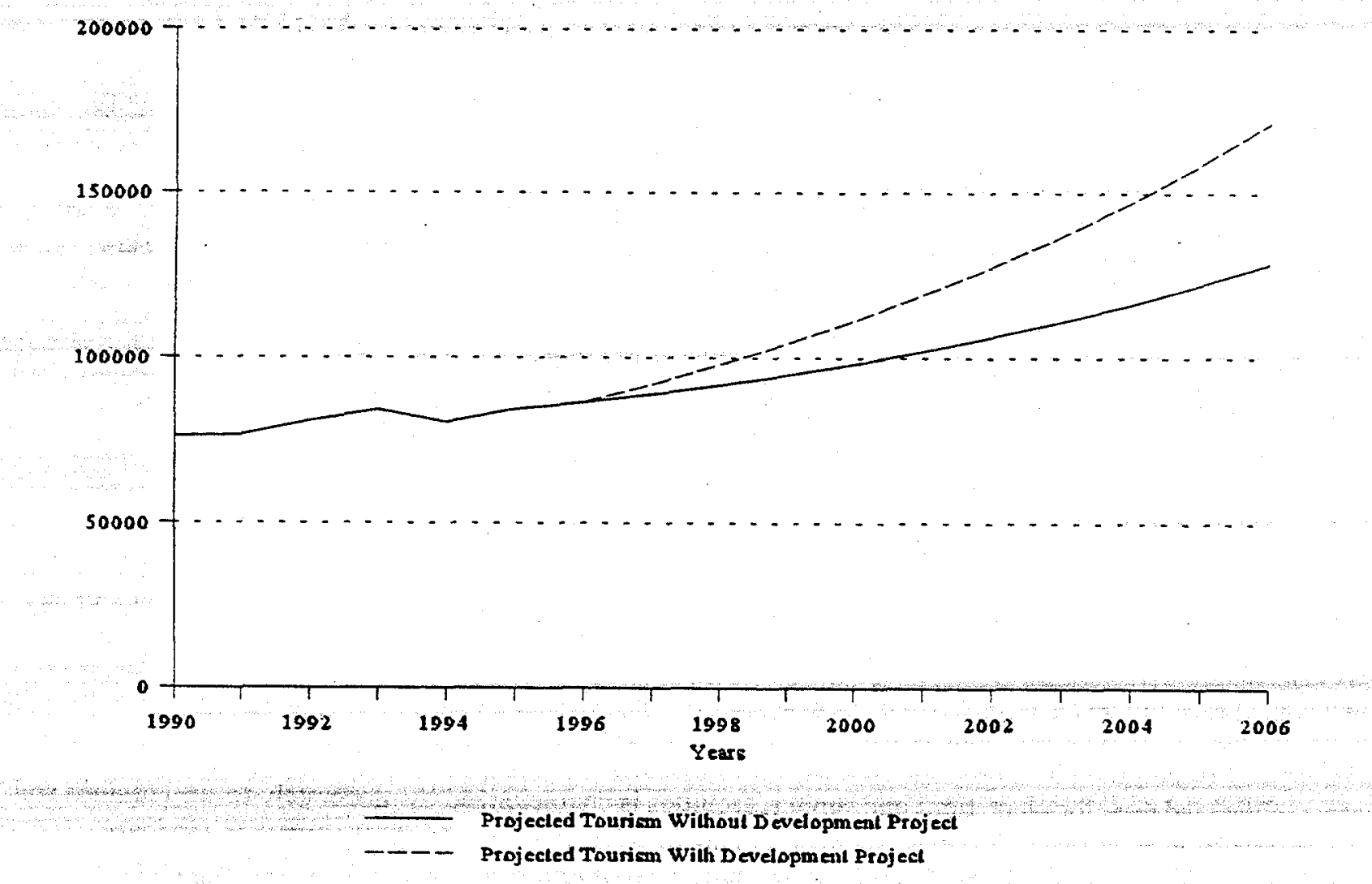

Figure 3. Projected tourism in Izabal (Source: INCUAT 1996).

are associated with tourism - boat repair, docks, restaurants, etc. At one time the Rio Dulce was used by Exmibal, a nickel mining operation at El Estor on Lago de Izabal. The Rio Dulce area has also been explored for hydrocarbons and other minerals. Economically, the Rio Dulce and Lago de Izabal have considerable potential for the exploitation of natural resources and as a low-cost transportation highway to the rich valley of Panzos via the Rio Polochic.

\subsubsection{River and Terrestrial Transport and Safety}

With the exception of infrequent use of the Rio Dulce by cattle ranchers, there is essentially no commercial agriculture or industry (non-tourism) traffic on the Rio Dulce. However, the river is used extensively by local fisherman, who are frequently seen in small dugout canoes (cayucos). The local fisherman tend to fish in narrow sections of the Rio Dulce-near the bridge and in the canyon.

The major use of the Rio Dulce and Lago de Izabal is for passenger travel, boating, and tourism. There is a regular passenger ferry on Lago de Izabal between Mariscos and El Estor and a passenger ferry in the Bahia de Amatique between Livingston and Puerto Barrios. There are no scheduled passenger ferries or boats on the Rio Dulce itself. However, numerous small boats can be rented or hired to transport small cargo and people on the Lago de Izabal or the Rio Dulce.

The Rio Dulce is used by many pleasure vessels. These boats range in size from small pleasure craft to large ocean-going yachts. The growth in tourism and recreation in the area is likely to result in an increase in small 
boat traffic. Also, there exists potential for shallow-draft cruise type ships to enter the Rio Dulce. Concerns have been raised that the presence of tugs and barges will lead to a number of accidents involving the cayucos and small-to-large pleasure craft. The Canyon area of the Rio Dulce narrows to $175 \mathrm{~m}$ and makes sharp, view-restricted turns.

A major limitation in the Rio Dulce area is the inadequate system of roads. Although there are major roads connecting the Rio Dulce with the Peten, Guatemala City, and the coast, secondary roads in the area are generally in poor condition. Moreover, the bridge across the Rio Dulce, which was built in the early 1980s, has only two lanes. The Rio Dulce bridge and the towns on either side of the bridge are viewed as major access points for the ecotourism. These areas are already congested due to the presence of trucks and uncontrolled development. The presence of additional trucks from the Simpson operation could compound this congestion and increase the likelihood of accidents.

\subsection{LAND AND SOILS}

Gmelina plantations currently occupy about 7500 ha, and Simpson plans to expand them to 10,000 ha by the end of 1997 (Forestal Simpson 1996). They could be extended by an additional 6000 ha or more. Additional land ( $<20 \mathrm{ha}$ ) is occupied by nursery and propagation operations for gmelina (and other species), experimental plantations, and storage/staging areas for equipment, chemicals, and other supplies.

Most of the land used for plantations and support facilities is characterized by moderately-to-well drained soil with high clay content that is favorable to gmelina growth. The previous use of the plantation land was generally range and pasture for cattle grazing with patches of interspersed vegetation. This vegetation includes individual coroza palms, the stately San Juan trees, clumps of trees or shrubs, strands of riparian vegetation, and occasional highly impacted forest remnants. To a large extent, this description also applies to the character of the land surrounding the gmelina plantations. The quality of range and pasture management varies so much that it cannot be considered as one land use category for environmental purposes. In a few cases, small parcels of land in rowcrops and impacted forests have been replaced with plantations.

Simpson began purchasing land for the establishment of gmelina south of the Rio Dulce in the latter half of the 1980s. Planting began in 1988 on the south side and continued through 1995 except for 1994 (Figure 1). In the early 1990s, Simpson bought land on the north shore of Lago de Izabal and entered into numerous land lease arrangements on the north side of the river. North-side plantings began in 1993 and continue through 1996.

Simpson plans to begin harvesting operations on the south side of the Rio Dulce during the latter half of 1997, after completion of the proposed barge terminal. Harvesting will likely continue on the south side through 1998 and into 1999. Harvesting on the north side of the river and Lago de Izabal will likely begin sometime during 1999. After the initial harvesting of all sites, superior clones of gmelina will be reestablished. The Simpson plantation will then be managed on a sustainable 5-year rotation or cutting cycle involving 1800 ha annually.

The plantations themselves are closely-spaced monocultures of gmelina, an exotic to Guatemala. Intervening native or invading vegetation is rare. Occasional trees remain but nearly all of the former vegetation is eliminated. Where land is too wet for gmelina, other vegetation either reinvades or is permitted to remain. There appear to be few riparian corridors, fencerows, or plots of native vegetation in the existing plantations. 
The reforestation of land with monocultures has both positive and negative aspects. The gmelina plantations offer added forest cover and improved water quality, but also increase landscape monotony. The plantations could act more efficiently as wildlife corridors if managed with modifications to provide some level of diversity. Such modifications would assist the ecotourism and biodiversity objectives for the region.

Initial land treatment in the plantations involves intensive clearing (most previously used as pasture), burning, and some form of tillage or bedding followed by tree planting and intensive weed control by hand and with use of herbicides sprayed from back packs. Crown closure in 6 to 9 months allows early curtailment of weed control. Fertilizer application involves 1 or more applications of nitrogen, phosphorus, and potassium (4-18-20 composition) at $300 \mathrm{~kg} / \mathrm{ha}$. Pest control consists primarily of chemical treatment of leafcutter ant colonies.

After the initial harvest, replanting will probably not involve as intense site preparation as the initial establishment. Replanting will involve more species, some probably native, as Simpson becomes comfortable with the success of gmelina. Drawing from experiences with other plantations in Brazil, India, and the U.S., one might expect Simpson to settle on about 3 species of trees. The first will probably continue to be gmelina and will comprise about 70 to $80 \%$ of all planting although several different clones should be anticipated. The other species are likely to include one or two native species. Other species will continue to be tested on research plots. Working operationally with more species becomes a progressive economic burden in the propagation procedures with each additional species.

Plantation equipment storage and maintenance areas contain waste crankcase oil, other waste lubricants and fluids, old tires, and worn out equipment disposal areas. Storage areas containing herbicides, pesticides, fertilizers, and nursery materials are subject to occasional spills from broken or ripped containers, pallet disposal, and waste containers/bags. The cleaning of equipment carrying chemicals (e.g., back pack sprayers, fertilizer equipment) will generate contaminated waste water either at the equipment sheds, in the field, or near the nursery. Emissions from nursery operations involve surplus irrigation water and rinse water from equipment cleaning. However, chemical use in nursery operations is kept to an absolute minimum, by nursery standards. Control measures for introduced plant diseases in the nursery are minimal based on experiences at other gmelina operations in Costa Rica.

\subsection{SURFACE WATER}

Currently, there is only a limited amount of barge traffic on the Rio Dulce. These barges are considerably smaller in size and are used for moving cattle. Their use on the river tends to be unscheduled and infrequent. Commercial barge traffic (i.e., $10 \mathrm{~m} \times 60 \mathrm{~m}$ barges) and terminals do not presently exist on the river. Existing water recreation uses, pleasure craft, and light commercial boat traffic on the river can be hectic at times. There are four aquatic environments of significantly different character within the Rio Dulce transport corridor. These environments are as follows:

- The Rio Dulce narrows near the Rio Dulce Bridge and the Canyon narrows near the mouth of the Rio Dulce experience heavy river traffic at times. They are used principally by the local population for fishing and transportation in cayucos or other small craft.

- El Golfete, a large natural lake, is of varying brackish and fresh water composition depending on season. The northern shoreline adjoins the Chocon Machacas Biotope Reservation set up for Manatee protection and conservation of tropical rainforest biodiversity.

- The navigable Rio Chocon Machaca passes through the Chocon Machacas Biotope and 
provides direct access to the northern gmelina plantations. It has been used to some extent for material transport to the plantations. It is also used by the local population for transportation and transport of goods via small craft. Wilderness conditions exist along the river inside the Reservation.

- Bahia de Amatique which contains Puerto Barrios and Puerto Santo Tomas is heavily used for commerce, transportation, and recreational boating. The mouth of the Rio Dulce is very shallow, measuring less than $2 \mathrm{~m}$ at low tide.

\subsection{AESTHETICS}

\subsubsection{Definition}

Aesthetics comprises an important consideration in the proposed Simpson action because of the potential conflict between commerce and the aesthetic quality of an ecotourism experience as implied in the Rio Dulce Master Plan. Aesthetics are a combination of the physical conditions experienced and sensitivity to those experiences. Several past efforts in aesthetic evaluations for EIAs (GSA Air Quality Improvement Project, Washington, D.C. 1996; Herzog 1984; Hammitt 1988) have focused entirely on visual resources. These evaluations have been within cities and along scenic highways. A few have considered sound or smell where these senses were overwhelming issues (e.g., sound near airports or smell near dumps and factories). The plan for the Rio Dulce National Park is to encourage ecotourism which would combine sound, smells, and even the sense of touch with the visual experience to culminate in the aesthetic experience.

The Rio Dulce Intensive Use Zone, in some places contains or can regain the natural resources needed to provide an ecotourism experience along the river and its shoreline. Such an experience may include the humid, clean smell of the river and forest, the howling of golden mantled howler monkeys, views of the rainforest, and the activity of local fisherman in very small boats (cayucos). Capturing or retaining this experience can be very important to attracting less intensive types of ecotourism. Such an approach would require a reversal of present trends in the Intensive Use Zone. More intensive forms of tourism are already at work involving pleasure craft with noisy motors, substantial weekend boat traffic, and shoreline developments of marinas, restaurants, housing, and various service type businesses. The intensity and noise levels are increasing and pushing aesthetic experiences away from ecotourism and toward intensive tourism and predominance of commerical structures and activities. The proposed Simpson actions would add limited heavy commercial activity to this zone of the Rio Dulce National Park. The large barges (60 m long) and the tugboat $(600 \mathrm{hp}$ ), the clearing of large trees along the river's edge, the daily (weekday) activity of loading wood from approximately 100 trucks onto a barge, and the traffic that would be generated comprise some of the immediate aesthetic impacts that the barge activity would introduce to the area.

The proposed barge development in the Intensive Use Zone would: (a) provide the first active step in industrialization in the zone, (b) contribute to intensified human use and congestion on the roads and river along with the ever increasing recreational uses, and (c) further incrementally commit the aesthetics of the zone to industry and an intensive, developed recreation experience. The plan for the Rio Dulce National Park is vague about desired development directions in the Intensive Use Zone regarding industry, intensive, developed recreation, or ecotourism with resource conservation. The current question concerns whether to permit continued incremental declines in the natural environment and aesthetics as being compatible with present development trends, or to implement plans that strive for an improved natural aesthetic experience that relates directly to ecotourism. The proposed Simpson action is but one step in the process of environmental and aesthetic change. 
In this EIA, the resources of aesthetic consideration are the visual, auditory, and olfactory senses. The sense of touch which would include feeling humidity, the breeze, the temperature, and precipitation are not expected to be measurably affected by the proposed Simpson activity. It is not inconceivable that the reforestation by Simpson could slightly improve these types of experiences, but quantification of such variables is beyond the scope of this evaluation.

\subsubsection{Barging}

Wood barging terminals and commercial barge traffic are not frequently observed within national parks around the world unless: (a) heavy commercial traffic was present before park establishment; (b) the water body is large enough to diminish the impact of the size of the barges; and/or (c) intensive motorized water recreation is a dominant theme (as opposed to less developed forms of ecotourism). Frequency of commercial barge traffic is a consideration. Compatibility of these activities in the Rio Dulce National Park has been repeatedly raised as a significant concern by some local stakeholders. This is complicated by localized deterioration of aesthetic conditions by unregulated development.

Barge traffic to some can be either interesting or an insignificant factor with respect to aesthetics. This is the case for the Tennessee River in the southeast U.S. where river recreation can be heavy. Barge traffic is relatively light and generally not considered to affect recreation or aesthetics negatively. However, there are some perceived aesthetic conflicts with ecotourism where rainforest conditions are the focus. The Rio Dulce region, for practical considerations, contains both development and perceived pristine conditions. The river functions as a staging area for ecotourism elsewhere and contains in itself both developed recreational value and direct access to wilderness ecotourism.

\subsubsection{Key Aesthetic Areas}

The Rio Dulce National Park is characterized by six distinct aesthetic areas. Each of the six is briefly described below.

\subsubsection{Park Intensive Use Zone and Rio Dulce Bridge Area}

The area around the Rio Dulce Bridge including the proposed loading terminal, Fronteras, Castillo de San Felipe, and the Intensive Use Zone are extremely active human use areas. Shoreline uses are evolving into increasingly concentrated conditions which are reducing or eliminating experiences with the natural environment. Increasing concentration of human activity is also increasing pollution of aquatic systems.

\subsubsection{El Colfette}

This is a landscape of large scale and sweeping views of natural conditions and native culture. River traffic including infrequent barge traffic is an insignificant component and does not offer a conflict with existing or desired conditions using almost any criteria. Aesthetically, the area is a significant resource that would not be affected by the Simpson proposed barging activity.

\subsubsection{Chocon Machacas Reservation and Rivers}

The Chocon Machacas is the most wild and highly protected of all areas in the Rio Dulce corridor. Within the Rio Dulce National Park Master Plan, it is classified as a Primitive Zone. Here, the resources are quietness, sounds of nature, and protected biodiversity. These resources can be easily affected by commerce and trade. The relatively few remaining manatees are a major biological resource vuinerable to impacts from human 
intrusion. Some tourism, local fishing/crabbing, and local movement of indigenous people, their goods, and infrequent movement of cattle by small barges now occurs. The Rio Chocon Machaca is navigable as are some of the bays and other tributaries. These waters will be very attractive for barge use and access to gmelina plantations although use of these water access ways is not officially proposed as an action.

\subsubsection{Rio Dulce Canyon}

Most of this area is designated as a Special Protection Zone which is intended to maintain a substantial degree of native vegetation, forestry, and agroforestry, but includes allowances for private property activities compatible with ecotourism. The area now consists of small indigenous housing, minimal farming, and extensive fishing from small boats along the river. Much of the zone consists of a deep, turbulent, gently winding river course 175-200 meters wide (Forestal Simpson 1996) with nearly vertical shorelines. Two very abrupt river bends and very steep, high canyon walls, and partially covered with clumps of rainforest species, create an unusual experience for tourists. The aesthetic resources likely to be affected by the proposed action appear to be river-oriented. That is, the barge and tug traffic plus navigation structures would affect sights, sounds, and the extent of congestion on the river within the canyon.

\subsubsection{Plantations and Roads}

Views of the middleground and background from the Intensive Use zone now include plantations. Plantations have both positive and negative aesthetic effects along roads. They generate a more wooded, shade-dominated experience when displacing rangeland, pasture, and cropland (Bell 1994). At the same time they have the negative effects of creating monotonous tunnels through monocultures, and prohibiting views of the landscape that are offered by more open areas. A combination of the tunnels and open views is most desirable, especially when views contain water scenes with a series of mountain ranges in the distance and natural/pastoral or wild land uses comprising most of the view. Views can also include nicely nestled towns and developments.

Aesthetic considerations within the plantations are principally those concerned with workers, visitors to Simpson operations, and social workers looking after the conditions of the Simpson labor force. The most serious aesthetic concerns involve the visual and olfactory aspects of sanitation and human waste (e.g., latrines and drinking water).

\subsubsection{Amatique Bay and Surrounding Land}

The proposed Simpson actions will impose barge mooring, barge movement, wood movement between barges, barge loading onto sea-worthy barges, tug boat activity, and perhaps some navigational aid structure onto existing uses of Amatique Bay. None of these proposed activities should be aesthetically inconsistent with ongoing and planned uses in the bay area. Ocean going ships, fish trawlers, local work boats, ferries, and pleasure craft already utilize the bay. Nearby tourism development has not suffered from these nor have they raised aesthetic issues.

\subsection{WATER QUALITY AND HYDROLOGY}

The watershed that feeds Lago de Izabal includes the Rio Polochic which drains into the western end of the lake, and numerous smaller tributaries that flow from the southern side of the mountains of Sierra de Santa Cruz and the northern side of the mountains of Sierra de las Minas. The Rio Dulce flows out of Lago de Izabal through a narrow passage at Castillo de San Filipe on the northeastern end of the lake, and continues 
approximately $37 \mathrm{~km}$ eastward through El Golfete, another large lake, to Bahia de Amatique (Forestal Simpson 1996). Part of the northern shoreline of El Golfete adjoins the Chocon Machacas Biotope that was established for Manatee protection and conservation of tropical rainforest biodiversity.

The Rio Dulce varies considerably in width and depth. The width as it exits Lago de Izabal is about $200 \mathrm{~m}$; at the upper end of EI Golfete it widens to approximately $3.8 \mathrm{~km}$; it then narrows to $175 \mathrm{~m}$ in the section called the Canyon below El Golfete; and again widens to about $200 \mathrm{~m}$ at the entrance to Bahia de Amatique. The depth of the Rio Dulce varies as much as the width ranging from about $15 \mathrm{~m}$ in the Canyon to as little as 1.7 $m$ at Bahia de Amatique. The average depth of the Rio Dulce is considered to be $3 \mathrm{~m}$ (MAREX 1996).

Maintaining water quality within the Rio Dulce National Park is a major concern of the park Master Plan. The Plan's objectives state that human wastes will be treated and resources will be managed to maintain the productivity of the aquatic ecosystem. However, water quality is currently being degraded.

No municipal sewage treatment facilities exist in any of the communities along the river. In-ground septic systems have been installed for some of the newer homes and public establishments; however, uncontrolled disposal is still a widespread practice. Large amounts of wastes are dumped or washed directly into the river. Continued growth with added population and congestion, especially in local communities will add to the waste load. Other potential sources of contamination include agricultural and construction runoff (nitrates from fertilizer and sediments from erosion); trash resulting from improper disposal of solid wastes; and fuels, oils, and fluids from leaks, spills, and improper disposal of such wastes.

Background water quality data for the Rio Dulce are very sparse. In January 1996, a Simpson contractor conducted one-time sampling for some pertinent contaminants at five locations along the river: (1) Ensenada Nana Juana, from the bank at the proposed barge terminal site; (2) $50 \mathrm{~m}$ from the bank; (3) at a small dock in the lagoon near the Rio Dulce bridge; (4) the mouth of Rio Chocon Machaca where it enters El Golfete; and (5) in Rio Choconcito. These data were then compared to similar data developed by Shell for several sampling sites in Lago de Izabal in 1991-93 (Forestal Simpson 1996).

The increased levels of biological oxygen demand (BOD) and sulfates found in the 1996 samples are indicative of contamination from human domestic wastes and/or agricultural runoff into the river. The BOD levels ranged from 14 to $26 \mathrm{mg} / \mathrm{L}$ while the BOD standard for recreational areas is $3 \mathrm{mg} / \mathrm{L}$. High electrical conductivity signifies the existence of dissolved salts possibly from fertilizer runoff and/or minerals associated with saltwater intrusion which is most pronounced during the dry season. During the dry season the lake and river levels drop by $0.5 \mathrm{~m}$ or more, and flow through the lake and river are reduced. In some years, salt water intrudes upstream to the Rio Dulce bridge.

\subsection{BIODIVERSITY}

Biodiversity is of special concern in the Rio Dulce National Park. The biological resources are unique and are visibly enduring stress and degradation in many areas. There is little systematic scientific information to document the past biodiversity of the area, the stress it is enduring, and the degradation it has undergone.

The area is comprised of a heavily impacted tropical rainforest and water systems that are fresh, to brackish, to nearly sea water. As a result fish populations include a mix of fresh and salt water species, depending on the season and the degree of salt water intrusion upstream. There is anecdotal evidence of shark and porpoise sightings in the vicinity of the Rio Dulce bridge. 
Manatees, tropical rainforest plants, tropical rainforest fauna (possibly jaguar, and monkeys), aquatic birds, migratory birds, fish, and other aquatic life (turtles, crocodiles, crustaceae, etc.) are part of the biodiversity environment. Lists of the terrestrial and aquatic flora and fauna of the region are presented in several reports (Shell EIA 1991, Basterrechea 1991, and Corets 1995). More specific information was requested from NGOs concerning the Rio Dulce, but has not been received.

Sea life that depends on parts of Bahia de Amatique (e.g., juvenile shrimp) and nutrients moving down the Rio Dulce also enter into consideration. A soon-to-be-published Nature Conservancy study of migratory birds through Central America (John Beavers) identifies the Rio Dulce area as very important habitat. Small populations of manatees (90-100 in the Golfete along the Chocon Machacas Manatee Reservation and at the Polochic Reserve) may be near or past minimum viable population levels, and small remnant habitats for the golden mantled howler monkey remain in the park. These are species about which conservationists are now concerned. Some species of fish have nearly been eliminated due to constant over-fishing, monkeys have been vastly reduced in numbers, and jaguars have been all but eliminated.

From a broader perspective, the region contains several wild areas known to harbor unusual tropical rainforest species. For the most part, these wild areas and reservations are becoming more and more isolated from one another as land clearing for many different reasons forms movement barriers to the indigenous wildlife and plants. The plantations of gmelina planted and maintained by Simpson are one example of the kinds of developments that are increasingly separating wild areas. The plantations can serve both as selective conduits and selective barriers to the movement of certain species. In this way they can have an effect on the survival, movement, and recolonization of selected species and to a limited extent participate in enhancing the biological diversity of the region in the long term.

As a result of the biodiversity status and concerns, the resources that comprise the subject of this assessment, with respect to the proposed Simpson action are; the manatee, golden mantled howler monkey, gmelina plantations, pest species, and regional biodiversity and wildlife corridors. 


\section{ENVIRONMENTAL IMPACTS}

The Rio Dulce National Park is increasingly being viewed as a major natural and environmental resource that can be managed sustainably - in a way that does not affect the biodiversity of the area, does not detract from the natural aesthetic beauty of the area, and does not lower the quality of the water resources. Sustainable management of the Rio Dulce does not necessarily rule-out economic activities. However, these-activities must be consistent with guidelines establishing the Rio Dulce as a national park. For example, ecotourism and limited agro-industrial activities can be consistent with the guidelines of the park and be sustainable provided these activities do not lessen biodiversity, aesthetics, water quality, or impact the long established rights and culture of the native populations. Implicit in the decision establishing the Rio Dulce as a park and protected area was a conclusion that the net benefits of protection outweighed the net benefits from exploitation of the natural resources and environment. The following subsections address how the proposed action and alternatives have the potential to impact the socioeconomic, biodiversity, aesthetics, land use, and water quality resources.

\subsection{SOCIOECONOMIC RESOURCES}

This section discusses the direct and indirect impacts of the proposed action and the three alternatives identified as potentially viable - relocation of the barge terminal to north shore of Lago de Izabal, relocation of the barge terminal to the south shore, dual barge facilities on north and south shores of Lago de Izabal, and truck transport to Puerto Santo Tomas. Concerns have been raised by local groups that the placement of a barge terminal within the confines of the national park is not only incompatible to the sustainable development of the Rio Dulce but would also threaten tourism and potential ecotourism development. The proposed action and altematives have potential to affect socioeconomic resources directly and indirectly through employment of people, generation of income and revenues to the government, and safety of tourists and local fisherman. However, given the limited scope of this EIA and the limited availability of pertinent data, it is impossible to determine exactly what impacts Simpson's proposed action or alternatives might have on the sustainable development of the Rio Dulce. In lieu of an explicit analysis of potential impacts, the following subsections attempt to summarize at least the major issues and tradeoffs involved. Before these socioeconomic aspects are discussed a cost analysis is presented to compare the proposed action and alternatives from the financial perspective of Simpson.

\subsubsection{Cost Comparison of Proposed Action and Alternatives}

Forestal Simpson (1996) provides a summary comparative cost analysis of the proposed action and the alternative of truck hauling the logs to Puerto Santo Tomas (Table 3). Simpson stated in their environmental report that to maintain a viable operation the gmelina logs must be grown, harvested, transported to Texas, and chipped at a total cost of $\$ 37.50 /$ ton. In Table 3 , Simpson shows three delivered prices- $\$ 35, \$ 40$, and $\$ 45 /$ ton - and costs for growing and harvesting, road and water transport, and unloading and chipping in Texas. The difference between the delivered chip price and costs is the operating income from the gmelina operation exclusive of interest expenses, taxes, and return on investment. All cost components are the same for each alternative except for road and water transport costs, which includes loading, unloading, and port costs. Under the truck hauling alternative, land and river transportation is nearly $\$ 12$ ton higher than the proposed action. The difference is primarily due to the port costs associated with the land transport alternative. Port costs do not have to be paid under the proposed action. 
Table 3. Simpson's comparative cost analysis of the proposed action and road transport to Puerto Santo Tomas

\begin{tabular}{lccccccc}
\hline & \multicolumn{3}{c}{ River transport $^{*}$} & \multicolumn{3}{c}{ Land transport $^{b}$} \\
\cline { 2 - 7 } $\begin{array}{l}\text { Delivered chip price at the } \\
\text { pulp mill-\$/ton }\end{array}$ & Low & Medium & High & Low & Medium & High \\
\hline Cost items-\$/ton & $\mathbf{3 5 . 0 0}$ & $\mathbf{4 0 . 0 0}$ & $\mathbf{4 5 . 0 0}$ & $\mathbf{3 5 . 0 0}$ & $\mathbf{4 0 . 0 0}$ & $\mathbf{4 5 . 0 0}$ \\
\hline Growing and harvesting ${ }^{d}$ & 12.00 & 12.00 & 12.00 & 12.00 & 12.00 & 12.00 \\
Road and water transport & 20.60 & 20.60 & 20.60 & 32.40 & 32.40 & 32.40 \\
Unload and chip in Texas & 5.00 & 5.00 & $\underline{5.00}$ & $\underline{5.00}$ & 5.00 & 5.00 \\
Total operating costs & 37.60 & 37.60 & 37.60 & 49.40 & 49.40 & 49.40 \\
Operating income (loss) & $\$(2.60)$ & $\$ 2.40$ & $\$ 7.40$ & $\$(14.40)$ & $\$(9.40)$ & $\$(4.40)$ \\
\hline
\end{tabular}

Tiver transport means using the Rio Dulce to barge logs to the Bahia de Amatique.

Land transport means truck hauling from the plantations to Puerto Santo Tomas de Castillo.

Low, medium and high covers the range of delivered chip prices prevailing in 1994-96.

Includes all direct costs fot administration, nursery production and plantation establishment, growing and harvesting until debarked logs are stacked at roadsides in the plantations.

Tncludes all road and water transport as well as associated loading, reloading and port costs.

SOperating income (loss) is before any interest expense, income taxes and return on capital invest.

The proposed action is marginally viable if a $\$ 37.50$ break-even price is assumed. The price of delivered hardwood chips would have to rise to $\$ 50 /$ ton for the truck haul to Puerto Santo Tomas alternative to breakeven. Of course, these estimates are based on proposed action as described and do not account for expected increases in productivity and possible plantation expansion. The combination of higher gmelina productivity, greater efficiency in operations and lower costs, and expansion of the Rio Dulce plantation area to 15,000 to $20,000 \mathrm{ha}$, and the associated increase in the volume of wood to be transported could all serve to improve the financial viability of the proposed action as well as the truck haul to Puerto Santo Tomas alternative. Increased prices for clean hardwood chips in Texas could also make gmelina operations much more attractive. Alternatively, lower hardwood prices in Texas could serve to make the proposed action financially unattractive at least in the near time frame. Recent trends in hardwood prices in roundwood form (unchipped and with bark) delivered in the U.S. South Central Region show a decrease of $9 \%$ between 1995 and 1996 (Woodfiber Report 1996).

The assessment team conducted its own analysis of the truck hauling alternative to determine how it compares to the Simpson proposed action. However, without having factor input costs and related assumptions (specific transport distances), and capital investment costs (e.g., the Ensenada Nana Juana barge terminal and transfer deck in Bahia de Amatique), only a partial analysis could be done to estimate how much more expensive the truck alternative would be over the proposed action. The assessment team's analysis involved making a number of assumptions with the goal of trying to estimate the net difference in cost between river and land transport. The cost of the truck alternative tends to be more expensive because hauling distances are much greater, barging is less expensive than the truck hauling on a ton-km basis, and port costs must be paid. However, these costs are offset by not having to construct or install a number of facilities-a barge terminal on the Rio Dulce, navigation aids, and a transfer deck barge facility in the Bahia de Amatique. 
The results of the cost analysis are shown in Table 4 along with key assumptions. The difference between the two alternatives is about $\$ 12$ ton, which is slightly higher than Simpson's estimate. The major cost difference between the two alternatives lies in the use of the Puerto Santo Tomas facilities. Port costs were quoted at $\$ 11.80 /$ ton.

Table 4. Comparative cost analysis of the proposed action and truck transport to Puerto Santo Tomas

\begin{tabular}{lll} 
Description of assumptions & Truck haul to Puerto \\
\hline
\end{tabular}

- Truck costs

- Haul rates - $\$ 0.14 /$ ton-km (10-ton truck) for the proposed action and $\$ 0.10 /$ ton-km (30-load) for the truck haul alternative

- Weighted average haul distances $8 \mathrm{~km}$ for the proposed action and $75 \mathrm{~km}$ for the truck haul alternative

$\$ 1.10 /$ ton

$\$ 7.10 /$ ton

- Barge haul

- Total distance $50 \mathrm{~km} @ 15 \%$ of the O\&M of trucks

$\$ 0.70 /$ ton

- Pusher tug @\$610,000 and 16 hopper barges@\$225,000

$\$ 2.20 /$ ton

No cost incurred

- Investment and O\&M-costs associated with Ensenada Nana Juana barge terminal and other infrastructure $(\$ 5,400,000)$

$\$ 2.80 /$ ton $^{a}$

No cost incurred

- Port costs-(Lopez 1996)

- Carga en entrega directa c/c navieraQ59.26/ton and Muellaje c/c usuarioQ12.10/ton $(\mathrm{Q} 6.06=\$ 1.00)$

No cost incurred

$\$ 11.80 /$ ton $^{b}$

Approximate net cost difference between the proposed action and truck haul to Puerto Santo Tomas

$\$ 12.10 /$ ton

This estimate is based on an estimate of $\$ 5,400,000$ for the barge terminal and other infrastructure. Costs amortized at $10 \%$ and 15 years.

Port costs are subject to negotiation and can be lowered (Lopez 1996).

To improve the viability of the land transport alternative, port costs would have to be reduced. According to port authority officials, these costs are subject to negotiation (Lopez 1996). Greater efficiency in hauling logs would also have to be made by improving land surface routes and, perhaps, considering some form of preprocessing or more efficient loading/unloading technology (e.g., hopper containers to take advantage of port facilities). However, without such cost reduction the land transport alternative is significantly more expensive than Simpson's proposed action. 
Information was not available to estimate the net cost of relocating the barge terminal to either side of Lago de Izabal. It is likely that a terminal(s) would cost less on Lago de Izabal, but require additional costs for roads, power lines, and, possibly, lake dredging.

\subsubsection{Employment Impacts}

Simpson currently employs and/or contracts with about 600 people. Once harvesting operations begin next year employment will double. This employment is directly attributable to Simpson's operations. Typically, direct employment will generate a number of indirect and induced jobs. Simpson assumed that each job directly created would generate another job indirectly (Forestal Simpson 1996). These jobs could be in any number of endeavors, such as suppliers of parts, chain saw repair services, and others. Total employment attributable to Simpson could reach 2400 (Table 5). If Simpson decides to double the size of their operations from their current plan for 10,000 ha of plantation area, total direct and indirect employment could increase to over 5000 . Employment for the alternatives to the proposed action should be approximately the same.

Table 5. Projected direct and indirect Simpson employment under current total plantation area and potential plantation area due to expansion

\begin{tabular}{lccc}
\hline & Pre-harvest & \multicolumn{2}{c}{ Post-harvest levels } \\
Employment & levels & $\mathbf{1 0 , 0 0 0}$ ha & $\mathbf{2 0 , 0 0 0 ~ h a ~}$ \\
\hline Direct employment & 600 & 1200 & 2700 \\
Indirect employment & 600 & 1200 & 2700 \\
Total employment & 1200 & 2400 & 5200 \\
\hline
\end{tabular}

Source: Forestal Simpson (1996).

By comparison, tourism employment comes from hotels, restaurants, tourist shops, and recreation and ecotourism related activities. Employment is also generated indirectly by service industries, stores, agriculture, transportation providers, construction, etc. A rough estimate often used is to assume that the number of direct jobs generated by tourism is proportional to the hotel rooms available to tourists (Belisle et al. 1982). This ratio averages about two jobs per hotel room. The ratio could be higher in the Rio Dulce area because of the potential ecotourism and recreational activities that exist outside the confines of the hotels. INGUAT estimates that there are about 177 rooms suitable for tourists in Puerto Barrios, 62 tourist rooms in Livingston, and 82 rooms in the Fronteras area. In total, there are about 320 hotel rooms considered suitable for tourists within the Rio Dulce corridor. Assuming two jobs for each tourist room would place direct tourist employment (i.e, hotels, restaurants, bars, etc.) at 640 . If it is assumed that each direct job creates one indirect job (e.g., taxis, shops, recreation, etc.), then total tourist employment (direct and indirect jobs) could be on the order of 1250 jobs. This is slightly more than Simpson's pre-harvest employment based on a total plantation area of $10,000 \mathrm{ha}$, but less than the 2400 jobs projected once harvesting operations begin. Of course, the further development of tourism and ecotourism in the Rio Dulce corridor would expand employment levels. A distinct appeal of ecotourism is that it can create jobs in rural areas that have not generally benefitted from economic development programs. The assessment team has no basis on which to estimate the potential impacts of Simpson's proposed action on tourism employment within the Rio Dulce corridor.

\subsubsection{Income and Government Revenues}

Simpson has invested approximately $\$ 20$ million in the local economy in the establishment of 7500 ha of gmelina. Thirty percent of this amount has gone to the purchase of equipment, construction, and purchases 
and rental of land. Seventy percent has been spent on operating expenses and worker wages. In 1997, Simpson plans to invest $\$ 5.4$ million in the construction of a barge terminal and other infrastructure. They will also begin spending $\$ 4$ million for harvesting and $\$ 2$ million for replanting based on a plantation size of 10,000 ha. Simpson's total direct spending will be about $\$ 6$ million annually once harvesting begins. The impact of Simpson spending on the local economy will consist of the direct impact (e.g., wages, purchases of fuel, equipment repairs, etc.) plus the indirect impacts from businesses buying supplies and services as well as the induced impacts from employees spending their wages to buy goods. The assessment team did not have sufficient information to estimate the magnitude of the indirect and induced spending.

Results of the most recent tourist surveys for the Department of Izâbal and the Rio Dulce place annual visitation at 86,600 people. This annual visitation is projected to increase by $50 \%(128,000)$ within the next ten years, and with planned improvements in tourist infrastructure (e.g., airports, roads, hotels, ecotourism activities, etc.) could double from the present 86,000 to 171,400 .

Tourist expenditures are the money visitors spend on hotels, food and beverages, gift shops, local transportation services, entertainment, and various recreation and ecotourism activities. According to recent INGUAT estimates, the amount spent per tourist in the Rio Dulce area is low-no doubt due to a relatively short visitation period and lack of organized tourist/ecotourist infrastructure. However, the amount of spending by tourists is projected by INGUAT to increase from the current $\$ 110 /$ tourist to nearly $\$ 600 /$ tourist in the year 2006. For the current level of Rio Dulce visitation, nearly $\$ 10$ million dollars, is added by the local economy by tourists. If INGUAT's projections are accurate, tourism could be generating significantly higher revenues and perhaps an order of magnitude higher in the next ten years, especially if the tourism infrastructure improves.

Direct tourism spending generates indirect impacts from hotels and restaurants buying goods and services and the induced spending by tourism industry workers. How much of tourism spending contributes to GDP of Izabal's economy is difficult to estimate. In small open economies dependent on foreign production of goods and services to supply the tourist industry, there can be a high degree of "leakage." Lindberg and Enriques (1994) report that $45 \%$ of tourist spending leaks away in Costa Rica and as much as $60 \%$ in Belize. The relatively high degree of leakage reflects the fact much of the tourist spending goes for the purchase of imported goods and services. Due to insufficient information availability, the assessment team did not attempt to estimate the magnitude of the indirect spending resulting from tourism. However, a modest increase in per capita tourist spending and visitation would increase significantly tourism's contribution to the local economy.

The local and national governments also benefit from tourism in the form of taxes and non-tax income collected. These government receipts include the tourist cards, boat inspection fees, boat fees, hotel taxes, and income taxes from tourism employees and tourism companies. No data are available to estimate the magnitude of these government receipts. As with employment impacts, there is no basis on which to estimate the potential impacts that Simpson's proposed action or any of the alternatives might have on tourism and ecotourism.

Finally, the Rio Dulce Master Plan calls for the protection and development of the region as a national park and center for ecotourism. The income generated from tourism by the local economy and the revenues received by the local and national governments represent only one part of the total value of the Rio Dulce. In addition to these direct use or financial values, the Rio Dulce National Park, also provides other measures of value that are not captured in market transactions. These other values include: the functional values the Rio Dulce provides for soil and watershed protection, numerous ecological values, option values based on future personal use, bequest values based on future generation use, and, perhaps, existence values based on 
preservation of the natural environment. Although methods exist to quantify these non-market use and nonuse values, doing so was well-beyond the scope of the ELA team's mission.

\subsubsection{Working Conditions, Transport, and Safety}

\subsubsection{Working Conditions}

Forest harvest operations are known to be extremely hazardous compared to most other jobs. Injury rates are slightly lower than for construction but may be considered in a similar hazardous class. The Simpson harvest operations call for felling $20 \mathrm{~cm}$ trees with chain saws provided by contracted felling crews. Trees will be cut into sections and debarked by hand using machettes. These sections will be hauled by farm tractors to waiting 10-ton trucks which will presumably be loaded by grapple knuckle-boom loaders. In such areas where many chain saws are operating, many trees are being felled, machettes are being used, and tractors are operating, field worker safety is a key concern. Field conditions will generally have gentle to flat slopes but weather conditions may at times be quite wet and muddy. These conditions suggest a hazardous environment where serious injury can occur. Safety standards enforced by Simpson were not raised, discussed, or offered during the team visit to the Rio Dulce. These standards will be extremely important in determining the safety of the working environment in the field during harvesting. Similar safety concerns apply to field workers involved with controlled burning of slash during the preparation activities.

During site preparation, planting, and harvesting field teams must rely on housing, sanitary facilities, and water supplies provided by Simpson, especially in more remote areas. These facilities and supplies can quickly deteriorate if not adequately maintained or designed. The potential impacts to people, land, and water is sufficient to raise as an issue. Reasonable measures should be taken to maintain safe, sanitary conditions for field workers, and protect the environment.

\subsubsection{Transport}

The proposed action by Simpson has the potential to set a precedent for the use of the Rio Dulce by largescale non-tourism commercial traffic. The proposed use of Ensenada Nana Juana also has potential to increase the congestion found on roads in and around the Rio Dulce bridge and to impact the growth of ecotourism.

The barges being considered by Simpson are standard river hopper barges with dimensions of nearly $60 \mathrm{~m}$ in length and greater than $10 \mathrm{~m}$ in width. The presence of the barges has the potential to impact the local cayuco fisherman and create serious safety hazards with pleasure craft if they happen to be motoring at high speed in the canyon area.

The proposed action, the land transport alternative, and the relocation of the barge terminal do not address the congestion problem and the need for efficient tourism access at the Rio Dulce bridge. Simpson truck traffic would increase the congestion through Fronteras and over the bridge. Also, the trucks would be moving throughout the day and could impact aesthetics (visual and noise) and possibly biodiversity. A dual terminal facility alternative suggested earlier is one solution to the potential congestion problem.

An important tradeoff emerges between the use of the Rio Dulce for movement of barges (regardless of the location of the terminal) and use of the Rio Dulce bridge. Foreclosing the use of the Rio Dulce necessarily means that the Rio Dulce bridge must be used to move logs from the north-side plantation sites to Puerto Santo Tomas. Allowing the use of the Rio Dulce for barge traffic can avoid congestion at the bridge only by opting for dual terminal facilities. The decision by Simpson to locate plantation operations on both sides of 
the Rio Dulce and Lago de Izabal, especially the north side, imposes very limiting constraints to costeffectively moving logs and minimizing environmental impacts.

For the viable alternatives identified, only the truck haul to Puerto Santo Tomas would avoid the potential safety concerns with the use of barges on the Rio Dulce. The truck congestion in and around the Rio Dulce bridge along with the accidents that are likely to occur could be avoided with the use of dual terminal facilities.

\subsection{LAND AND SOILS}

The ongoing activities of Simpson involve the following uses of land:

- The use of 9,000 to 15,000 + ha of land outside the land use zones of the Rio Dulce National Park which have been converted principally from cattle grazing to 5-6 year rotation monocultures of gmelina trees;

- Support facilities for production and/or storage of materials and equipment(e.g.,nurseries and storage sheds);

- Use of new, upgraded, and existing roads for transport of materials and equipment; and

- Terminals for staging transport equipment as well as the loading/unloading of wood and possibly other materials.

Each of these activities involves use of land which could affect community development by potentially increased traffic congestion and the added services needed to support direct and contracted activities of Simpson. The principle areas of land use concern are described below.

\subsubsection{Plantations}

The environmental effects of plantation management on soil, nutrient/chemical movement, and hydrology are becoming well documented (Ranney and Mann 1994; Stjernquist 1994; Rijtema and de Vries 1994; Ericsson 1994; Couto and Betters 1994), but somewhat less so for gmelina plantations. No information specifically addressing gmelina plantations in Guatemala is available, thus inference is made from experience and references to other regions.

Simpson has taken action to improve short and midterm productivity of sites on which they have planted gmelina. This has involved three key factors. The first and foremost is the selection of sites appropriate for gmelina and amenable to management practices. Simpson (1996) states that selected sites must be of acceptable cost and previously used for pasture of farming. The second is the source(s) or genetic make up of the gmelina trees to be planted. This involves matching tree needs for nutrients, water, and soil structure with site conditions. Selection of gmelina sources with deeper root systems is an example. The third consists of the management practices themselves. These include addition of appropriate fertilizers, cultivation (soil structure management), soil moisture management (drainage or bedding), control of vegetative competition, and confinement of erosion to acceptable (sustainable) levels.

Soil structure, soil organic matter, and soil pH (and cation exchange capacity which is closely related to site productivity) will be affected by the plantations. In each case the effects are considered environmentally positive. Soils converted from grazing to short-rotation plantations become less compacted and better structured with the removal of cattle and with the combined action of tree root penetration, initial site preparation, and increased soil organic matter. The effect on structure and organic matter, especially deeper than $20 \mathrm{~cm}$, will occur over several decades. Organic matter $(O M)$ in these well drained tropical soils will not 
increase dramatically but the development of a litter layer built up by tree leaf fall will contribute to greater soil OM.

Several studies (Sopper 1980; Wang 1994; Kowalik and Randerson 1994) have found that short-rotation plantations effectively take up heavy metals and heavy loads of nitrogen. Since several heavy metals have been detected in Lago de Izabal sediments, they may have originated from the surrounding landscape as a natural soil component, although this is not confirmed. Plantations offer a safe (non-food source) use of this land and may provide some remediative value in the process. If policies and economics were favorable, it is likely the plantations could provide a valuable community service in the disposal of municipal wastes while (a) remediating waste contaminant problems, and (b) further stimulating growth of the plantations. Additions of fertilizers, pesticides, and any herbicides on the plantations offer little to no threat in emissions to groundwater, surface runoff, and neighboring landscapes.

Fire has been used by Simpson in site preparation for gmelina plantations by the burning of slash resulting from clearing. Fire eliminates slash to make tree planting safer and cheaper; it temporarily eliminates unwanted plants; and it releases nutrients back to the soil. Burning also emits particulates and greenhouse gases to the atmosphere which, for the most part, are again pulled from the atmosphere as the newly planted trees grow. Methane and nitrogen oxides emitted during fires are not so easily removed from air by growing trees. Fires, along with the destructive appearance of cleared land to the untrained eye, could be perceived as a detriment to aesthetics and tourism on occasion but these effects are of low impact.

As practice has shown, fire can escape control to burn range, forest land, and houses. The causes of fires getting out of control are quite numerous and fall into categories of poor planning or preparation, accidents beyond anyone's control, and unpredictable changes in conditions such as gusts of wind on a calm day. Fire is an excellent land management tool when used under the proper conditions and with appropriate preparation. It is not suggested that use of fire be curtailed, just carefully managed and contingencies developed.

Applications of N, P, K fertilizer are not large because they are expensive and would not be cost effective as measured in returns from increased growth. However, additions at about $250-300 \mathrm{~kg} / \mathrm{ha} \mathrm{N}$ one or more times per rotation are significant enough, along with other natural inputs (atmosphere deposition, soil weathering, and soil microorganism activity) to approximate a balanced nutrient budget in the short term. Yet the additions are small enough to avoid significant groundwater or surface water contamination.

Nutrient removal and replacement evaluations can reveal some broad nutrient balance concerns although the usefulness of such evaluations is limited. The nutrients evaluated are easily replaced using agricultural fertilizers. Balances are prone to error due to lack of sufficient information on atmospheric inputs, soil microbial processes, and soil parent material weathering rates. Also, other important soil and fertility processes including $\mathrm{pH}$, buffering capacity, cation exchange, and soil porosity which are more important to long term productivity are not usually captured.

The concern for long term maintenance of site productivity is as important to Simpson as it is to the local community. It is also very difficult to predict because changes tend to occur in small increments often lost in the natural fluctuation of monitoring data. Practically all gmelina plantations have been planted in the past 20 years making long term productivity issues unclear. Simpson as with all others must monitor sites closely. Just as with any crop, managing sites for a target crop may enhance some aspects of general productivity and limit others. Based on other short-rotation tree plantation species, concerns for changes can be grouped into several areas: 
- groundwater (and effects on soil chemistry),

- removal of selected micronutrients,

- $\mathrm{pH}$ buffering and slow release components in the soil,

- slow changes in soil $\mathrm{pH}$ and cation exchange capacity,

- accumulation of such things as root exudates or particular elements,

- slow changes in soil structure and organic matter, and

- changes in soil microbiota.

There are many unknowns and almost certain risks (as with any crop). In such cases, the most important actions are to monitor closely basic soil conditions beyond $\mathrm{N}, \mathrm{P}$, and $\mathrm{K}$ status, rotate crops where possible, push toward the use of native species where possible, and learn more about gmelina's behavior.

At the present level of knowledge, one can probably assume the following:

- soil organic matter levels will gradually increase after several years of tree growth (desirable)

- soil pH may be expected to rise slightly (desirable)

- soil microbiota should become more diverse (desirable)

- water runoff should decrease (desirable)

- soil N, P, K, Ca, and other major elements found in wood will need occasional replenishment.

These assumptions lead to the conclusion that the gmelina plantation management practices should generally result in an improvement in soil productivity with occasional corrective actions necessary along the way.

\subsubsection{Support Facilities}

The list of chemicals and emissions from plantation support facilities includes waste water (especially from propagation nurseries), used oil and other vehicle wastes, fuel spills, fertilizers which can be spilled or accidentally discharged, and chemical wastes from used containers and washed from application equipment. Solid wastes such as fertilizer bags, broken containers for plants, used tires, and worn out field equipment are also materials that must be disposed in a situation where infrastructures for waste treatment and disposal are nearly nonexistent.

In the operation of tree propagation facilities, waste water is often abundant and contains unusual wastes from plant hormone treatment, other growth stimulants, nutrients, chemicals used to sterilize containers and plants, algae, and human wastes. Inspection of the Simpson propagation system revealed no use of unusual chemicals. In fact, the use of chemicals is kept to such a minimum that concern was expressed about adequately controlling the potential spread of disease among plants. So far, gmelina has proven resistant to many propagation/nursery disease problems. However, propagation facility runoff needs to be tested for contaminant presence and concentration to verify their absence and to justify no treatment of this runoff.

The more important issues around support facilities, especially equipment and storage sheds concern: (a) the potential for dangerous combinations of materials such as fuels, fertilizers, pesticides, and chemicals such as lime; (b) spills of fuels, oils, and chemicals which can cause long-term soil contamination dangerous to human health; and (c) solid waste disposal especially of non-degradable materials such as plastic and rubber. No inspection or description of these facilities was provided by Simpson. Existing conditions, precautionary measures, and remediation or treatment of effects was not determined. This should be assessed. 


\subsubsection{Roads}

From the perspective of land use change and environmental effects, roads are the predominant controlling/stimulating factor for intensive forest clearing, increased population density, and increased commercial and medical infrastructures. They also are a source of concentrated storm water runoff and sedimentation in streams.

The Simpson proposed action calls for the construction of all weather forest roads north of the Rio Dulce Park and across a major tributary of the Rio Dulce. Also proposed is the upgrading of minimal, but graded, existing forest roads to all weather access roads to the plantations north and south of the Rio Dulce. Total length of all road treatments is estimated by the EIA team to be between 5 and $18 \mathrm{~km}$, most of which involves upgrading with 2 to $8 \mathrm{~km}$ of substantially rebuilt or new roads. Perhaps three bridges would be involved. These roads would need to sustain periodic heavy traffic of 10-ton trucks in any kind of weather. Without local government road improvements, the length of road affected would be at the low end of the above estimates. Effects of the road construction and improvements associated with the Simpson proposed action would also be on the low end of the estimates.

From an environmental effects perspective, the upgrading of existing roads and development of new roads must be assessed based on road design and drainage standards. This determines the extent of cuts and fills (disturbed embankments) produced, the extent to which storm water is concentrated and discharged, the amount of silt entering natural streams, and the treatment of natural streams at bridge sites.

According to Simpson, the new roads would be all weather gravel-surfaced and designed to accommodate 10ton trucks at speeds of 40 to $50 \mathrm{~km} / \mathrm{hr}$. Cuts and fills would be moderate but drainage of these roads could be of concern for erosion and stream sedimentation. However, the limited length of road to be constructed or disturbed is relatively small and effects of the added sedimentation to streams would be minimal. This is because storm water runoff and siltation is already at a heightened state. The rivers of most concern are the Rio Chocon Machaca and Rio Cienega to the north of the Rio Dulce bridge.

The effects of Simpson-related road development on community development and reforestation are of most concern just north of the Chocon Machacas Manatee Biotope. Small communities in this vicinity are nearly totally dependent on river access. Providing improved road access would stimulate these communities to grow and increase pressure on nearby natural resources including the Biotope itself and water quality in the Rio Chocon Machaca. This in turn could influence some of the environmental conditions for manatees in the Biotope and Rio Dulce National Park.

The proposed action involves approximately 100 round trip truck trips/day ( 5 days/week, not on weekends) all converging on the Rio Dulce Bridge area. An estimated $60 \%$ of these would pass through the congested Fronteras area and over the Rio Dulce Bridge. It should be anticipated that these trucks would occasionally stop for food, fuel, and servicing. Fronteras and Ensanada Nana Juana should be impacted.

The dense development and lack of organized planning near the Rio Dulce bridge have resulted in congested conditions along the Peten Highway. The area would be further congested with the added traffic of 10 -ton trucks when Simpson begins harvesting plantations north of the Rio Dulce. In certain years, up to 200 passes per day (counting 100 loads per day coming and 100 empty return trips/day) of these trucks would significantly impact an already congested area. 


\subsubsection{Rio Dulce Barge Terminal}

The proposed Simpson action would involve the development of loading and handling facilities at both ends of the Rio Dulce. The upriver facility would involve the construction of a barge docking-loading channel ( $12 \mathrm{~m}$ wide up to $189 \mathrm{~m}$ long), concrete aprons, retaining walls, and a truck staging area at Ensenada Nana Juana. This is near the Rio Dulce Bridge and in the Intensive Use Zone of the Rio Dulce Master Plan. A pier to serve as a barge and tug boat dock is not proposed. Rather, facilities for loading and unloading are planned slightly inland and away from the water's edge off a small lagoon.

Simpson estimates that it would take $15 \mathrm{~min}$./truck to unload the 10 ton trucks and place the wood in a waiting barge. At 100 trucks/day, 5 days a week, trucks would need to be unloaded double file for $12.5 \mathrm{hrs} /$ day if everything works smoothly. It is highly probable that by the end of some days, 20 trucks could be queued and the hours of operation extended significantly. However, the que should not interfere with the Peten highway traffic.

The environmental, non-aesthetic impacts of the terminal near the Rio Dulce bridge and associated activities of truck traffic and handling of logs would occur within the context of the Intensive Use Zone of the Master Plan for the Rio Dulce National Park. The primary concerns would be with the fate of leaking truck lubricants being washed into the Rio Dulce via storm water. At a rate of 100 10-ton wood trucks/day, 5 days a week, and with parking time for each truck of 10 minutes to over an hour, these contaminants could be significant.

Wastes generated on-site by the people involved in barge terminal activity would also be of concern. These wastes would include plastic bottles, oil cans, glass bottles, bottle caps, cans, paper wastes, and human wastes associated with intensively used areas. If proper collection and disposal of these wastes were not available, much of the material would find its way into the river. Considering a minimum 100 truck driver visits/day, and assuming a minimum average $1 / 2$ hour visit per day, assuming 4 permanent terminal staff, considering at least $10 \%$ more visits by non-essential people to terminal activity, and assuming operation only 5 days/week, this small site could host at least 540 people-hrs/week. Although this is just an estimate, the fact remains that the site could be an active formidable concentration of people and activity with associated wastes and impacts.

Fugitive dust, truck exhaust, truck noise, removal of some large trees, and noise associated with moving and dropping logs would also have some effect on nearby golden mantled howler monkeys confined to a very small patch of isolated habitat; however, the extent of the impact is uncertain. In the context of other activities in the area, it is also uncertain that the proposed terminal activity would alter the time to the demise of this particular population of monkeys.

\subsection{SURFACE WATER USE}

Water courses would be used for the staging and movement of materials. Proposed barge traffic along the main Rio Dulce corridor would start with two single barge passes/day (one loaded and one empty) on weekdays (Forestal Simpson 1996). If wood production increases, more barge passes would be necessary. Double barge passes would cut the passes/day in half but this would require more staging of empty and full barges near the upriver terminal. Congestion of the waterway in the Intensive Use Zone could be significantly increased.

The second barge terminal site would be in Bahia de Amatique offshore from Punta Manabique which may soon be designated a nature preserve. The terminal is planned as a barge mooring area, barge load-topping 
area, and loading/unloading area from a sea-worthy barge hauling unit that could carry approximately six roaded commercial barges. Logs would be transferred between barges to top of the loads of the barge being transported to the United States. It is not certain what types of moorings and channel signaling would be involved.

\subsection{AESTHETICS}

The proposed Simpson actions would affect the quality of viewing, hearing, smell, and general human experiences from the river or along the shoreline in the vicinity of the barge terminal. With respect to shoreline activities, the proposed barge terminal would generate several significant undesirable visual and sound contrasts. The significance, acceptability, and mitigation of aesthetic changes require systematic evaluation. Various stakeholders have different responses to the same set of conditions based on such things as awareness and expectations. It is for this reason that reliance must be placed on the Rio Dulce National Park Master Plan for interpretation of acceptable aesthetic experiences. This not only will define the extent of perceived aesthetic change (and its acceptability), it will actually define the components of the aesthetic environment to be considered (i.e., the aesthetic resource being affected). However, the Master Plan is vague with respect to aesthetics allowing diverse interpretations. It is for this reason that the analysis of aesthetic impacts considers the effects of Simpson activities in the context of existing, as well as desired situations.

The aesthetic factors considered important in this evaluation and used to assess aesthetic impact are listed below. The precise location or position of viewing may, at times, affect the importance of these factors.

- the number of viewers and length of time of viewing,

- focus or attention to views,

- sensitivity of viewers, and

- aesthetic incompatibility of the proposed activity

The first two items are subsets to viewer sensitivity (item 3). Items 3 and 4 are of equal weight in estimating aesthetic impact. The input to determination of 4 , aesthetic incompatibility, includes the descripters that define contrasts of the proposed action to both existing and desired characteristics of the landscape. These, and the methodology as a whole, are identified and used in the assessment addressed in detail in Appendix A of this report.

A week long inspection of the Rio Dulce area resulted in the identification of key locations for aesthetic analysis with regard to the proposed Simpson action and alternatives (Table 6). These are based on observed levels of human activity, Master Plan guidance, and assumed expectations of ecotourists. The key locations exist regardless of Master Plan interpretation. The ecotourism experience/view is used as the main measuring stick in the aesthetic analysis because of its dominant economic role and growth potential in the Rio Dulce corridor. Even within this role various interpretations legitimately exist.

Although resource management (e.g., agriculture, forestry, cattle ranching, rubber plantations, etc.) is economically important in the area, it is not dependent on aesthetics for economic viability as is ecotourism. Aspects of resource management activities can lend variation and interest to ecotourism experiences. Just as visitors can be interested in banana plantations, rubber plantations, and ships being loaded with bananas, they can be interested in aspects of large volume tropical plantation operations. Plantation operations can also generate negative aesthetic connotations, especially during harvesting, when large quantities of logs move by with clearcuts in the background (no matter who is responsible for the clearcuts), when loud noises (e.g., log handling and large diesel engine sounds) are generated during quiet times, and when large barges interfere 
Table 6. Key locations for aesthetic analysis

\begin{tabular}{|c|c|c|c|}
\hline Key area & $\begin{array}{c}\text { Aesthetic impact: } \\
\text { viewer }\end{array}$ & limiting condition & Comment \\
\hline $\begin{array}{l}\text { Intensive use area and } \\
\text { proposed terminal. }\end{array}$ & $\begin{array}{l}\text { High:local population } \\
\text { and tourists on the river } \\
\text { and on the shores } \\
\text { opposite and adjacent to } \\
\text { the barge terminate }\end{array}$ & $\begin{array}{l}\text { Over-sized barges, } \\
\text { notch in forest edge, } \\
\text { inconsistent sound }\end{array}$ & $\begin{array}{l}\text { Find alternative location } \\
\text { for terminal }\end{array}$ \\
\hline Golfete corridor & $\begin{array}{l}\text { Medium:tourists on the } \\
\text { lake and shorelines }\end{array}$ & $\begin{array}{l}\text { Mainly viewer } \\
\text { sensitivity; little visual } \\
\text { impact }\end{array}$ & $\begin{array}{l}\text { Proposed activity } \\
\text { permissible }\end{array}$ \\
\hline Chocon Machaca & $\begin{array}{l}\text { Low:Biotope visitors on } \\
\text { the shoreline }\end{array}$ & $\begin{array}{l}\text { None provided; no } \\
\text { Simpson activity in or } \\
\text { through the } \\
\text { Reservation; caution } \\
\text { about tourist sensitivity } \\
\text { in reservation }\end{array}$ & $\begin{array}{l}\text { Barges to stay } 1 / 2-3 / 4 \mathrm{~km} \\
\text { from Biotope, no } \\
\text { flashing lights, and no } \\
\text { Simpson movement } \\
\text { through Reservation } \\
\text { with barges or for } \\
\text { plantation maintenance } \\
\text { purposes }\end{array}$ \\
\hline Rio Dulce Canyon & $\begin{array}{l}\text { Very high:local } \\
\text { population and tourists } \\
\text { on pleasure craft } \\
\text { passing through the } \\
\text { canyon }\end{array}$ & $\begin{array}{l}\text { Nationally important } \\
\text { area, strong viewer } \\
\text { focus, barges out of } \\
\text { scale, magnification of } \\
\text { tug sound, navigational } \\
\text { aids conflict }\end{array}$ & $\begin{array}{l}\text { Smaller barges only, } \\
\text { daily passes (for smaller } \\
\text { barges) }<4 \text { w/o } \\
\text { navigation aids }\end{array}$ \\
\hline Plantation and roads & $\begin{array}{l}\text { Low:local population } \\
\text { and tourists driving or } \\
\text { walking through }\end{array}$ & $\begin{array}{l}\text { Road traffic noises at } \\
\text { harvest, plantations in } \\
\text { large homogeneous } \\
\text { blocks }\end{array}$ & $\begin{array}{l}\text { Break up large planting } \\
\text { blocks with more native } \\
\text { vegetation }\end{array}$ \\
\hline Bahia de Amatique & $\begin{array}{l}\text { Low:pleasure craft } \\
\text { passengers and tourists } \\
\text { on the shoreline }\end{array}$ & $\begin{array}{l}\text { Activity will create first } \\
\text { sizeable visual } \\
\text { structures on horizon } \\
\text { out to sea and next to } \\
\text { future reservation }\end{array}$ & $\begin{array}{l}\text { If possible maximize } \\
\text { distance of moorings } \\
\text { from any land area }\end{array}$ \\
\hline
\end{tabular}

with water recreation and fishing in confined areas. Barge, terminal, and truck traffic used by Simpson would add to the intensity of use and add a new dimension (heavy commercial traffic) to it.

Under the proposed action, the tree line along the river's edge in the vicinity of the proposed terminal site would experience the first major break (notch effect) as a result of terminal construction. Mitigation by planing much smaller trees along much of the notch in place of more mature trees will still leave a notch effect for a decade or more. Further, the lack of a backdrop of trees (as viewed from the river looking directly at the notch) would accentuate the notch against the sky. Professional landscape architects have long been 
aware of the desirability of avoiding notch effects generated from forest cuts and road cuts as viewed from the most critical angles.

Traffic on the roads would be affected periodically by the daily number of 10-ton haul trucks when harvesting begins. This would be likely to affect some aspects of aesthetic experience to road-based tourism and local inhabitants. The proposed activity would involve selected forest roads, both existing and those to be built. It would also affect the Peten highway. Selected alternatives to the proposed action would have much broader effects on traffic between the Rio Dulce bridge area and Puerto Barrios/Santo Tomas.

In addition to assessing the proposed Simpson action on each key section of the Rio Dulce, it is important to consider the overall cumulative impact (Section 4.5 ) and how the least desirable impacts can be mitigated (Section 4.6) at minimum cost to Simpson and other stakeholders.

The following is a summary of findings for the key aesthetic areas of the Simpson proposed actions in the Rio Dulce National Park. See Appendix A for details of the aesthetic assessment.

Results suggest that the proposed terminal location and barge staging area would be quite incompatible with the intensive use zone, recreation, and congestion of the area immediately near the Rio Dulce Bridge and in the Canyon. Modifications or amelioration of incompatible aesthetic elements would not remedy the problem. An alternative terminal location, possibly in Lago de Izabal, would be needed to stay within acceptable aesthetic quality limits.

There is some concern about the potential use of tributaries through the Chocon Machacas Reservation to access land management including plantations and cattle ranching. Any such practice on a commercial scale (i.e., not for household use) should be disallowed due to the objectives of the Reservation as a primitive area. Danger to biodiversity (manatees, etc.) is addressed in another section.

With the exception of the proposed terminal location, the staging of barges in the Rio Dulce Intensive Use Zone near the Rio Dulce Bridge, and moving such large barges through the Rio Dulce canyon and bridge area, the proposed action is generally compatible with the Rio Dulce National Park Master Plan. However, these limitations do not make the proposed actions by Simpson acceptable as presented with respect to aesthetics. Moving the upriver barge terminal to Lago de Izabal, limiting numbers, and strict adherence to inconspicuous navigational aids would make the action acceptable.

An aesthetic evaluation of the alternative of barge loading terminals at Lago de Izabal was conducted. The resulting aesthetic impacts were rated as "low." This is a much better rating than the "high" aesthetic impact rating for a terminal in the Rio Dulce Intensive Use Zone.

In conclusion, heavy commercial traffic (i.e., many large barges daily) does not appear to be consistent with the desired or existing overall aesthetic experience of the Rio Dulce. However, very light amounts of barging would not be inconsistent as their effects relate to each zone of the Master Plan.

\subsection{WATER QUALITY AND HYDROLOGY}

\subsubsection{Barge Impacts}

Construction of the proposed barge terminal would require removing vegetation from approximately $30 \mathrm{~m}$ of the shoreline of the lagoon at Ensenada Nana Juana. The principal construction activity would involve 
digging a canal approximately $200 \mathrm{~m}$ long, $12 \mathrm{~m}$ wide, and $3.5 \mathrm{~m}$ deep into the shore for bringing barges into the loading terminal (Forestal Simpson 1996). Significant amounts of sediment would be disturbed and suspended temporarily in the water by that activity.

Industrial and commercial development has already occurred in the immediate vicinity of the proposed terminal site, including a marine service station. Furthermore, the site itself has been previously used as a storage area and camp by the companies that installed the oil line under the Rio Dulce, and constructed the bridge and highway. Therefore, it is conceivable that some amount of contaminants currently exist in the sediments, and could be resuspended in the water by the dredging action (Forestal Simpson 1996).

The construction of the barge loading apron and the other terminal facilities close to the shoreline would also present potential impacts to the water quality of the lagoon and the river through spills or runoff of contaminants and sediment. Employment of the best engineering and construction practices could significantly reduce this potential. Simpson (1996) states; "The impact is temporary and controllable through basic measures of environmental sanitation." Due to the designation of the area as a national park and a center for tourism, greater than minimal measures would need to be employed to prevent additional degradation of the water resources by the proposed action.

Beginning with construction and continuing through the operation of the barge terminal, the site would be a focus of intense activity involving heavy human presence and the use of numerous trucks and other types of equipment for moving the logs. Resulting wastes from these activities could conceivably drain into the terminal canal and subsequently the lagoon. Since no satisfactory disposal system exists in the area, sanitary wastes; spillage from oil changes; oil, fluid, and lubricant leaks; and worn out tires, filters, and other mechanical wastes would require special attention.

Simpson proposes to have the fleet of 10-ton trucks under contract and would not be directly responsible for their maintenance. Thus, servicing and maintenance of 30 to 50 10-ton trucks would be conducted in an ad hoc manner and could involve improper disposal of wastes. These wastes could find their way into the Rio Dulce as an additional pollution factor. To avoid these potential impacts to water quality, Simpson would have to strictly enforce appropriate contractor requirements for equipment maintenance and waste disposal.

Although not currently proposed, the Rio Chocon Machaca and other tributaries of the Rio Dulce could provide access to the gmelina plantations for transport of materials to and from them. Such transport has included fertilizers and seedlings. One fertilizer spill was noted by local inhabitants. Chemical spills and the movement of large quantities of wood are of most concern, predominantly with the Rio Chocon Machaca and the Chocon Machacas Manatee Reservation. The Biotope is clearly off-limits to this and similar activity (such as cattle transport by barge which local residents have noticed). Although this (plantation) activity is not included in the Simpson environmental report, such activity should be clearly eliminated. Concern exists that just as the Rio Dulce is a navigable stream subject to unrestricted use by inhabitants the Rio Chocon Machaca may be considered similarly for heavy commercial barge traffic.

Movement of barges and tugs on the Rio Dulce itself are expected to have little environmental effect on water quality (aesthetics not withstanding). Barge wakes when moving at $5-10 \mathrm{~km} / \mathrm{h}$ are quite small compared to $V$-bottom pleasure craft moving at $25-40 \mathrm{~km} / \mathrm{h}$ and are not an environmental concern to river/lake shoreline erosion or small craft safety.

The movement of barges and the tugboat on the river would produce only minimal impacts by the introduction of new contamination to the water. These could result from leakage of fuel and lubricants from the tug and from drainage of the hopper barge. The latter would occur because rain and surf would 
accumulate through the open tops of the barges and would need to be periodically drained. The drainage could include dirt and log debris (sediment) and possibly nust from the barge hull. This activity could result in temporarily increased localized concentrations of sediments and other contaminants. Existing commercial fueling facilities would be used, thus eliminating the need for additional storage and dispensing facilities.

There is potential for daily churning up of bottom sediment at each end of the barge traverse through the Rio Dulce. The depth of the barge canal constructed at the terminal site would be $3.5 \mathrm{~m}$, and the depth of the lagoon is quite shallow. The draft of both a barge loaded as planned with 900 tons and the twin screw tug is approximately $1.8 \mathrm{~m}$. The churning of twin propellers through the lagoon and at the entrance of the barge terminal could affect water quality by stirring up sediment and associated contaminants on a daily basis. Moderately poor circulation with the main channel may cause disturbed conditions to persist longer in the lagoon than in many other locations and cause significant damage to aquatic life within the lagoon.

On the eastern end of the barge route, a sandbar at the mouth of the Rio Dulce in Bahia de Amatique reduces the water depth to $1.7 \mathrm{~m}$ at low tide. The incoming tide increases the depth by only about $0.3 \mathrm{~m}$. Thus the $1.8 \mathrm{~m}$ draft of the barge and the tug would cross the bar with some scouring of the bottom, and the twin propellers would churn up significant amounts of sediments with any associated contaminants, also on a daily basis. Simpson's contractor MAREX (1996) recommended that the bar "... be dredged to the necessary depth to enable all-season, 24 hour passage of river barges with sufficient cargo capacity to support Simpson's production and shipment schedules." The latest available description of Simpson's proposed action (Forestal Simpson 1996) does not include dredging of the bar. As this area already experiences moderate to heavy use by yachts and other large craft, the Simpson action may represent only a relatively small incremental increase in impacts to existing water quality in the Bay.

An additional incremental water quality impact could result from the proposed barge staging facility in Bahia de Amatique close to Punta de Manabique. Due to the concentration of human activity and mechanical equipment, there would be opportunity for increased concentration of contaminants in the water from leaks, spills, and/or dumping of wastes. Bahia de Amatique already experiences heavy commercial/ industrial use along its shoreline; both Puerto Barrios and Puerto Santo Tomas lie within its confines. Thus it could be reasonably assumed that the expected relatively small incremental input of contamination from the barge staging facility would be insignificant. The exception to that assumption could be the potential for a large spill. However, at the present time, sufficient information is not available concerning the staging facility to allow an assessment of the likelihood or extent of such an accident. The importance of the potential water quality impacts of the staging facility could be increased by the current plans to designate nearby Punta de Manabique as a protected area.

\subsubsection{Plantation Impacts}

The gmelina plantations will affect hydrology and soil moisture within the stands and to some degree modify off-site water movement. Gmelina does not perform well when soils are poorly drained so ditching and drainage has been implemented. Increased forest cover cools soils, increases soil organic matter, and utilizes deeper soil moisture. Furthermore, plantations may also require fertilizers and, for short periods, weed control or pest control (i.e., use of chemicals). Inevitable spills and emissions from cleanup of equipment used for applying chemicals are important considerations.

Gmelina plantations are heavy users of water and require moist but well drained conditions. Their roots are shallow so water tables will be affected only indirectly by the interception of shallow moisture by the trees rather than direct utilization from the water table itself. Changing the use of the land from grazing land to plantations cause small streams to flow more evenly through the seasons and somewhat lower the temperature 
of the water. Effects on lake and river water levels will be minor with any of these effects being considered positive during most of the rotation. Water quality should change to contain slightly less nitrogen known to run off from grazing land.

Most concern related to the effects of the plantations on water quality and hydrology are with the site preparation, stand establishment, and stand harvest periods. This is when the soil is least protected from the elements, when storm water runoff is most problematic, and when the most leaching of soil nutrients into deeper ground water occurs. Based on Simpson's gmelina operation, this period is about 6 months out of every 6 years. All issues considered, the net negative effects compared to cattle grazing over a 6 year period (or multiples of 6) should be so close as to be indiscernible. However, with plantations it is much easier to target the plantation establishment period as the critical period for adherence to good land stewardship principles (best management practices) than any particular practices on grazing land.

Improved road access to some of the more remote villages as resulting from the Simpson operation may generate a significant influx of people. Example towns are El Aguacate and Sumache where present access is difficult. Although the numbers are highly speculative, a net effect of population growth would be likely. This in turn would increase problems of human waste disposal and water purity. Additionally, Simpson field operations involving large groups of employees could generate areas of concentrated human waste and unsanitary conditions if not properly managed and monitored. The company would need to establish wellmaintained temporary sanitation facilities during harvesting and planting.

As Simpson is currently operating plantations both north and south of the Rio Dulce, and are continuing to expand into new areas, the combined effects of all the above actions could impact hydrology and water quality on a regional basis. To avoid significant contamination of surface and groundwater resources of the region, proper waste management methods must be employed and followed up with regular monitoring and maintenance.

\subsection{BIODIVERSITY}

The EIA team found no evidence that Simpson barging operations on the Rio Dulce would significantly impact any species of fish or other aquatic biota other than the manatee. Therefore, the following sections focus on the potential impacts of the barge operations on the populations of the manatee and the howler monkey. Regional effects of the gmelina plantations are also addressed.

\subsubsection{Barge Impacts}

\subsubsection{Manatee}

There are two populations of manatees in the vicinity of the proposed Simpson activities. The larger population of about 40 manatees utilizes the Polochic Reservation at the west end of Lago de Izabal. An illdefined smaller number utilize the shallow aquatic habitat of the Chocon Machacas Manatee (Biotope) Reservation. Past estimates for the total of both populations have been as high as 90 to 100 but uncertainty exists on present numbers. Both populations occasionally pass through the Rio Dulce canyon in their movement between the two aforementioned habitats and coastal Belize habitats. Those manatees utilizing the Polochic Reservation must also pass through the narrow area of the Rio Dulce underneath and east of the bridge. Marine biologists have raised questions as to the minimum number of animals required to maintain healthy manatee populations in view of the small size of these two. The effect of commercial barge traffic and tug boat propellers is likely to have very little direct effect on the population. Manatees are shy of human 
activity but slow in their ability to move away from fast moving boats. The slow movement of commercial barges should make easy their escape although the size and draft of the barges may offer some added concern. With the small manatee populations, the loss of a single individual is important to the population. In this case an infrequent or unusual injury to a manatee is still a significant event.

Of more concern than the proposed barge traffic up and down the Rio Dulce is the potential commercial use of the bays of the Chocon Machacas Reservation and the Rio Chocon Machaca itself for plantation-related activities. As stated earlier, this is not part of the proposed action, but such activities have already occurred and may be implied. Such activity anywhere within the Reservation would pose high risks to the local manatee population. These risks stem from the potential for habitat disturbance as well as direct injury to the manatees. Habitat in this case is concerned with water quality (as affected by fertilizer spills) and physical damage to shallow aquatic shoreline plants.

The management of the plantations themselves should cause no perceptible effects on the manatee habitat and could actually help it to a small degree. However, nunoff, pollution, and chemicals from upstream on the Rio Chocon Machaca beyond the Reservation and plantations are causing sufficiently large impacts to the river's dynamics to mask any positive or negative effects of plantation management. Broader watershed management issues are involved.

\subsubsection{Colden Mantled Howler Monkey}

Within the Rio Dulce National Park there exists one small population of golden mantled howler monkeys. This is slightly east of the Simpson proposed barge terminal in the intensive use zone in an area known as the Marimonte Reserve. According to Brown and Curdts (1988), the population of the group was in the mid teens, a normal sustainable group for the species. Present numbers are believed to be less. The trees to be cut down to make way for the proposed barge terminal should not affect the habitat for the monkeys. However the area used by the monkeys borders the same lagoon in which the terminal would be located. The activity of the tugs, the truck traffic, the sounds of logs being moved, the movement of barges nearby will add to existing water and land traffic now surrounding the isolated habitat. Any effects will likely be neutral or negative. However, these will be lost in the cumulative intrusion of development on the monkey population.

\subsubsection{Gmelina Plantations}

There exists no direct information on biodiversity in gmelina plantations in Guatemala. Nor was any located for Central America. As a result, biodiversity research on short-rotation tree plantation monocultures is used as a substitute. Results are drawn from Eucalyptus, Populus, Liquidambar, and Platanus plantations of short-rotation. Results from Pinus plantations are significantly different from broadleaf plantations and should not be used as a substitute for them.

Based on Couto and Betters (1994), plantations have less diverse fauna than indigenous forests; plantations of exotic species have less diverse fauna that plantations of indigenous species; plantations can be made more favorable for biota using modified silvicultural practices; and planting treeless areas provides shelter that would otherwise not be available to fauna populations (Poor and Fries 1985; Loyin 1985). In Brazilian eucalyptus and araucaria plantations, leaving some large trees (and/or lengthening rotation) was of considerable benefit to bird and other species diversity. From the forest company perspective, leaving $10 \%$ of the plantation area in native vegetation was desirable compared to planting $1 \%$ of the total number of trees (in native stands) using native species. Intermixing plantations with natural riparian forests, occasional old trees, and backing away from intensive silvicultural practices like weeding, cultivation, and herbicide 
spraying benefits fauna diversity. Spacing trees to enable some understory development after crown closure is important.

\subsubsection{Birds}

Studies by the Audubon Society (Hoffman), the USDA Forest Service, the University of Minnesota (Christian et al 1994), Brazil (Couto \& Betters 1994), and the Swedish University of Agricultural Sciences (Gustafsson 1994) on bird use of short-rotation hardwood plantations have yielded essentially consistent results. These results indicate that the plantations provide habitat to groups of species considered generalists, edge species, and limited interior forest species (Sage and Robertson 1994). The groups do not include open field species (except in the first year) or some deep interior forest species. Rare or endangered species have been observed in exotic short-rotation plantations provided the species made uses of similar habitats anyway. Results are heavily influenced by adjacent habitat such as open field, mature forest, and weedy recently abandoned areas and fencerows. Total bird diversity is usually between that of fields and forests. Diversity and composition change significantly with full canopy closure of trees and attainment of about 8 meters tree height. At this point, bird diversity takes on more characteristics associated with forest habitat than field and fencerow habitat.

Based on these findings, the Simpson gmelina plantations should attain some forest habitat characteristics by age 2 or 3 favorable for other than open field birds. The near-forest habitat condition is considered the most helpful for desired bird species. This should mean that roughly half the Simpson plantations at any one time offer helpful bird habitat for the region. The plantations are unlikely to offer much for rarer interior forest bird species. These implications have some serious qualifiers.

The first of these qualifiers is that the plantations lose bird diversity inversely to the purity of the monoculture. This means that fencerows, small stands of native vegetation, and development of understory vegetation, especially advanced understory, play an important role in the interior of larger plantations in providing adequate habitat for birds in the generalist and forest groups (Berndt 1992; Avery 1989; Berndt 1993).

The second qualifier is that very large blocks of plantation, especially of the same age and species, minimize habitat variation required for meeting the various living needs of birds. Studies have only recently been conducted to determine if short-rotation plantations provide productive habitat for any of several uses (nesting, territory, feeding, shelter/resting) as determined by bird usage. Results depend on several factors including the particular bird species, the age (height) of the stand, and the conditions of the understory (e.g., thick herbaceous understory, thin herbaceous understory, no understory except leaf litter).

The Simpson plantations occur in large tracts some of which have few fencerows, natural vegetation corridors, or intervening vegetation. Further, their understory is extremely clean (very little understory vegetation). Because of this, usually only the edges of the plantation offer beneficial habitat for bird diversity. The plantation interiors probably take away habitat for open field bird species but may also do so for generalist species. Actual field data from the plantations are needed to verify any of these conclusions all of which are based on findings in very distant plantations.

\subsubsection{Soil Fauna}

Plantations in general, when displacing grazing land in previously forested environments, increase soil organic matter, reverse soil compaction caused by cattle, reduce the amount of leached nitrogen (in ammonia form), cause a reduction in maximum soil temperatures, and generate a nearly permanent leaf litter layer. In 
the process, fewer plant species provide less of a variety of food for phytophagus soil fauna. All this generally creates a favorable soil environment for much more diverse soil fauna and increased soil fauna biomass compared to intensive agriculture and grazing. Studies at the University of Munich (Makeschin 1994) are the best to have examined soil faunal changes due to plantations. Soil fauna increased in diversity with establishment of plantations on cultivated fields and pastures. Fertilizer applications helped increase microbial biomass. The species taking over in the plantations were of forests and not grasslands. Beetles were seen to decline in some cases due to loss of the variety of food (leaves) (Makeschin 1994) but increased in other studies (Kopeszky 1987). These species provide a food base for other selected species and so can be important in indicating overall biodiversity change. The same would be expected of the gmelina plantations although soil organic matter content measurements need to be taken and soil fauna need to be directly inventoried.

\subsubsection{Small Mammals}

Studies on small mammals in plantations at the University of Minnesota have been very difficult to interpret. This is because many of these species are so specialized in habitat preference that (a) plantations may enhance habitat for some species but not all, (b) occurrence (traveling through) versus utilizing the habitat for life support has been difficult to separate, and (c) minor changes in age, understory conditions, and neighboring habitat influence results significantly.

For the most part, small mammals only utilize edges of plantations and up to 3 to 4 rows of trees into plantations. They will travel into plantations along very minor edges as might exist between two stands of the same species with only a minor age difference. It is also likely they are foraging for food but do not reside in the stands. Again, development of understory vegetation can modify this (Rochelle and Brunnell 1979).

The contribution of the gmelina plantations to smail mammals is probably negative on number of individuals and about the same on biodiversity compared to grazing land with intermittent natural vegetation. This is based on edge habitat per unit area, amount of food, and diversity of habitat. There has been little documentation on the role of plantations in affecting nuisance species such as rats.

\subsubsection{Large Mammals}

Short-rotation plantations are known to provide added cover and attractive avenues of travel for large mammals such as deer in agricultural landscapes (Iowa State University). Browsing of the growing tips and leaves of young trees suggests that larger mammals make frequent use of young plantations as a food source.

\subsubsection{Insects}

The only known studies on short-rotation plantation insect diversity is in Brazil and examine Lepidoptera (butterflies) and many other insect families in eucalyptus. Although the specific reference cannot be cited, diversity was much higher than anticipated. It is not know if this diversity was a result of interspersed natural stands among the eucalyptus or was strictly dependent on the eucalyptus stands themselves.

There are two perspectives on insect diversity in short-rotation hardwood plantations. Ecologists usually contend that diversity must be low because of the low variety of vegetation and habitat in pure monocultures. This may vary if natural understory vegetation is present or substantial natural vegetation tracts adjoins the plantations. 
The second perspective is that of the entomologist responsible for pest control in plantations. Every conceivable pest and damaging insect seems to arise suggesting that diversity, or at least outbreaks of limited insect species in large numbers, is waiting to occur at any particular moment. The truth is likely somewhere between these two perspectives. Insects are known to occur in the gmelina plantations of Guatemala. These include leaf-cutter ants, various caterpillars, diptera (flys), coliopter (beetles), and so on. However, a moment's listening in a gmelina plantation compared to that in a nearby rainforest clearly conveys the much greater insect diversity in the natural forest. Similarities and differences between gmelina plantations and grazing land could not be compared for lack of data. Casual observations suggest than grazing land contains more insect diversity than existing gmelina plantations. However, the plantations could be easily managed to vastly increase insect diversity without significant impacts to stand productivity.

\subsubsection{Pest Species}

A final area of concem is the potential introduction of exotic pests by barge activity. Although none are presently known in the Rio Dulce, the potential exists to introduce pests such as snails and mussels. These have created problems elsewhere in greatly altering habitat and survival for native species.

As yet no serious exotic pest species are known to have invaded the gmelina plantations or affected the Rio Dulce. However, the international exchange of products and movement of transport vehicles raises the risks of introducing exotic pests. The primary concerns are with (a) diseases and pests introduced with exotic tree propagules and (b) exotic aquatic organisms such as snails, mussels, and plants which could invade the Rio Dulce.

Inspection of the gmelina propagation system indicates that no pests or diseases have yet been a problem or threat. Some precautions, although minimal, are being undertaken. These precautions in sterilization of imported and propagated plant materials involve trade-offs between prevention of disease and minimizing chemical emissions used in the prevention process. Simpson is minimizing chemical emissions and yet taking some precautionary steps.

Barge and pleasure craft traffic on the Rio Dulce involve craft that have also been in foreign waters and environments where aquatic and marine pests and diseases could be accidently picked up. So much traffic has already passed through the Rio Dulce that pests could have already been introduced. The reasonable response is to install an aquatic biota monitoring system that would detect the emergence of pest species.

\subsubsection{Regional Biodiversity and Wildife Corridors}

The Rio Dulce National Park and the Chocon Machacas Manatee Biotope are included in a proposed arrangement between biological preserves in the region, the most notable being the Maya Biosphere Reserve. However, there are seven closer preserves and potential preserves now under consideration (Godoy and Cardona 1996). This collection of preserves testifies to richness of the biodiversity in the region and its potential for conservation and ecotourism. The connection of these reserves via ecological (habitat) corridors as drafted by Godoy and Cardona could facilitate the movement and interaction of various species between the preserves. Ecologists believe this would enhance the diversity, survival, and sustainability of species within the preserves.

Most notable among these connecting corridors for Simpson consideration is that along the Rio Cienega and Rio Chocon Machaca which connects the Sierra de Santa Cruz Reserve with the Rio Dulce and Chocon Machacas Biotope. Simpson has existing and planned plantations within the corridor. These corridors are not preserves but very broad strips of land where opportunities are sought in private land management to capture 
occasional habitat conditions that will assist in species movement from one reservation to another. The intent is not to inflict cost or regulation but to inform landowners concerning ways they can help facilitate biodiversity. The landowners decide for themselves what they want to do. The gmelina plantations offer forest cover that, with minor modification, could facilitate connecting corridor objectives. These minor modifications include staggering harvest years for very large single-aged stands, allowing at least one continuous corridor of natural vegetation to cross or border the larger plantations in directions that help connect Sierra de Santa Cruz with the Rio Dulce, and permitting development of some understory vegetation (perhaps as corridors themselves within the plantations) to facilitate the movement and support of biodiversity in/through the plantations.

Present gmelina plantation layouts have not yet recognized these opportunities. Simpson collaboration with environmental NGOs such as FUNDAECO and the Nature Conservancy could capture some valuable opportunities. Without the minor modifications, the plantations probably do not detract from previous conditions of interpreserve connectivity and may provide some improvement over grazing land but this has not been proven.

\subsection{CUMULATIVE IMPACTS}

The proposed Simpson action is one part of cumulative development activities in the area. Direct effects in the form of habitat modification are involved. Indirect effects through the use of chemicals, emission of pollutants, increased human access via forest roads, loud loading noises, and the increased travel up and down the Rio Dulce interact with non-Simpson activities to generate less measurable incremental degradation of biodiversity.

Cumulative impacts have been defined as those impacts that can be identified as resulting from the combined effects of past, present, and reasonably foreseeable future actions. Very often the impacts of a proposed action, when evaluated separately from other activities, appear to be inconsequential. However, when viewed in the context of cumulative impacts, in combination with other past, present, or reasonably foreseeable future actions the impacts may become significant.

In this EIA, the Simpson proposed action could be viewed by some as resulting in relatively small incremental environmental impacts to an area that has already seen extensive uncontrolled development and devastation of natural resources that were abundant 40 years ago. This type of assessment uses the existing environment as the baseline for assessing new impacts. However, McCold and Saulsbury (1996) hold that the use of existing environment as the baseline for cumulative impact assessment is not appropriate. Using this approach makes the effects of past and present actions part of the baseline rather than contributors to cumulative impacts, and limits the assessment to impacts of the proposed action in combination with foreseeable future actions.

Additionally, the Direccion General de Bosques y Vida Silvestre (DIGEBOS), now Instituto Nacional de Bosques (INAB), Master Plan for the Rio Dulce National Park sets a policy for the promotion of ecotourism for future economic development and the protection of biodiversity. Enactment of this policy would require not only the prevention of further environmental deterioration of the region, but also the reversal of the current trends with reclamation and reestablishment of natural resources that are very close to obliteration in much of the area, e.g., the tropical rainforest environment along with habitat for the manatee and the golden mantled howler monkey. When viewed in the context of the Master Plan, cumulative impacts could provide a different perspective. Potential cumulative impacts of each of the five environmental areas addressed in this EIA will be discussed in the following sections. 


\subsubsection{Socioeconomic Resources}

The Simpson plantations are providing jobs for a minimum of 600 people in the area. Simpson estimates that another 600 indirect local jobs have resulted from the boost to the local economy provided by their activities. They have also estimated this number to double with initiation of harvesting. If the Simpson operation expands significantly and/or other companies undertake large-scale plantation development in the region, significant numbers of jobs would be added. Such activities may, however, work counter to the ecotourism plans for the region. The direction and degree of impacts would depend on the level of collaboration, planning, and control that occurs involving both the government and the commercial interests.

The barging of gmelina logs on the Rio Dulce would be a precedent-setting activity that would be attractive to other commercial interests who could benefit from transporting large loads on the Rio Dulce by barge, e.g., diesel fuel for the Exmibal facility and produce from $\mathrm{Panzos}$ on the Rio Polochic. The cumulative impacts of increasing barge traffic could further affect ecotourism plans and could present safety concerns to the local population who use the river heavily.

If current trends continue, tourism will become the largest source of foreign earnings for Guatemala. The potential exists for the Rio Dulce National Park to become an important tourism and ecotourism destination providing income and employment surpassing that of all other commercial activities in the area.

\subsubsection{Land and Surface Water Use}

\subsubsection{Plantations and Support Facilities}

The Simpson plantation establishment practices tend to improve soil quality, and the presence of trees can be viewed as an improvement over the wide expanses of pasture land that have resulted from slash and burn practices. However, the foreseeable continued expansion of the Simpson gmelina plantations would set aside more land (a minimum of 15,000 ha for 15 years) that would not be available for reestablishment of rainforest and habitat for native species. Continuation of present strict monoculture practices could further exacerbate the problem. Although Simpson has not been responsible for the initial clearing of the land that is now being turned into gmelina plantations, the continued expansion of the plantations in combination with the past, present, and foreseeable future practice of destruction of tropical rain forest in the region provides pressure contrary to the Master Plan policy of expanding ecotourism and protection of biodiversity.

\subsubsection{Roads}

The construction of new roads and the upgrading of existing roads for the gmelina operations provide easier access to more areas by the local population. The areas being accessed have, for the most part, been heavily disturbed previously; however, the roads provide pathways for increased development and habitation in areas that were previously mostly uninhabited. Increased availability of roads could serve to exacerbate the other past, present, and future development pressures in the region.

\subsubsection{Barge Terminal}

Past, present, and foreseeable future commercial activities along the Rio Dulce in the vicinity of the bridge have and will continue to have significant impacts on land use in the local area, and on the land use policy set forth by the Master Plan for the park. The barge terminal is a new type of development within the protected area. In combination with many of the other present commercial activities, it would apply pressure in opposition to the ecotourism policy. 


\subsubsection{Aesthetics}

The total aesthetic experience of the Rio Dulce corridor as affected by the proposed Simpson action is of concern to the ecotourism industry. This concern will increase with time if ecotourism expands according to projections. The experience is to be cultural, primitive wilderness, resource extraction (sustainable) on a small or primitive scale, recreation, and both rustic and convenient ecotourism with all the aesthetic experiences related to the wet tropics-a little of everything but each in its own zone.

The aesthetic impacts (visual, auditory, and olfactory) of adding the barge terminal and staged barges to the impacts of other past, present, and reasonably foreseeable future commercial activities at Ensenada Nana Juana would be significant and perhaps unacceptable, particularly from the perspective of the Master Plan for the national park.

\subsubsection{Water Quality}

The Simpson barging activity is not expected to have significant water quality impacts in the main channel of the river. However, every commercial activity experiences inevitable leaks and spills. The addition of the Simpson activity, which includes the potential regular churning up of bottom sediments, to those associated with other commercial activities (e.g., marine fuel station) in the circular water current of the lagoon at Ensenada Nana Juana could result in significant, localized degradation of water quality.

\subsubsection{Biodiversity}

Biodiversity in the Ensenada Nana Juana area has already been severely affected by past development, with many species being entirely removed from the area. The local population of golden mantled howler monkeys is isolated and precarious. The construction and operation of the barge terminal would add another level of intense human presence, the operation of machinery, and the associated noise and other emissions. In addition it would require cutting a gap up to $45 \mathrm{~m}$ wide through the remnant treeline along the shore of the river (Forestal Simpson 1996).

Data are not available to determine whether the Simpson plantation operations are positively or negatively affecting biodiversity on a regional basis. It can be predicted, however, that allowing natural vegetation corridors to develop, particularly along drainage areas and fence rows would have a positive impact on the existing biodiversity.

\subsection{IRREVERSIBLE AND IRRETRIEVABLE COMMITMENT OF RESOURCES}

Permanent loss or commitment of environmental resources resulting from the implementation of an action should be a key factor in decision-making concerning the selection of the preferred alternative. However, in the course of evaluating the context and extent of an impact, the factor of duration can be overlooked. In this section, the impacts that will remain for extensive periods of time, i.e., essentially permanently, will be highlighted.

\subsubsection{Socioeconomic Resources}

A decision to open the Rio Dulce up to construction of the barge terminal and barge transport on the river would be the most financially advantageous from Simpson's perspective and would help solidify the jobs associated with the gmelina plantation operations. However, without controls, such a decision could set a 
precedent for the establishment of commerce on the river that would last for generations (essentially permanently). The commitment of the shores of the Rio Dulce for heavy commercial development could negatively affect the quality of life in the area, but may provide a higher standard of living for some percentage of the population that would work for the companies involved. If the economic future of the region is to be based on ecotourism, as directed by the Master Plan, the construction of a barge terminal and use of the river by Simpson for barging should only be approved in association with enforceable controls that would limit future development and the amount of barging allowed on the river. However, given the lack of resources for enforcement of controls, approval of the proposed action could signal the end of serious ecotourism plans.

\subsubsection{Land Use}

The construction of the barge terminal at the proposed location would permanently place a major commercial development within the protected area and would remove the land in the vicinity from consideration for other types of development such as ecotourism. Conversely, on a regional basis, selected portions of the land currently devoted to gmelina growth could be restored to native vegetation and habitat to provide corridors for native fauna.

The reclamaation of large areas of land can also be accomplished, although it would be limited along the Rio Dulce by rapidly expanding population and development. This process is exemplified by the current extensive forests of the Smoky Mountains National Park in the eastern U.S. The area was largely clear-cut around the turn of the century and much of it was used for years as pasture for livestock.

\subsubsection{Aesthetics}

Once constructed at Ensenada Nana Juana, the barge terminal would present additional permanent visual, auditory, and olfactory impacts to the existing aesthetic impacts of the area, and would affect the lagoon as well as nearby property on both sides of the river.

\subsubsection{Water Quality}

Beginning with construction and continuing through the operating life of the barge terminal (for practical purposes permanently), the water quality in Ensenada Nana Juana would be negatively impacted by churning up of the bottom sediments and associated contaminants by tug propellers and by the inevitable leakage and spillage that would occur at the site over the years.

\subsubsection{Biodiversity}

The impacts of the construction and operation of the barge terminal on the biodiversity potential of the immediate vicinity would be permanent. Unless a concerted effort is waged which would include all stakeholders, current trends may well continue. The biodiversity potential of the plantations could be enhanced by modification of management practices.

\subsection{MITICATION METHODS}

From the environmental perspective (i.e., the Master Plan for the national park), the greatest overall mitigation of the impacts of barging gmelina logs on the Rio Dulce would be obtained by relocating the barge terminal to Lago de Izabal, preferably using both the north and south shores of the lake to avoid traffic 
congestion at the bridge. Furthermore, because the proposed level of barging would set a precedent for commercial use of the river, enforceable limits should be placed on the number of barge trips allowed on the Rio Dulce per day to avoid potential future overuse problems. These two mitigations would allow Simpson to reclaim their investment by proceeding with harvesting and transport of the logs to the U.S.,would protect the environmental integrity of the park, and would improve the safety of the operation.

Additional specific, operational, mitigation methods proposed by Simpson or suggested by the EIA team are presented in this section. All of these would apply to any of the options involving transport by barge and many would also apply to the non-barging alternatives.

- Enforce strict safety standards for all plantation operations (particularly harvesting) and transporting the logs on the river.

- Maintain sanitary living conditions in the field for protection of the workers and the environment.

- Move barges on a predetermined basis with specific route and times.

- Avoid using barges on weekends and holidays.

- Position signs at the mouth of the river and in the vicinity of Ensenada Nana Juana to announce travel times.

- Broadcast barge travel schedules on $\mathrm{CB}$ channel 13.

- Use best practices in constructing and operating the barge terminal(s).

- Maintain and practice spill response plans to avoid accidental contamination of land and water resources.

- Use good waste management and disposal practices.

- Require regular checkup and maintenance for all equipment. 


\section{FINDINGS AND RECOMMENDATIONS}

\subsection{SIMPSON'S PROPOSED ACTION}

- Construction of a barge terminal inside the Rio Dulce National Park would set a precedent contrary to the Master Plan. An option is to relocate barge terminal(s) to Lago de Izabal.

- Movement of barges through the national park could be permitted on a temporary basis (3-5 year period) provided the maximum number of barge round trips per day is limited to 2 .

- Barges should not be moored or staged in the Rio Dulce or its tributary streams, only in Lago de Izabal, if necessary.

- The Puerto Santo Tomas facilities should be reevaluated to determine the actual capability of handling the Simpson work.

- Port costs should be negotiated and a detailed analysis of Simpson construction and operating costs for barging should be conducted to determine whether Puerto Santo Tomas can provide a viable alternative to the staging platform in Bahia de Amatique.

- Gmelina plantations in Costa Rica have recently been certified by the Tropical Rainforest Alliance for acceptability in management and sustainability - this should be sought by Simpson in Guatemala.

- Developments in Amatique Bay should consider the likely designation of nearby land as a protected area. This means special efforts to avoid environmental risks, spills, or long-term degradation of the area.

- Barges should be limited to wood and agricultural products; chemicals, fertilizers, fuel, lubricants, forest equipment, wastes or any toxic substances should be excluded.

- Large commercial barges should not use tributaries of the Rio Dulce below San Felipe Castle.

- Simpson must actively administer pollution prevention measures at the terminal and enforce policies for transport contractors (especially proper disposal of wastes such as crank case oil, tires, etc.)

- Serious efforts must be made by Simpson in cooperation with local authorities to minimize truck traffic over the Rio Dulce Bridge

- Simpson should start developing natural habitat corridors in their plantations, managing remnant habitats (even if they are non-usable wet areas).

\subsection{CONTROL OF REGIONAL DEVELOPMENT}

- Regulations containing detailed environmental limits need to be enacted and enforced to halt the rapid degradation of the natural resources of the Rio Dulce Protected Area and allow reclamation to be begin.

- The number of agencies having responsibilities in the management of the Rio Dulce National Park need to be reduced to one (i.e., a "river keeper"). Others may be involved but should report to the responsible agency. This should eventually save administrative costs that could be directed toward a constant presence in the park, the enforcement of plans and regulations, and the processing of permit requests and violators of regulations.

- Environmental and ecological monitoring is desperately needed to establish baselines from which to assess the health of the park. NGOs and universities should be involved in a monitoring plan.

- Consideration should be given to collection of "park user fees" to help defray costs of monitoring and management.

- Specific plans for rehabilitation of the intensive use area should be developed and implemented to reclaim a more natural setting, to ensure the survival of the local howler monkey population, to improve biodiversity in general, to increase aesthetic quality, and to facilitate the development of ecotourism. 
- The areas around the Rio Dulce bridge (along the river and along the Peten Highway) are in desperate need of community planning, zoning, and waste management. The area is rapidly and haphazardly growing to the detriment of the environment and ecotourism. Increased truck traffic will add to the existing problems.

- Principals of good stewardship and best management practices should be enforced for all extensive land uses in the Rio Dulce watershed. Present practices threaten the environmental quality and biodiversity of the Rio Dulce.

- If the alternative of moving the barge terminal to Lago de Izabal is selected, secondary roads in the Rio Dulce intensive use area and on the north and south shores of Lago de Izabal must be improved.

- Studies should be initiated to look at economic development options that are consistent with the sustainable management of the Rio Dulce Protected Area and National Park. Specific studies might include rehabilitating the rail line, developing a limited access road along the oil pipeline right-of-way, and/or using the Rio Sarstun for commercial, nontourist activities.

- Simpson currently provides some benefits to the community; however, options should be studied for raising revenue from this operation to aid in improving the Rio Dulce National Park, enforcement of regulations, and to assist in community development. 


\section{REFERENCES}

Basterrechea, M. 1991. Evaluation of the Environmental Impacts of Seismic Exploration in the Basin of Lago de Izabal, Guatemala.

Belisle, F., S. Seward, and B. Spinard 1982. "Summary and Conclusions," in Tourism in the Carribean: The Economic Impact, edited by S. Seward and B. Spinard, International Development Research Center, Ottawa.

Bray, L., personal communication, Tennessee Valley Authority, Knoxville, TN, October 2, 1996.

Brown, M. H. and L. T. Curdts 1988. The Marimonte Reserve, Izabal, Guatemala. A report prepared for El Instituto Guatemalteco de Turismo.

Christian, D. P., G. J. Niemi, J. M. Hanowski and P. Collins 1994. Perspectives on Biomass Energy Tree Plantations and Changes in Habitat for Biological Organisms. Biomass and Bioenergy 6(1/2):31-40.

CONAP (Consejo Nacional de Areas Protegidas) 1992. Estudio Technico Proyecto Fase II Izabal, Fundacion "Mario Dary Rivera" (FUNDARY), Agencia Para El Desarrollo Internacional (AID), Conservacion Internacional (CD), and The Nature Conservancy (TNC).

Corets, E. 1995. The Resident and Migratory Birds of Rio Dulce, Izabal, Guatemala, Peace Corps.

Couto, Laercio and D. R Betters 1994. Short-Rotation Eucalyptus Plantations in Brazil: Social and Environmental Issues. A report prepared for Oak Ridge National Laboratory, Biofuel Feedstock Development Program, Bldg 1059, Box 2008, Oak Ridge, Tennessee, 37831. [a good source for references]

Evans, J. 1992. Plantation Forestry in the Tropics. Clarendon Press, Oxford, England.

Forestal Simpson, Limited 1996. Evaluation of Significant Environmental Impact Project for River Transportation of Wood, Guatemala City, Guatemala, October.

General Services Administration 1996. Air Quality Improvement Project Central and West Heating Plant, Addendum No. 1, Visual Impact Analysis Update (in draft Environmental Impact Statement, April 8), submitted to General Services Administration, National Capital Region.

Godoy, J. C. and J. Cardona 1996. Corredores Ecologicos Para La Guatemala, Del Siglo XXL. Published by Comision Centroamericana de Ambiente y Desarrollo (CCAD), Consejo Centroameriçano de Areas Protegidas y Bosques (CCAP-B), and Programa de Naciones Unidas Para el Desarrollo (PNUD). RLA/95/G41.

Hammitt, W. E. 1988. Visual and Management Preferences of Sightseers; in Visual Preferences of Travelers Along the Blue Ridge Parkway (Noe and Hammitt editors), U.S. Department of Interior, National Park Service, Scientific Monograph Series No. 18, Washington, D.C., pp. 11-36.

Herzog, T. R. 1984. "A Cognitive Analysis of Preference for Field-and-Forest Environments," in Environmental Aesthetics: Theory, Research, and Applications (Jack L. Nasar, ed.), Cambridge University Press, Cambridge, pp. 343-356. 
INGUAT (Instituto Guatemalteco de Turismo) 1996. Proyecto de Ordenamiento Territorial y Desarrollo Turistico: Guatemala, Resumen Ejecutivo, Guatemala City, Guatemala, June.

Insituto Nacional de Estadista 1995. Estimaciones de Poblacion Urbana y Rural por Departamento y Municipio, 1990-95, Publicaciones Estabdisticas Temtaticas 2.11.4, Guatemala.

Janzen, D.H.(editor) (?). Costa Rican Natural History, The University of Chicago Press, Chicago, USA, pp. 48-449 (short description of the biology of Alouatta palliata or golden mantled howler monkey).

Kangas, P., M. Shave, and P. Shave 1995. "Economics of an Ecotourism Operation in Belize", Environmental Management, 19:669-673.

Lindberg, K. and J. Enriquez 1994. An Analysis of Ecotourism's Economic Contribution to Conservation and Development in Belize, Volume 2, World Wildlife Fund and Ministry of Tourism and the Environment (Belize), Washington.

Lopez G. C., Personal communication and Rubios Tarifarios en lá Exportacion de Trozas de Madera, Deputy general manager, September 11, 1996.

Machorro, R, M. Basterrechea and P. Goodell 1995. Heavy Metal Pollution Assessment from Sediment Analyses at Lago de Izabal, Guatemala. IN: Proceedings, Second Inter-American Environmental Congress (Vogel, Abdelghani, Valladares, Aguilera, and Chapa editors), Organization of American States, Department of Scientific and Technological Affairs, pp 88-91.

Makeschin, F. 1994. Effects of Energy Forestry on Soils. Biomass and Bioenergy 6(1/2):63-80.

McCold, L. N. and J. W. Saulsbury 1996. "Including Past and Present Impacts in Cumulative Impact Assessments," in Environmental Management 20(5):767-776.

Miller Freeman Inc. 1996. International Woodfiber Report, Volume 2-Number 12, San Francisco, December.

Mussack, M., Personal Communication, General manager, Site Visit to Simpson Plantation Sites, Rio Dulce-Livingston, Guatemala, September 6, 1996.

Nations, J. D., B. Houseal, I. Ponciano, S. Billy, J. C. Godoy, F. Castro, G. Miller, D. Rose, M. R. Rosa, and C. Azurdia 1988. Variedad Biologica y Bosques Tropicales En Guatemala. Center for International Development and Environment, World Resources

Nature Conservancy 1996. Training Department Strategy V, Washington, D.C.

Office of Technology Assessment, U.S. Congress 1993. Potential Environmental Impacts of Bioenergy Crop Production. US Government Printing Office, Superintendent of Documents, Mail Stop: SSOP, Washington, DC 20402-9328. Document ISBN 0-16-042099-7; Background Paper OTA-BP-E-118.

Ranney, J. W. and L. K. Mann 1994. Environmental Considerations in Energy Crop Production. Biomass and Bioenergy 6(3):211-228.

Rijtema, P. E. and dW. de Vries 1994. Differences in Precipitation Excess and Nitrogen Leaching from Agricultural Land and Forest Plantations. Biomass and Bioenergy 6(1/2):103-114. 
Shell 1991. Evaluation of Environmental Impacts, Shell Exploration B.V., Guatemala.

Stjernquist, I. 1994. An Integrated Environmental Analysis of Short Rotation Forests As a Biomass Resource. Biomass and Bioenergy 6(1/2):3-11. 


\section{APPENDIX A}

\section{AESTHETICS METHODOLOGY}

This appendix presents the methodology and evaluation data for estimating aesthetic impacts of the existing gmelina plantation operations as well as Simpson's proposed action of constructing and operating a barge terminal, and moving wood by commercial barges via the Rio.Dulce to Bahia de Amatique.

There exist two points of comparison against which to measure the aesthetic impact of the proposed actions, i.e., there may be two different baselines. The first is the existing aesthetic conditions which have, in some situations, deteriorated over the past few years in the Rio Dulce area. The second is the set of objectives for the Rio Dulce National Park as set forth in a Master Plan. These objectives may differ from existing conditions. The Master Plan objectives with respect to aesthetics are not very specific and are subject to interpretation.

An aesthetic impact worksheet was developed for application in the Rio Dulce area. This form consists of a series of boxes which contain actual field evaluation data. The appropriate data point is circled or checked within each box. Each worksheet applies to only one "area or landscape." The top of the worksheet contains information on the key area name, whether the baseline is an existing condition or results from an interpretation of the Master Plan, and whether the sheet applies to proposed action by Simpson or to an alternative to the proposed action.

A work sheet was filled out for each of 7 key aesthetic areas (Figures A.1-A.9) in the Rio Dulce corridor as identified in the main body of the environmental analysis. Each worksheet shows the inclusion of various aesthetic factors and the way in which they were combined. This sequential, two-factor comparison process ultimately produces an overall aesthetic impact rating. Factors is brought into the comparison process early (i.e., boxes to the extreme left of the worksheets), carry less weight in the overall outcome.

Not all the analysis for a key aesthetic area could be included on a single worksheet. The descriptive aspects of aesthetics are presented on separate sheets. These separate sheets contain several items, including the derivation or definition of the baseline aesthetic in everyday terms. The baseline may be the existing condition or a condition defined by (interpreted from) the Rio Dulce Master Plan as the desired end. This baseline condition is then translated into the basic elements of line, form, color, texture, sound, and smell. These are terms used by artists and landscape architects. Contrasts to these elements as imposed by the proposed action are then defined and rated as strong, medium or weak and checked off on the worksheet (see box titled "CONTRASTS BETWEEN BASELINE AND ACTION"). The overall "INCOMPATIBILITIES" are rated from these separate contrasting elements. After this is done, these physical incompatibilities are compared to view sensitivity with equal weighting.

The factors leading up to view sensitivity are all on the worksheet. The ratings for most key areas are readily identifiable on the worksheet. Definition of several factors (e.g., number of viewers, duration of view, focus of view, and ecotourist (viewer) sensitivity can be found in the reference General Services Administration (1996) and are not presented here. Factors are integrated using a matrix rating approach. This lets the reviewer know how a high rating in one factor might compare with a low rating in another factor. The approach is nonparametric and relative. However, increased numeric precision will not improve the accuracy of the outcome. 


\section{Rio Dulce EIS Aesthetic Impact Analysis}

\section{RoDuke}

Key Area Assessment Worksheet

Area Name Intenslve Use Alex Existing Condition_ $\_$; Master Plan ; Simpson Action $\sqrt{\text {; Alternative Action }}$
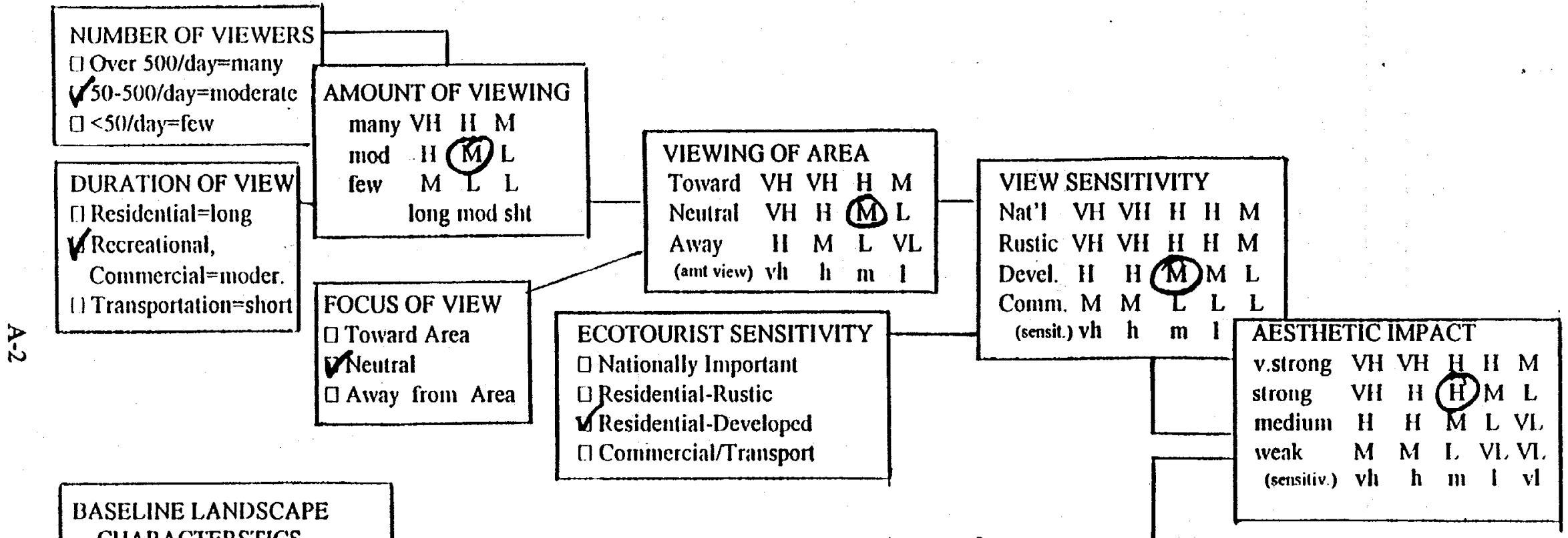

BASELINE LANDSCAPE CHARACTERSTICS Sce altaclicel descriptors (line, form, color, texlure, sound, and smell)

CHARACTERIZED CHANGES BY PROPOSED ACTIONS See allaclied descriplors

(line, form, color, lexture, sound, and smell)

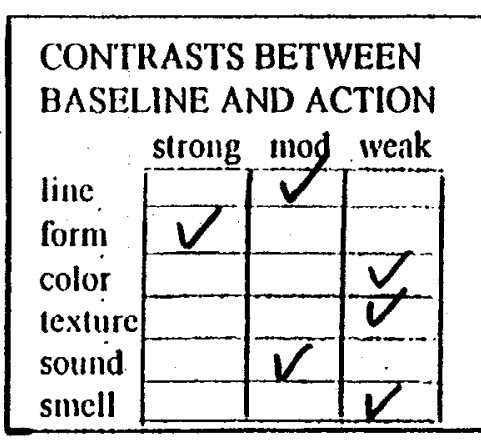

INCOMPATABILITIES

U $>3$ (v. strong)

$\checkmark 1-3$ (strong)

$\square 0$ strong, any med (med)

$\square$ no strong or med (iveak)

Figure A.1

$1 \quad 1$

$1 \quad 1$

1

1

1

1 


\section{RoDuke}

Area Name Tritensive Uke Area Existing Condition

\section{Rio Dulce EIS Aesthetic Impact Analysis}

Key Area Assessment Worksheet
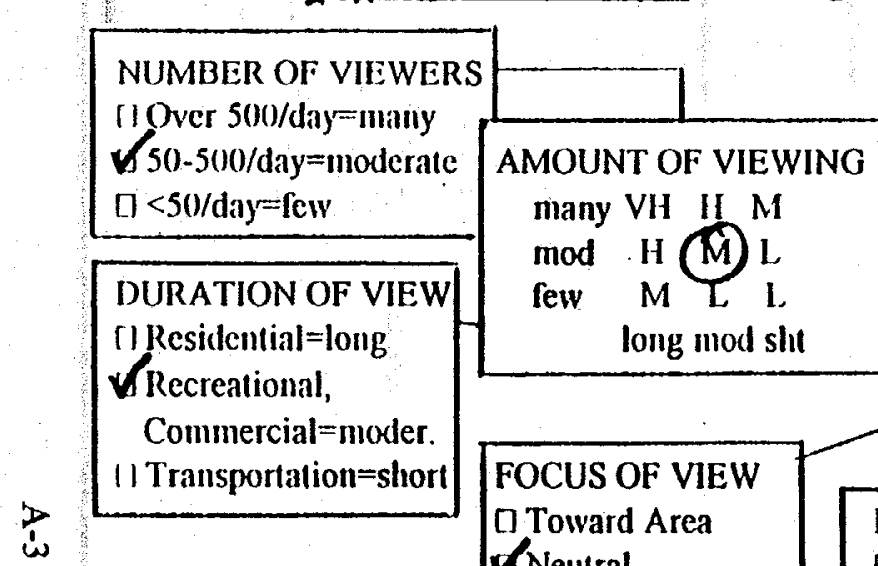

FOCUS OF VIEW

口 Toward Area

Neutral

Q Away from Area

\section{ECOTOURIST SENSITIVITY \\ Q Nationally Important \\ CResidential-Rustic \\ $\square$ Residential-Developed \\ U Commercial/Transpon}

BASELINE LANDSCAPE

CHARACTERSTICS

Sce attaclied descriptors

(line, form, color, lexture,

sound, and smell)

CHARACTERIZED CHANGES

BY PROPOSED ACTIONS

See attached descriptors

(line, formi, color, texture,

sound, and smell).
Master Plan.

\section{; Simpson Action}

\section{VIEW SENSITIVITY \\ Nat'l VH VH H II M \\ Rustic VH VH (1)H M \\ Devel. H H M M L \\ Comm. M M L L L}

(sensit.) vh h $\mathrm{m} 1$ AESTHETIC IMPACT

v.strong $\mathrm{VH}$ VH $\mathrm{H} H \mathrm{H}$ strong VH $\mathrm{H}$ H M L medium $H \quad H \quad M \quad L$ VL weak $M \quad M \quad L \quad V L, V L$ (sensitiv.) vh h $m$ l

\section{INCOMPATABILITIES}

[] $>3$ (v, strong)

$\checkmark 1-3$ (strong)

$\square 0$ strong, any med (med)

II no strong or ined (weak) 


\section{Rio Dulce EIS Aesthetic Impact Analysis}

Golfete
Area NameCorridor

\section{Key Area Assessment Worksheet}

; Existing Condition $\_$; Master Plan

; Simpson Action $\_$; Alternative Action
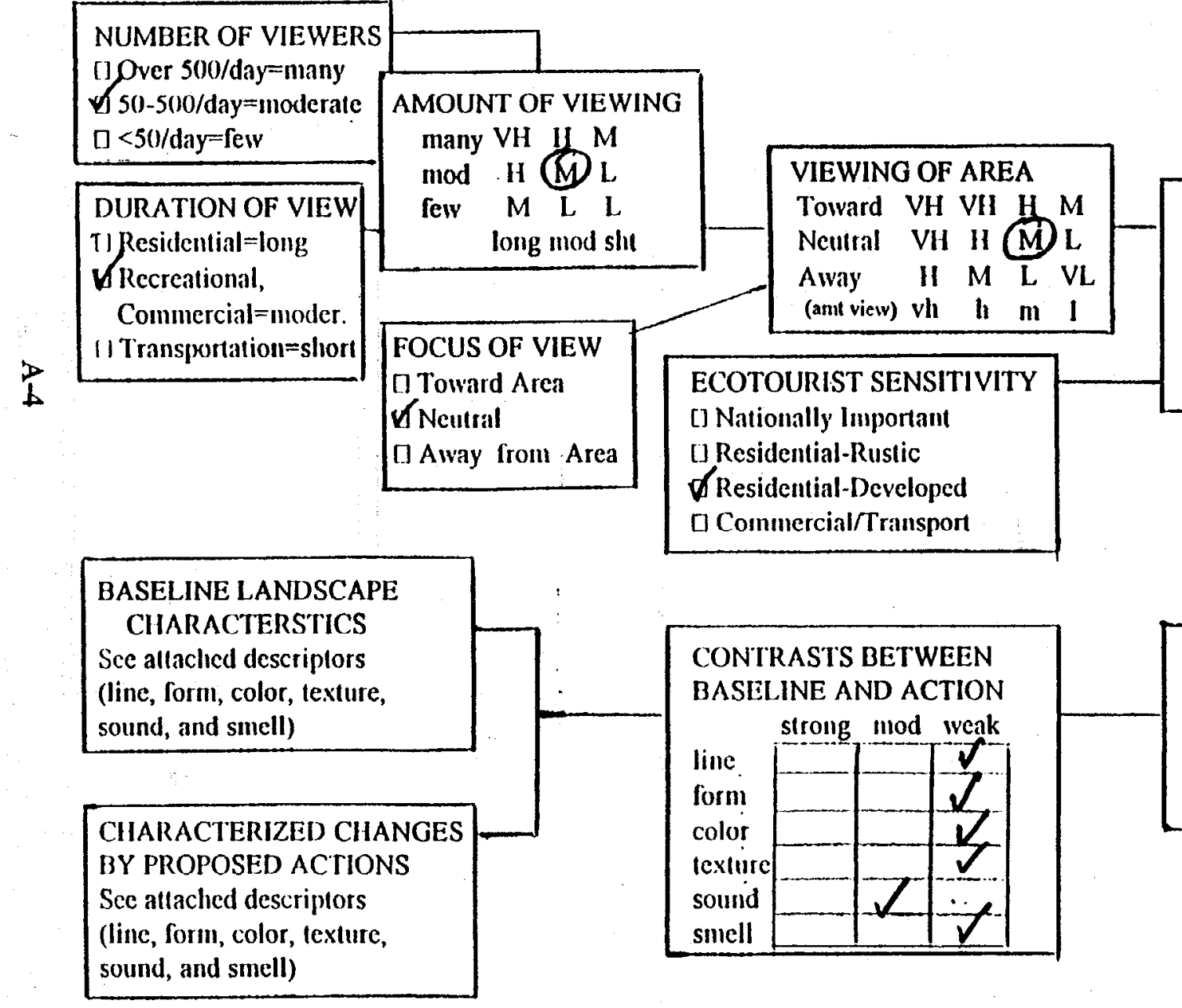

\section{VIEW SENSITIVITY}

Nat'l VH VII II H M

Rustic VH VH II H $\mathrm{M}$

Devel. H H (M) M L

Comm. M M L L L

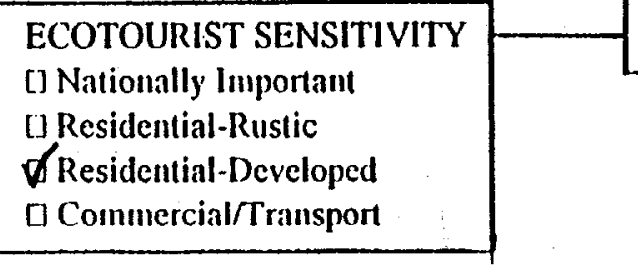

(sensit.) vil ll

\begin{tabular}{|llllll|}
\hline AESTHETIC & IMPACT & & \\
v.strong & VH & VH & H & H & M \\
strong & VH & $H$ & $H$ & $M$ & L \\
medium & $H$ & $H$ & M & L & VL \\
weak & M & M & L & VI & VL \\
(sensitiv.) & vh & h & III & I & vl \\
\hline
\end{tabular}

INCOMPATABILITIES

[ $>3$ (v. strong)

[] 1-3 (sirong)

10 strong, any med (med)

$\square$ no strong or med (weak)

Figure A.3

11




\section{Rio Dulce EIS Aesthetic Impact Analysis}

Key Area Assessment Worksheet

Eolfete
Area Name Corridor

Simpson Action $\sqrt{\text {; Alternative Action }}$

NUMBIER OF VIEWERS

IIOver $500 /$ day $=$ many

$\checkmark 50-50(0) /$ day $=$ moderate

[1 $<50 /$ day $=$ few

DURATION OF VIEW

[] Residential=long

$\checkmark$ Recreational,

Commercial=moder.

察

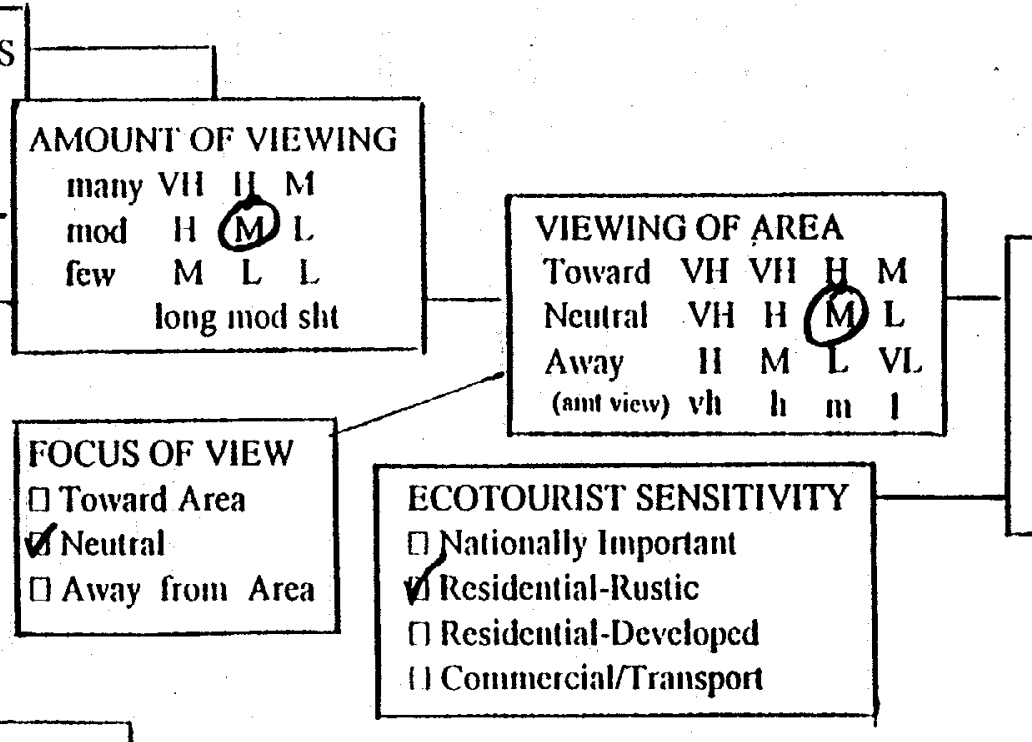

VIEW SENSITIVITY

Nat'l VH VH II H $\mathrm{M}$

Rustic VH VH (H) H $\mathrm{M}$

Devel. II II M M L

Comm. M M L L L

1) Transportalion=short

(sensit.) vh $h \mathbf{m} /$ AESTHETIC IMPACT

0 Toward Area

$\checkmark$ Neutral

ECOTOURIST SENSITIVITY

onally lmportan

П Residential-Developed

HCommercial/Transpor

BASELINE LANDSCAPE

CHARACTERSTICS

Sce allaclied descriptors

(line, form, color, lexture,

sound, and smell)

\section{CHARACTERIZED CHANGES}

BY PROPOSED ACTIONS

See altaclied descriptors

(line, form, color, lexture,

sound, and smell)

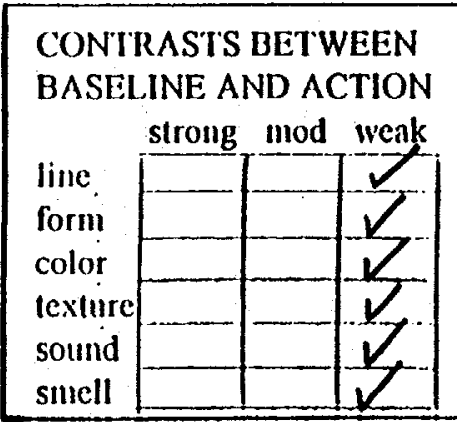

Figure A.4 


\section{Rio Dulce EIS Aesthetic Impact Analysis}

\section{Key Area Assessment Worksheet}

Area NameChocon-Machacas; Existing Condition $V$; Master Plan $\underline{V}$; Simpson Action $\mathscr{S}$; Alternative Action

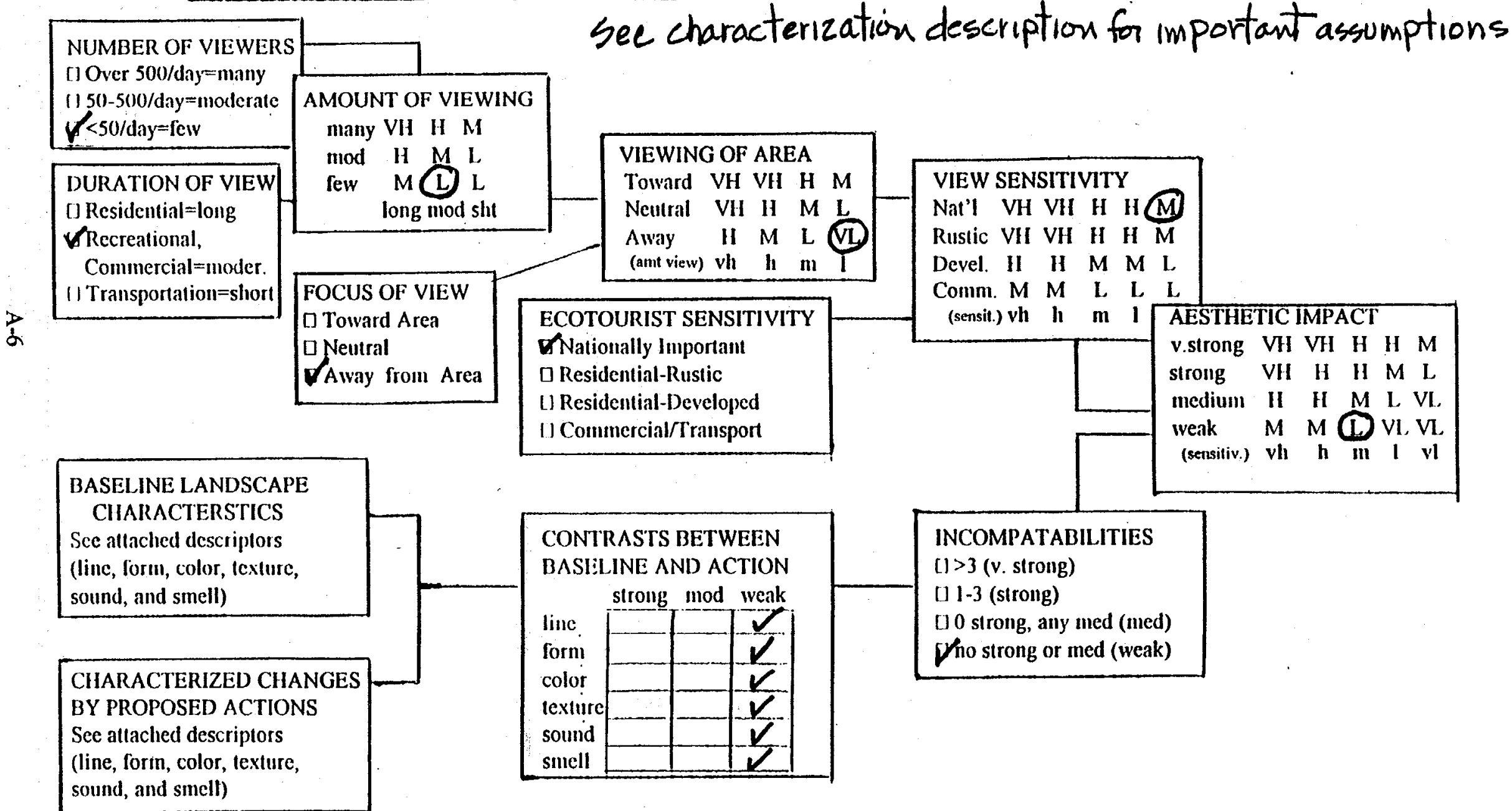

Figure A.5

1

1

1

I

1

1

1

1 


\section{Rio Dulce EIS Aesthetic Impact Analysis}

Key Area Assessment Worksheet

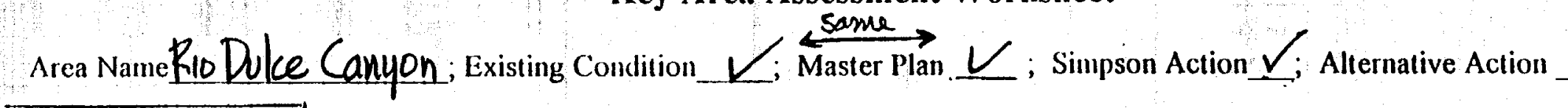

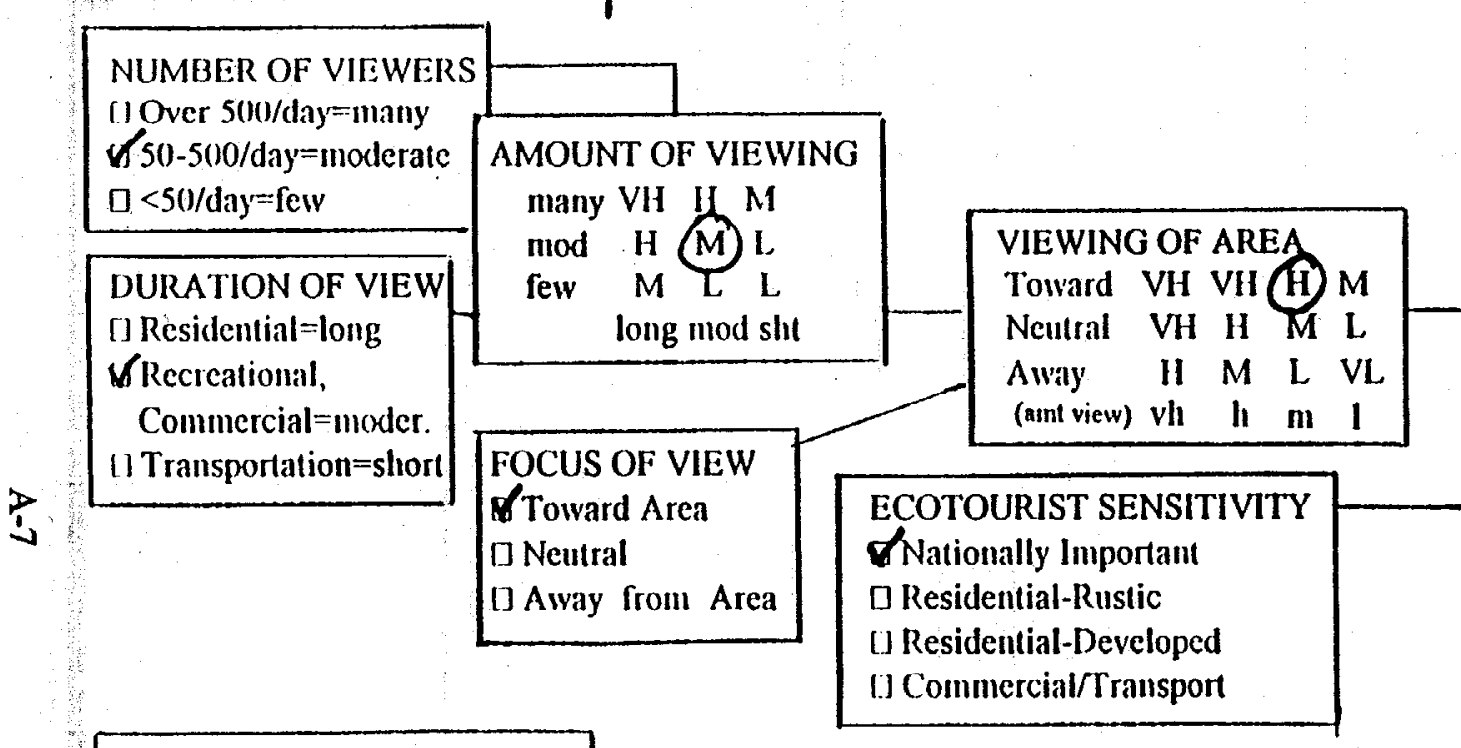

BASELINE LANDSCAPE CHARACTERSTICS See allached descriptors (line, form, color, lexture, sound, and smell)

\section{CHARACTERIZED CHANGES} BY PROPOSED ACTIONS

Sec attached descriptors (line, form, color, texture, sound, and smell)

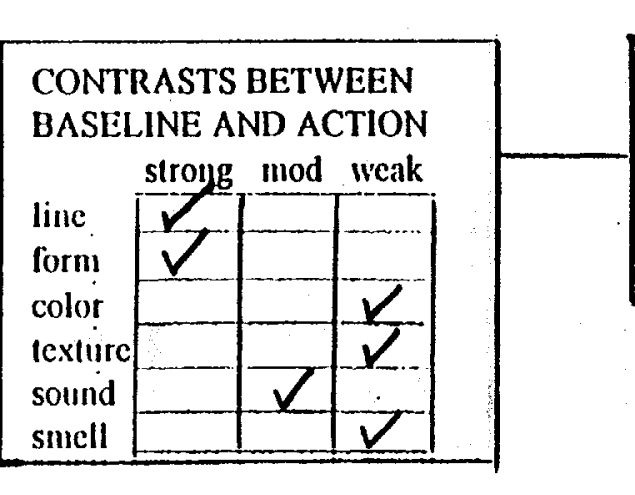

\section{VIEW SENSITIVITY \\ Nat'l VH $\mathrm{VH}$ H $\mathrm{H} \mathrm{M}$ \\ Rustic VII VII II H $M$ \\ Devel. II H M M L}

Comm. M M L L L

(sensit) vlı h $m /$ AESTHETIC IMPACT

v.strong $\mathrm{VH}$ VH H $\mathrm{H} M$ strong $\mathrm{VH}$ H $\mathrm{H} \mathrm{M} \mathrm{L}$ medium $H \quad H \quad M L V L$ weak $M \quad M \quad L$ VL, VL (sersitiv.) vh h $\mathrm{ll}$ । vl

Figure A.6 


\section{Rio Dulce EIS Aesthetic Impact Analysis Key Area Assessment Worksheet}

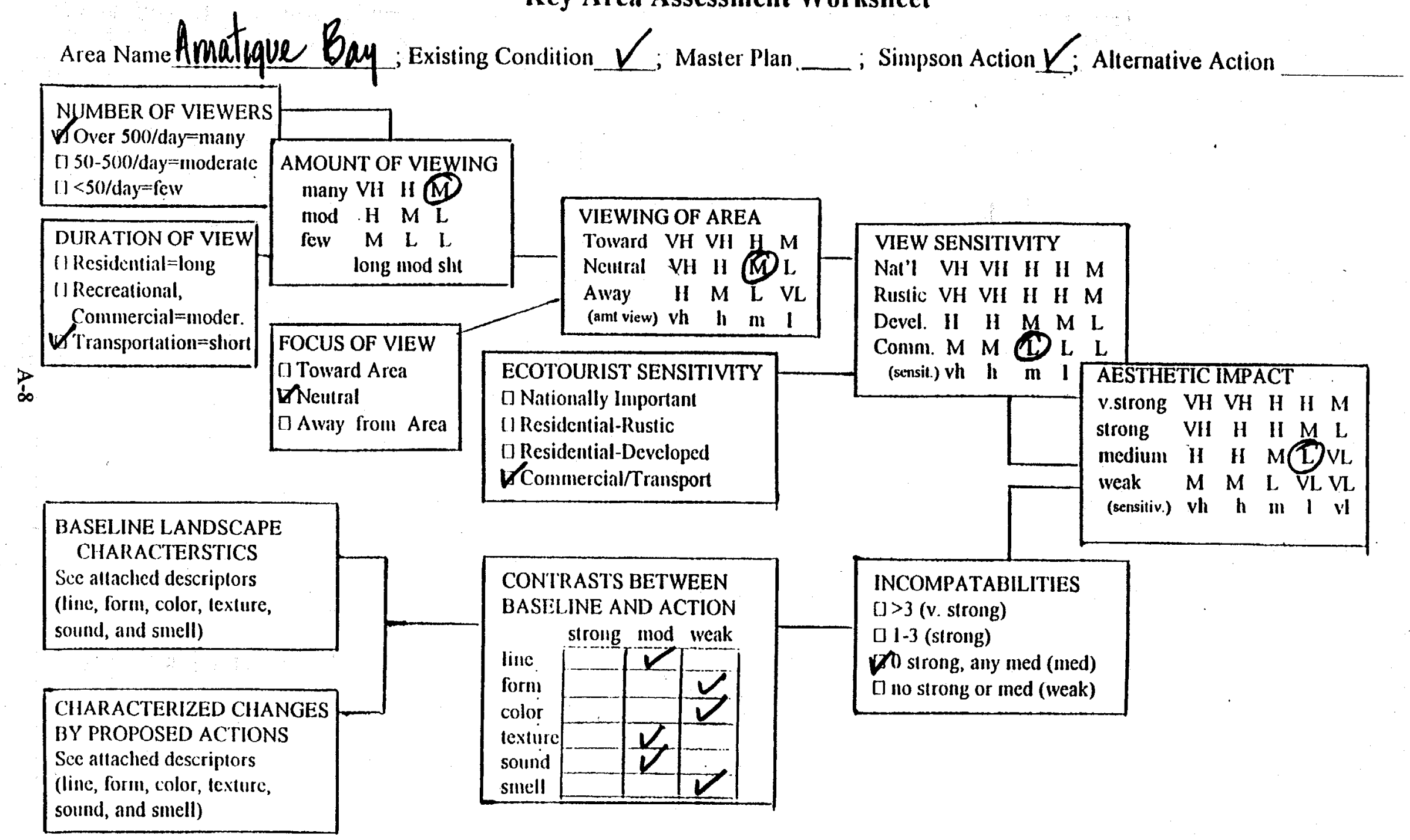

Figure A.7 
Area NamePlantation ¿Roack; Existing Condition $\nu$; Master Plan.

\section{Rio Dulce EIS Aesthetic Impact Analysis}

Key Area Assessment Worksheet

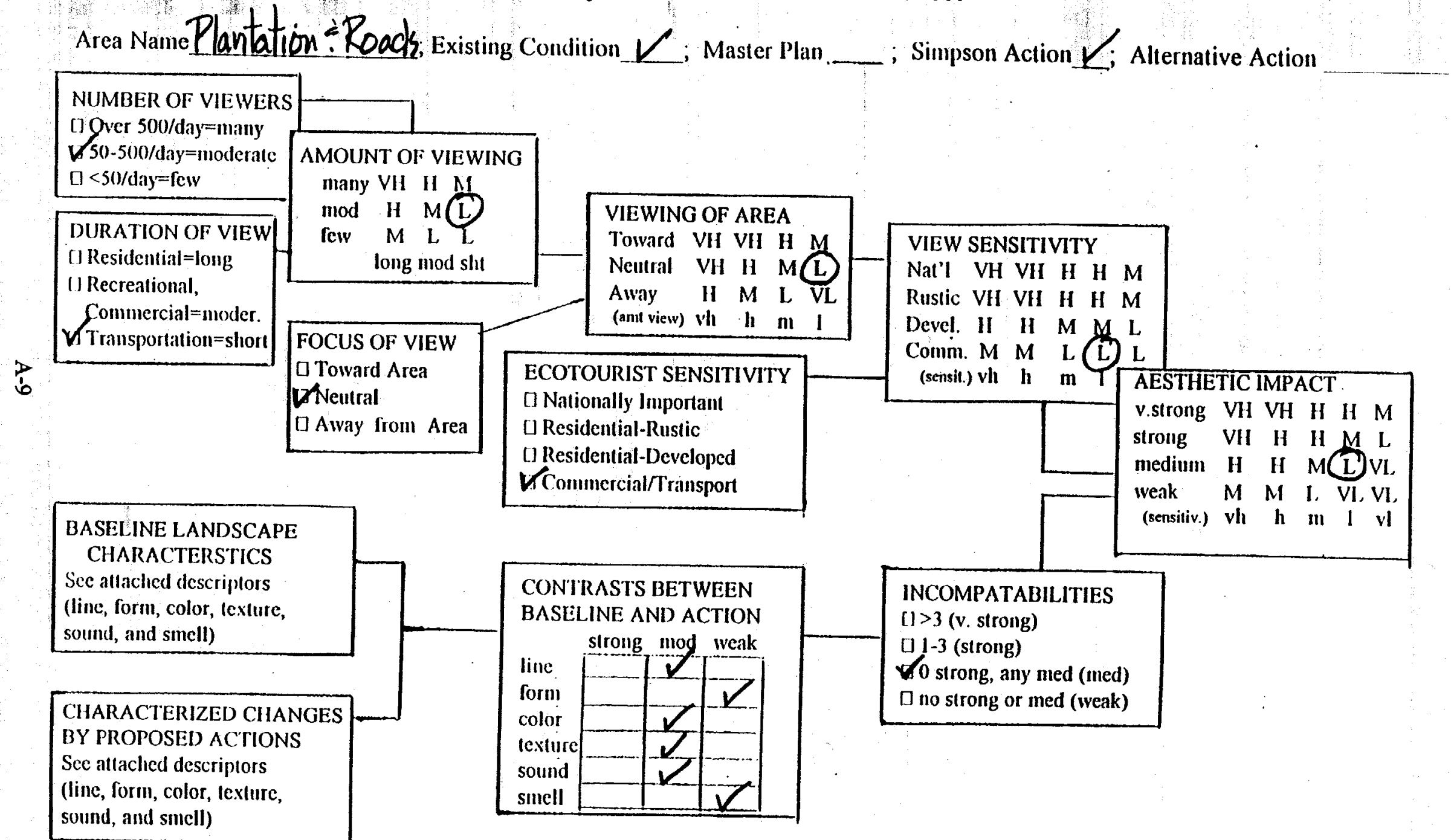




\section{Rio Dulce EIS Aesthetic Impact Analysis \\ Key Area Assessment Worksheet}

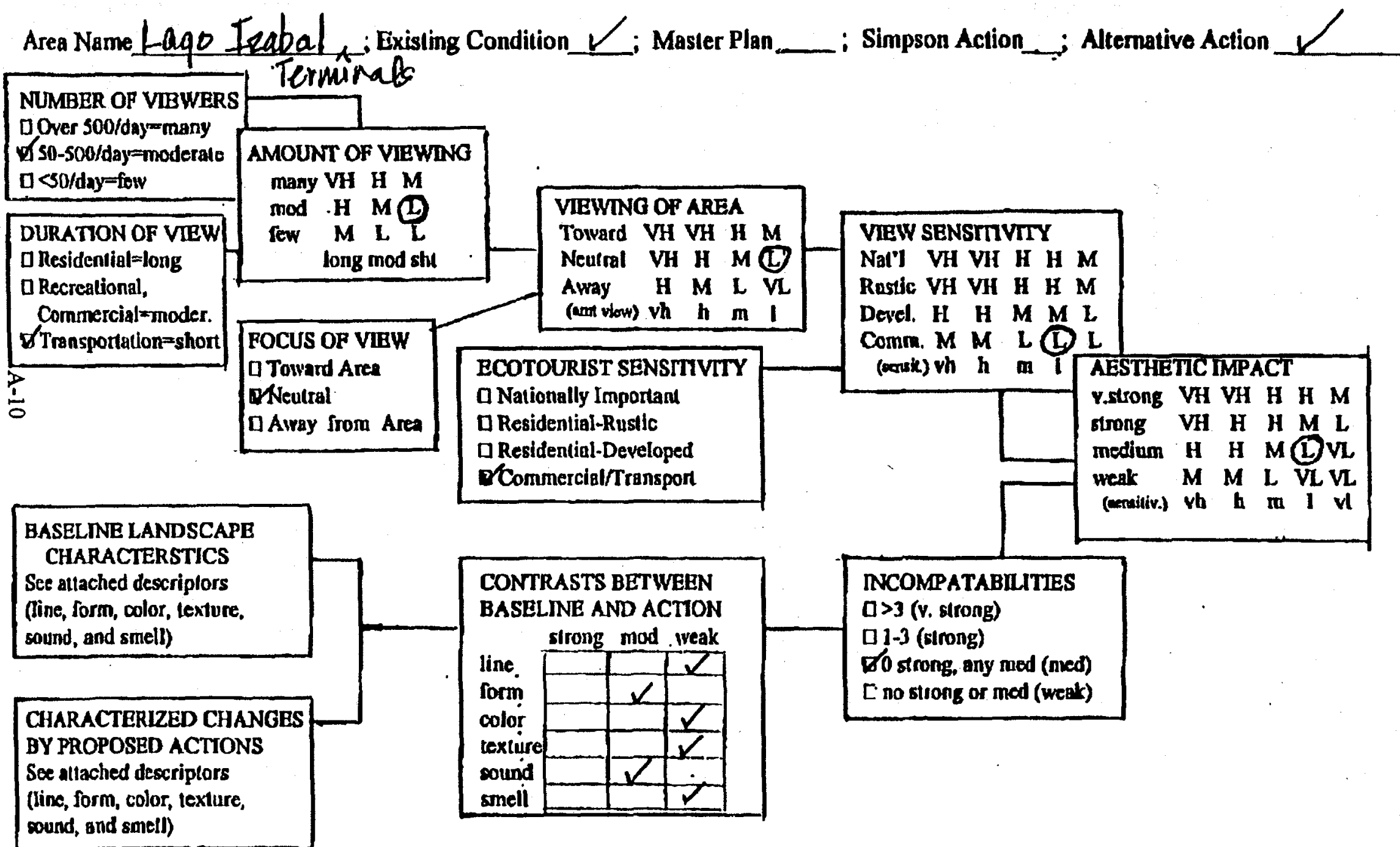

Figure A.9 
This methodology provides a helpful approach on aesthetic evaluations from two points. The first is that the contrasting elements and most critical sensitivities are easily identified and help in the identification of ameliorating alternatives. The second is that the aesthetic evaluation process reveals the logic of the process for all to consider. Aesthetics cannot be made totally transparent in logic which makes the presentation of the employed methodology all that more important.

For each key aesthetic area, the existing aesthetic situation is defined. Where appropriate, the Rio Dulce Master Plan is interpreted in terms which will allow comparisons with existing and proposed actions.

Various aesthetic components are considered generally in relative nonparametric terms. Results are approximations rather than exact definitions. Steps are shown in interpreting the Master Plan. Calculations for each site include:

Number of viewers $\times$ Duration of views $=$ Amount of viewing

Amount of viewing $\times$ Focus of views $=$ Viewing of project

Form $_{(\mathrm{a})}+\operatorname{Line}_{(\mathrm{a})}+$ Color $_{(\mathrm{a})}+$ Texture $_{(\mathrm{a})}+$ Sound $_{(\mathrm{a})}+\operatorname{Smell}_{(\mathrm{a})}=$

Characteristic aesthetic $c_{(a)}$

Characteristic Aesthetic $_{(a)}-$ Aesthetic $_{\text {Changes }}\left(\right.$ Ancompatibility $_{(a-b)}$

Viewer Sensitivity $\times$ Viewing of project $=$ View Sensitivity*

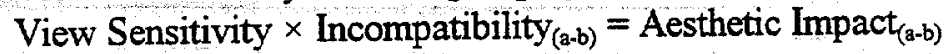

*View sensitivity can be modified to reflect specific stakeholder situations if needed. This was not done in this assessment due to insufficient data.

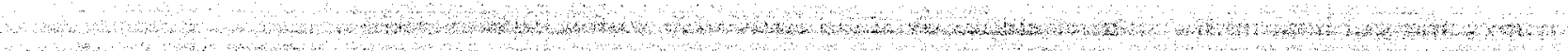

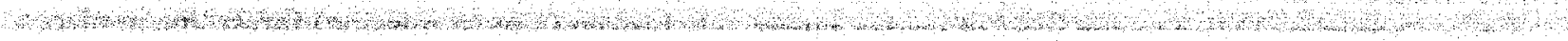

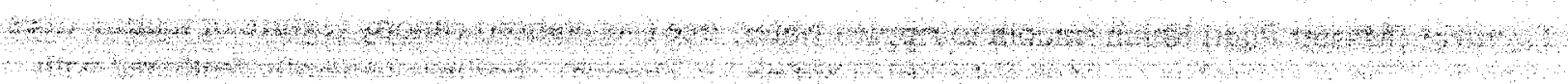




\section{A.1 INTENSIVE USE AREA AND LOAD TERMINAL NEAR RIO DULCE BRIDGE}

\section{A.1.1 Existing}

Continuous forest profile along water's edge east of bridge, highly broken west of bridge

Limited low profile hotels, condos, restaurants

Up to medium sized utility and pleasure craft

Intensive water recreation

Raw sewage emissions

Small outboard motor sounds most of day

Light to medium commercial enterprises

Broken continuity in aquatic shoreline vegetation

Piers, ramps, and occasional concrete structures and bright signs at water's edge

Eating away chunks of forest, some protection involved

Light to medium commercial traffic supporting any activity

6-7 marinas
Master Plan (assumptions/interpretation)

Continuous forest profile along water's edge, ameliorate existing exceptions

No constant loud banging noises

Numerous commercial but low profile hotels, etc. of native architecture

Larger (40-60') pleasure craft and somewhat smaller utility craft permissible

Intensive water recreation

Septic systems and waste treatment necessary

Small-medium engines, some diesel, any time

Light to medium commercial enterprises (no heavy)

Continuous and maintained aquatic shoreline vegetation

Minimum visual impact construction such as wooden piers and very few ramps and concrete retaining walls; signs must blend with landscape

Protect any significant chunks of existing forest cover, forest reclamation activities

Light to medium commercial traffic in support of tourism

Perhaps up to 10 marinas

\section{A.1.2 Characterization of Above}

Line: [Master Plan] Continuous but wavy forest canopy line along water's edge; dominant straight horizontal water broken only by small boats and islands/peninsulas; small striking vertical lines of tree trunks and sail boat masts, sharper angles by small structures within forest context

[Existing Exceptions] Next to and west of bridge extensively broken (almost missing) forest line in places, very broken shoreline by piers, boats, docks, and clearings.

Form: [Master Plan] General rounded forms of tree tops, forest islands; limited middle ground views containing hills of only slightly rounded form (e.g., long and low); land use blocks on hillsides slightly more angular, many roof forms somewhat rounded (sloped thatched rooves with rounded corners)

[Existing Exceptions] Block forms (buildings) plainly at water's edge west of bridge, channelized subdivision effect considerably to the east

Color: [Master Plan] Dark greens (vegetation), browns (houses, tree trunks, some boats), blue-greys (water), and white (boats and some structures)

[Existing Exceptions] Brightly colored (orange and yellow) and lighted gasoline sign near proposed terminal, a few residential structures of white color

Texture: [Master Plan] Much smooth to rippled water, tree (vegetation) canopy texture of mature trees viewed at $100 \mathrm{~m}$ to $3 / 4 \mathrm{~km}$ (ruffled and mottled but no big clumps), rooflines generally feathered with thatching

[Existing Exceptions] Very smooth walls of structures west of bridge

Sound: [Master Plan/Existing] Silence to 5:45 A.M.; small outboards, monkey howls, rooster and bird calls, and infrequent rumblings of larger diesel inboards from 5:45 A.M. to 10 P.M., constantly loud activity 
of these after 7:30 A.M. Truck traffic sounds from Rio Dulce bridge (not constant) starting about 6:30-7:00 A.M. till dark. Monkey howls stop by 6:00 A.M. Perhaps 2-3 sharp loud banging sounds (wide variety) per day usually after 9 A.M. and before 6 P.M. Occasional sound of people talking through the day. Loud music and boisterous voices after dark and up to midnight 1 or 2 nights a week.

Smell: Mostly river water without any hints of pollution or dead fish. Occasional 2-cycle engine exhausts and from time to time the smell of food cooking. Fuel smells only close to gas stations and main commercial areas.

\section{A.1.3 Example Components}

The loading terminal as viewed from the main Rio Dulce channel and lagoon area would be considered one of the most important aesthetic factors of the proposed action in the Intensive Use Area (Figure A.10). It would present a permanent impact in a high viewing area. Visual contrast would be expected to be generated from the forest canopy notch and the large barge size which would be out of scale to other features. No tugboat is depicted but it would be only slightly larger than the larger pleasure craft in the area. Sounds from loading activity are also of concern. The view is not drawn exactly to scale but does generally portray the visual issues of concern.

The combined effect of a conspicuous notch in the forest canopy with no forest backdrop (just sky) and the focus generated by sounds of loading (and the nearby brightly colored gas station sign) and a moving loading crane make for strong aesthetic impact. During each working day, a $60 \mathrm{~m}$ long barge would be temporarily moored nearby. Empty barges would appear approximately $3 \mathrm{~m}$ tall. A broadside view of an empty barge $(3 \mathrm{~m} \times 60 \mathrm{~m}$ ) would blend with nothing in the landscape or scene and thus would generate significant temporary undesirable contrast during its presence. Partially filled barges for transport down river would be approximately $1.5 \mathrm{~m}$ tall. This would considerably reduce its negative visual effect.

\section{A.1.4 Contrasts Projected from Proposed Action}

Line: Artificial conspicuous notch generated in tree line (MP=strong, $E=$ =medium) which is first east of bridge and in main intensive use area, conspicuous loading boom in notch ( $\mathrm{MP}=$ medium, $E=$ medium), long $(60 \mathrm{~m})$ barges bringing additional horizontal lines not in alignment with shoreline (bottom and top of barge) and additional vertical lines on side of barge break natural shoreline view significantly $(\mathrm{MP}=$-medium, $E=$ medium).

Form: Barge form is out of scale to man-made influences with long low rectangle (MP=strong, $E=s t r o n g$ ). Color: Large notch in tree line amplified by light background of sky surrounded by darkness and greenery of forest trees. Dark colored barges offer no significant contrast but white of freshly debarked wood in loaded barges contrasts other colors near water ( $\mathrm{MP}=$ medium, $\mathrm{E}=$ weak).

Texture: Loaded logs offer only contrasting texture in scene (MP=weak, $E=$ =weak)

Sound: Tug engine sounds at different frequency but not loudness (MP=weak, $E=$ =weak); logs dropping in barge very noisy, especially when barge empty (MP=strong, $\mathrm{E}=$-medium); arriving and departing 10-ton trucks add to noise levels (MP=moderate, $E=$ weak)

Smell: Some smell of tug diesel, truck exhausts, and fresh cut wood (MP=weak, $E=$ weak). 
Before

Continuous Tree Canopy

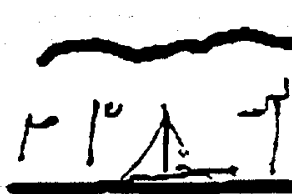

After

Bright sign

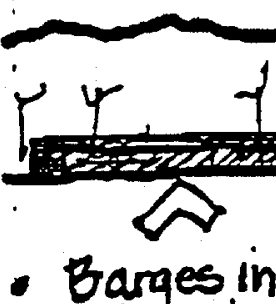

- Barges in

Vicinity

Partof Time
- Notch in Tree

Canopy

- Visible Crane

- Norse from

Loading Activity

Figure A.10

A-14 


\section{A.1.5 Conclusion on Number of Incompatible Landscape Contrasts (Intensive Use Area and}

Terminal Near Rio Dulce Bridge)

\begin{tabular}{lll} 
Landscape & & \\
\hline Component & Existing Conditions & Master Plan \\
Line & Medium & Strong \\
\hline Form & Strong & Strong \\
Color & Weak & Medium \\
Texture & Weak & Weak \\
Sound & Medium & Strong \\
Smell & Weak & Weak
\end{tabular}

\section{A.2 PLANTATIONS AND ADJOINING ROADS}

\section{A.2.1 Existing Condition (before or without plantations)}

Mixed tracts of highly disturbed native forest, grazing land, agricultural land, and local community developments

Open views of landscape mixed with closed views by weedy vegetation Landscape vegetation of mixed sizes and species

Occasional bare soil from poor land management, some excellent green pasture

Paved roads of moderate traffic and suitable for $70 \mathrm{~km} / \mathrm{hr}$ speeds; unpaved roads of low traffic and speeds below $30 \mathrm{~km} / \mathrm{hr}$

\section{A.2.2 Characterization of Above}

Line: Only straight lines are of road way (and painted lines), boles of occasional tall trees, and any housing. Otherwise curved horizons, foot paths, and vegetation outlines.

Form: Irregular shaped blocks of cleared land and native forest with some curved and some straight edges. Rounded tree and bush shapes. Most habitations angular to rounded corners. Horizon has gentle rounded forms with frequent rectangles

Color: Mostly green with a few browns except on paved roads where grey-black. Pastures lighter yellowgreen compared to darker bluer-green of most native vegetation.

Texture: Almost all rough and abrasive because of mostly foreground viewing. Smoother texture of pastures and background of broader views. Recently cleared land is usually rough.

Sound: Few sounds except along roadways. Road traffic is predominantly small vehicle and pedestrian except on paved roads where commercial trucks pass at a rate of a few/hour all day.

Smell: Quite varied depending on location and land use. Mostly forest, vegetation, and earthy smells. Occasional smoke and vehicle exhaust. Sometimes livestock odors.

\section{A.2.3 Example Components}

The introduction of short-rotation gmelina plantations slightly changes the character of what is viewed in both positive and negative ways. The comparison of the positive and negative effects yields an overall acceptable change. Figure A.11 characterizes a typical landscape along a road. The road could be gravel 
Before

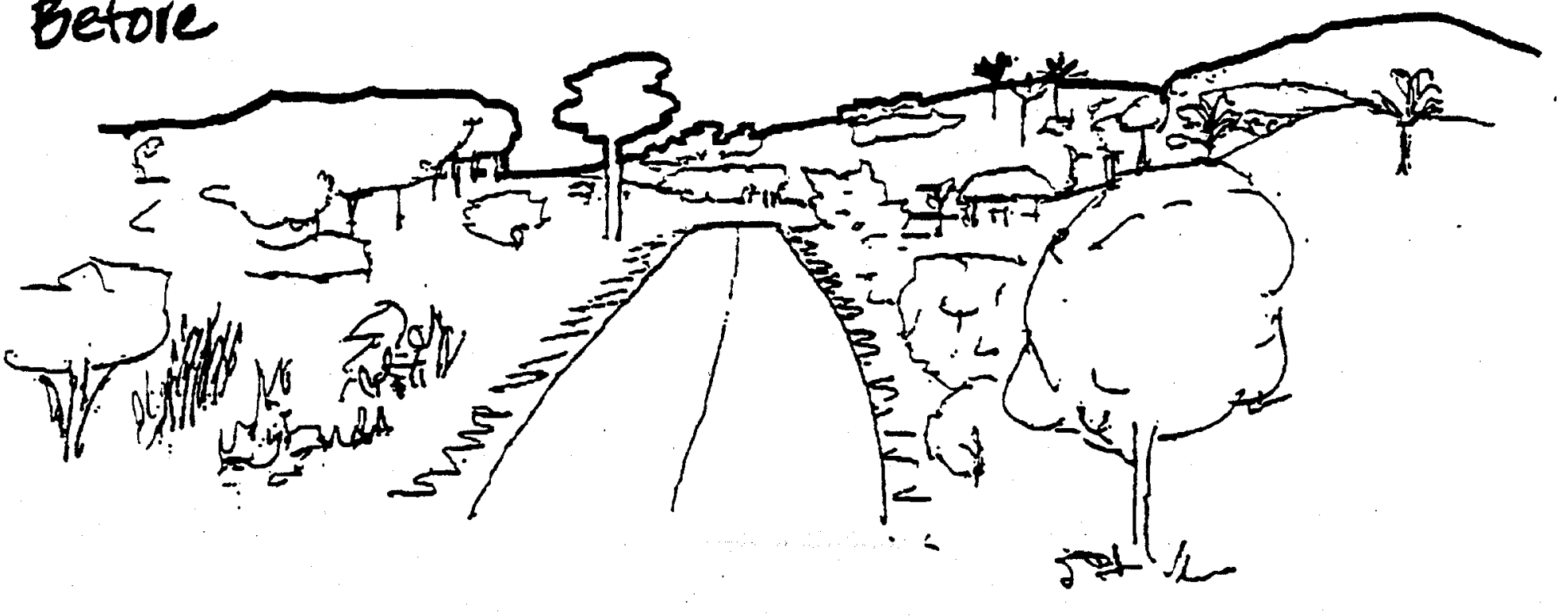

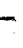

After

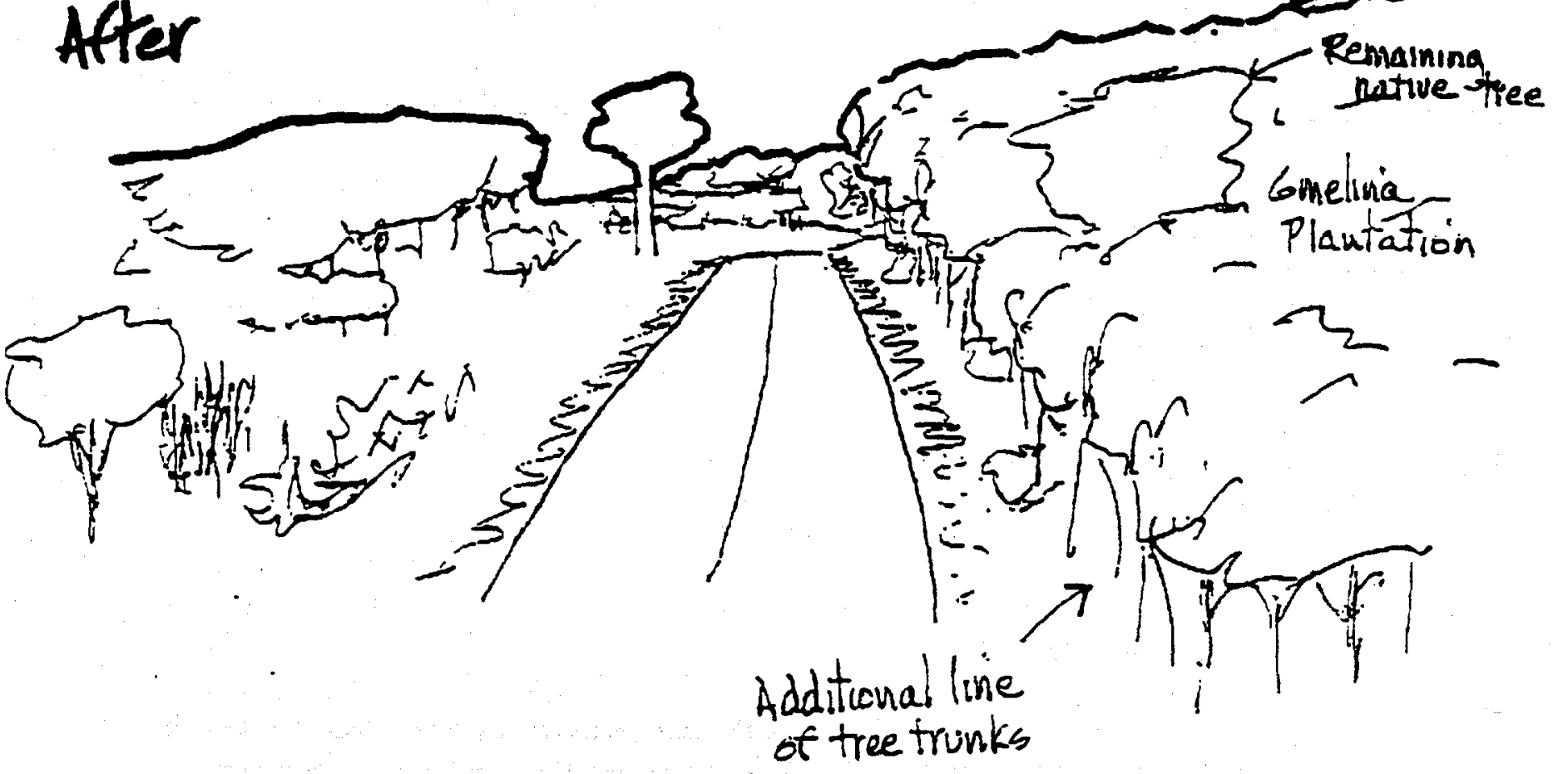

Figure A.11

A-16 
although a paved road is sketched because of the stronger viewing implications. A hypothetical plantation tract is imposed on the right of the road in the "After" sketch. Part of the view of the landscape is blocked by the plantation. However, a more forested experience is presented and the landscape (midground and background) comes back into view down the road. As long as the view is not blocked for many kilometers, the visual effects are quite acceptable. Neither existing traffic or the additional traffic imposed by log trucks is pictured. The pastoral experience of the sketched conditions would be altered by traffic, especially if the trucks contribute to traffic congestion.

The line of the tree trunks in rough rows as imposed by the plantations is rated as a medium visual impact as compared to existing conditions. The color of gmelina (not portrayed in the black-and-white sketches) is a lighter yellow-green compared to the existing landscape but this contrast is not strong. Viewed from a distance (not shown), gmelina plantations appear slightly different in canopy texture from most native vegetation because of gmelina's smoother, more even canopy (a finer texture). In most cases this contrast is acceptable since it is forest cover and not cultivated land.

The visual connection of the plantations will be different at harvest and plantings but the effect will last about one year out of about six. Harvested plantations do not convey the magnitude in visual negativity of native forest harvesting because much less slash is left behind as "clutter and waste." But a brown colored tract will be present for a few months.

\section{A.2.4 Contrasts Projected from Proposed Action (more gravel roads somewhat improved;} monocultures of gmelina on short-rotation)

Line: Many straight lines of boles of gmelina over 1.5 years of age. This is amplified by trees occurring in rows. Pronounced but infrequently visible straight lines of plantation edges unusual in landscape. These edge lines pronounced during harvest/establishment. Additional service roads will add more lines to landscape but this will generally be unnoticed by travelers. [medium]

Form: The major form change will be the canopy of the gmelina which will be rounded at the margins but long and elevated. Form of cleared land during establishment same as surroundings, only larger. [weak] Color: gmelina plantations offer a mildly lighter green as a forest cover but this is still somewhat darker green than the grazing land use being displaced. Much contrast of brown on land at harvest time $(.5$ years out of 6) [medium]

Texture: The plantations are homogeneous and finer in texture than either grazing land (which is broken by clumps of native vegetation) or native forests (all-aged stands). At close view, the understory offers a very contrasting texture of leaf-littered shady ground and many stems of young trees. Big texture change during harvest/establishment. [medium]

Sound: Mostly added 10 ton trucks on roads both forest access and paved and both significant. [medium] Smell: Only added smells are from added truck exhaust and land burning (provided labor camps are kept sanitary).[weak]

\section{A.2.5 Conclusion on Number of Incompatible Landscape Contrasts}

$\begin{array}{lc}\text { Landscape Component } & \begin{array}{c}\text { Existing Conditions } \\ \text { medium }\end{array} \\ \text { Line } & \text { weak } \\ \text { Form } & \text { medium } \\ \text { Color } & \text { medium } \\ \text { Texture } & \text { medium } \\ \text { Sound } & \text { weak } \\ \text { Smell } & \end{array}$




\section{A.3 GOLFETTE CORRIDOR}

\section{A.3.1 Existing}

Broad, long lake with occasionally moderate boat traffic

Boat traffic of small to medium sized pleasure and working craft

Infrequent large tourist craft

Noises not an issue, usually quiet

South side source of moderate viewing from special use zone

Part of north side a wilderness-type reservation with wildlife viewing and only small boats

Very few remnant navigational aids

Wildlife sounds can be important on north side

\section{Master Plan (assumptions/interpretation)}

Broad, long lake with increased boat traffic mostly in support of tourism and small commercial

Few limits on boat size but mostly tourist-related

Periodic large tourist craft

Boat noises not an issue except near Primitive Area

South side viewing compatible with rustic tourism

No non-tourist commercial boats within $3 / 4 \mathrm{~km}$ of

Primitive area, only small boats inside this distance

Navigational aids permitted but no flashing lights

Increased wildlife sounds and manatee viewing

\section{A.3.2 Characterization of Above}

Line: From shoreline, long dominant horizontal line of lake surface and opposite shore line horizon. No noticeable notches in shoreline horizon and little variation caused by boat traffic. From water, small houses, huts, piers, and boats form limited but agreeable line contrast.

Form: Large rolling mountains in background with rectangular patches of clearing visible in clear weather. Color: Mostly middleground which slightly dulls the greens, browns, and blues of vegetated shoreline and lake surface

Texture: Water extremely smooth in calm weather, somewhat ruff otherwise. Boat wakes not an issue. Vegetation mostly smooth and fluffy looking at a distance, somewhat ruffer texture within $1 / 2 \mathrm{~km}$.

Sounds: Usually muffled by distance and frequent boat sounds

Smell: Nothing but unpolluted water, sometimes sea water smell.

\section{A.3.3 Example Components}

As can be seen in Figure A.12, the visual and aesthetic contrast offered by barging in the Golfete would be weak. Long horizontal lines of the opposing shoreline, the presence of other boats, and the long horizontal lines of barges would be compatible. Barges would be moving perhaps $7 \mathrm{~km} / \mathrm{hr}$ creating minimum wakes. These passes would occur 1 to 2 times per day which does not generate a traffic issue, even with the slow pace of the barges. Few logs should be visible protruding above the gunnels of the barge. This would minimize visual effects. The sketch does not depict any navigational aids.

The view from the Chocon Machacas Biotope of barge movement up and down the Rio Dulce would offer even less contrast as expressed above because of greater distance between the viewer and the barges. Barges or boats for servicing plantations in the tributaries of the Rio Dulce in the Chocon Machacas

Biotope were not sketched because the Simpson proposed action did not specifically include such activity. 


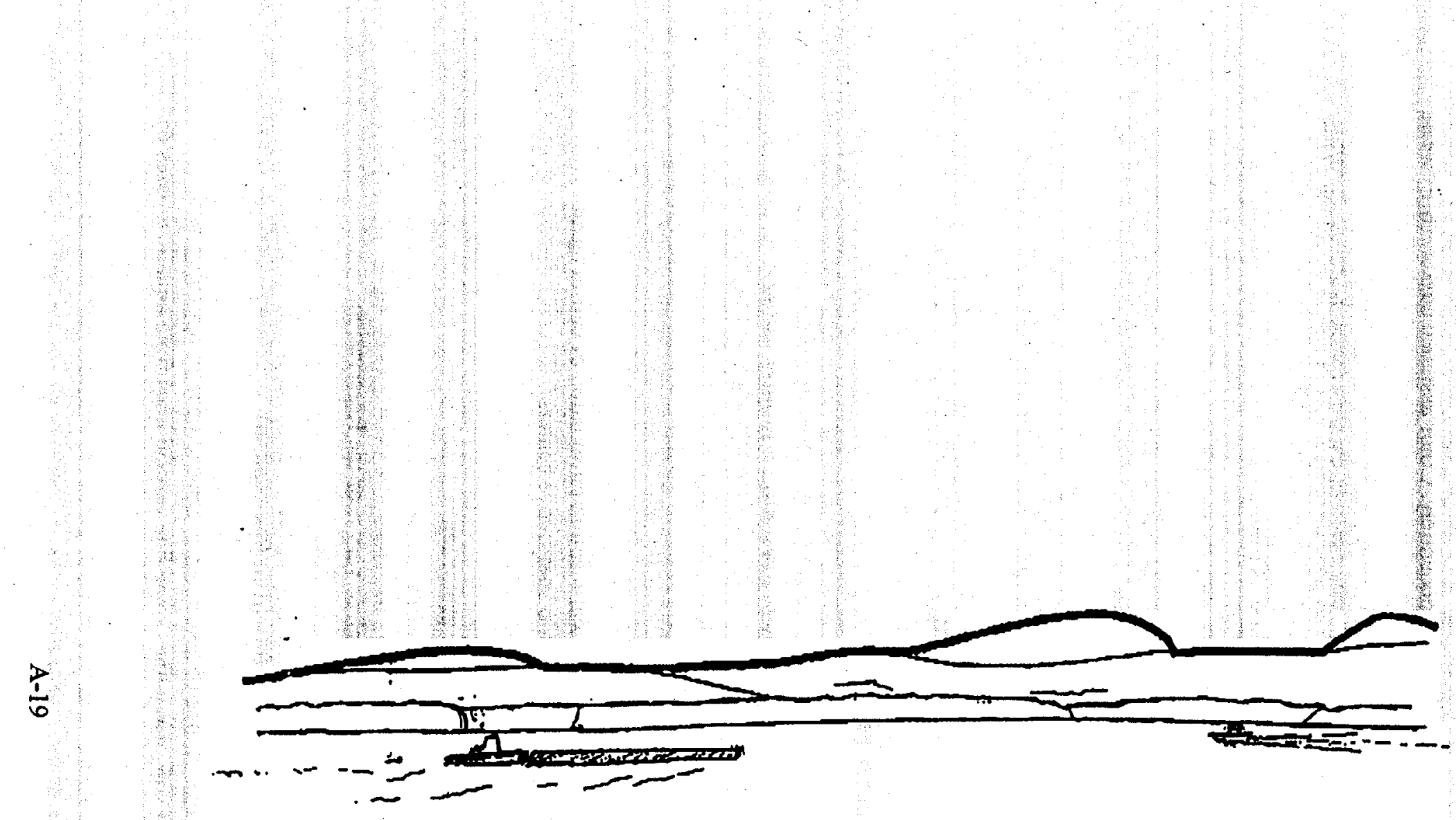

Figure A.12 


\section{A.3.4 Contrast Projected from Proposed Action}

Line: None sufficiently detectable ( $\mathrm{MP}=$ weak, $E=$ weak)

Form: Long low barges at a distance of more than $1 / 2-3 / 4 \mathrm{~km}$ will match long dominant horizontal line of lake surface and vertical lines of barges not noticeable (MP=weak, $\mathrm{E}=$ weak)

Color: If barges are darker colors (brown, grey, dark green) the contrast will be minimal. If white, yellow, orange, or other bright warm colors, barges would contrast moderately. Color assumed darker. (MP=weak, $\mathrm{E}=$ weak)

Texture: None sufficiently detectable in contrast, limited wake effect (MP=weak, $E=$ weak)

Sounds: Deep sounds of tug may contrast other boats in existing situation but loudness is the same. With added traffic of Master Plan, the difference will not quite be lost in the traffic (MP=weak, $E=$ medium)

Smell: None sufficiently detectable in contrast (MP=weak, $E=$ weak)

\section{A.3.5 Conclusion on Number of Incompatible Landscape Contrasts}

$\begin{array}{lcc}\text { Landscape } & & \\ \text { Component } & \text { Existing Conditions } & \text { Master Plan } \\ \text { Line } & \text { weak } & \text { weak } \\ \text { Form } & \text { weak } & \text { weak } \\ \text { Color } & \text { weak } & \text { weak } \\ \text { Texture } & \text { weak } & \text { weak } \\ \text { Sound } & \text { medium } & \text { weak } \\ \text { Smell } & \text { weak } & \text { weak }\end{array}$

A.4 CHOCON MACHACAS BIOTOPE AND RIVERS (Proposed Transport of 250,000 tons/yr of wood by Commercial Barge (also access to gmelina plantations)_Primitive Zone)

A.4.1 Existing (Master Plan assumed the same as existing conditions-i.e., Preservation/wilderness/ visitor information)

Undeveloped, natural shoreline fully wooded or in process of restoration

No dredging anywhere; any bottom or shoreline scouring will result in termination of causal agent

1-3 small docking facilities for small boats only; very rustic interpretive centers

As much quietness as possible; no flashing lights visible on water

No wake rule within $1 / 4 \mathrm{~km}$ of Primitive Zone

Areas designated off limits to motorized craft for manatee protection

Local native traffic in indigenous boats dominant in tributaries

Fishing and crabbing only by locals for household use only (fishing preserve) in Reservation

No transport of commercial chemicals or fertilizers through or very near the Reservation

Commercial traffic at least $3 / 4 \mathrm{~km}$ from primitive docking facilities

\section{A.4.2 Characterization of Above (i.e., view of Golfete from Reservation)}

Line: Continuous highly pronounced horizontal line of lake surface. Special uses on opposing bank (midground/background) form horizon of soft, wavy line. Some fine vertical lines from aquatic grasses on near shoreline 
Form: Major forms are strong narrow horizontal band between water and canopy across water; large rounded mountain in background with some rectangular forms visible partway up slope. All boats of low profile.

Color: All natural colors (brown, blue, green, grey) except for some pleasure craft of bright white color. Texture: Dominated by condition of water surface (varies from smooth to rough) and texture of vegetation canopy on opposite shoreline and mountains (fluffy).

Sound: Occasional boat motors of light to medium size; occasional bird and animal sounds; often sounds of water droplets falling through canopy.

Smell: Clean. No fuel and often no fire smells; wet tropical rainforest smells which include soil, flowers, and greenery. Very little smell from lake water.

\section{A.4.3 Example Components}

The view of barges in El Golfete from the Biotope would offer even less contrast than the previous view because of greater distance between the viewer and the barges.

\section{A.4.4 Contrasts Projected from Proposed Action (assumes no commercial traffic by Simpson on} waterways within Chocon Machacas Reservation)

Line: Barges at such a distance $(1 / 2+\mathrm{km})$ from Reservation to not offer much contrast; length of barge and tug in scale with surroundings; barge wake insignificant [weak]

Form: Empty barge provides $3+\mathrm{m} \times 60 \mathrm{~m}$ profile of rectangle above water but appears small at the distance viewed from the Reservation. Tug blends as just another boat on the water at viewing distance from Reservation. [weak]

Color: Assumes barges are natural neutral color (brown) so no contrast in color from barge itself. Newly debarked logs will be very light but low in barges and should not be a major source of contrast. Lights on barges at night will seem little different from other traffic on water [weak]

Texture: If logs are visible, this will be the only significant source of texture contrast (whether jackstrawed or piled in alignment). This should still be considered weak contrast. [weak]

Sound: Sound of tug will be deeper than most other boats. Also slower moving $(5-6 \mathrm{~km} / \mathrm{hr})$ will keep sound in hearing range longer but distance will muffle sound. Assumes no tug horns and no navigational aids using homs or sounds. [weak]

Smell: No smell contrasts expected [weak]

\section{A.4.5 Conclusion on Number of Incompatible Landscape Contrasts Niew of Golfete barge traffic from Chocon Machacas Manatee Reservation)}

$\begin{array}{lc}\text { Landscape Component } & \text { Existing Conditions and Master Plan } \\ \text { Line } & \text { weak } \\ \text { Form } & \text { weak } \\ \text { Color } & \text { weak } \\ \text { Texture } & \text { weak } \\ \text { Sound } & \text { weak } \\ \text { Smell } & \text { weak }\end{array}$




\section{A.5 RIO DULCE CANYON}

\section{A.5.1 Existing and Master Plan}

Containing a few rustic uses as small native huts, inconspicuous tourist services, forests, low intensity agriculture scattered between cliffs and forests, and much fishing by indigenous population in small boats. Natural scenic beauty of canyon is dominant

Moderate river traffic, especially on weekends, mostly of pleasure craft, small utility boats, and occasional small commercial craft. Some larger tourism craft from time to time but no regular heavy commercial traffic

Clean water, numerous herons, egrets, and sea birds.

No navigational horns or other types of warning devices based on sounds. No visual navigational aids.

\section{A.5.2 Characterization of Above}

Line: wavy lines of crooked shoreline, vertical lines of trees and vines on cliff, occasional inconspicuous vertical and horizontal lines of hut walls.

Form: a dominant component with large rounded rock surfaces of canyon wall, rounded forms of vegetation patches and darker areas under overhanging cliffs and vegetation, rounded canyon tops and walls at bends in river. All structures have slightly rounded roof form of native vegetative material, tree crowns in profile against canyon walls generally quite rounded

Color: natural colors of green (native vegetation), brown (limited shoreline), grey (rock outcrops of cliffs), and blue-grey (river water). Occasional white birds and pleasure craft in high contrast. Often shaded. Texture: all vegetation in near or midground and is rough-to-fluffy (compared to smooth at a distance), rock texture of generally smooth but abrasive texture, water very smooth with current swirls, all housing is rough (native material) texture matching vegetation.

Sound: Quiet except for motorized craft and occasional wildlife sounds. Sometimes breeze sound audible. Smell: One of fresh rainforest and shady, cooler area. No smell from water.

\section{A.5.3 Example Components}

The introduction of barges, tugboats, and navigational aids to this canyon would present some strong aesthetic changes (Figure A.13). The size of the barge would introduce strong horizontal lines, which would be strongly incongruous to the deep canyon conditions. The scale of the barge and tugboat in the sketch is not exact but a close representation. The form of the barge, especially when empty as seen from water level and beside the barge, would present a $3 \mathrm{~m} \times 60 \mathrm{~m}$ wall in a narrow canyon. Viewing traffic would have to pass quite close to the barge and tug thus amplifying the visual experience. If navigational aids were added, the untamed experience of the canyon would be changed. The sign shown as a navigational aid in the sketch may not be accurate as to type, size, and position. It is presented merely to display the presence of a navigational aid on the aesthetic experience in the canyon.

\section{A.5.4 Contrasts Projected from Proposed Action (addition of heavy commercial barge and iug traffic)}

Line: $11 \mathrm{~m} \times 60 \mathrm{~m}$ barge lines will inundate all line components within view because of such long straight lines in a rounded line situation. If vertical lines on barge sides, more contrast added especially on empty barges. Navigational aids will add significant contrast to natural elements. [strong] 


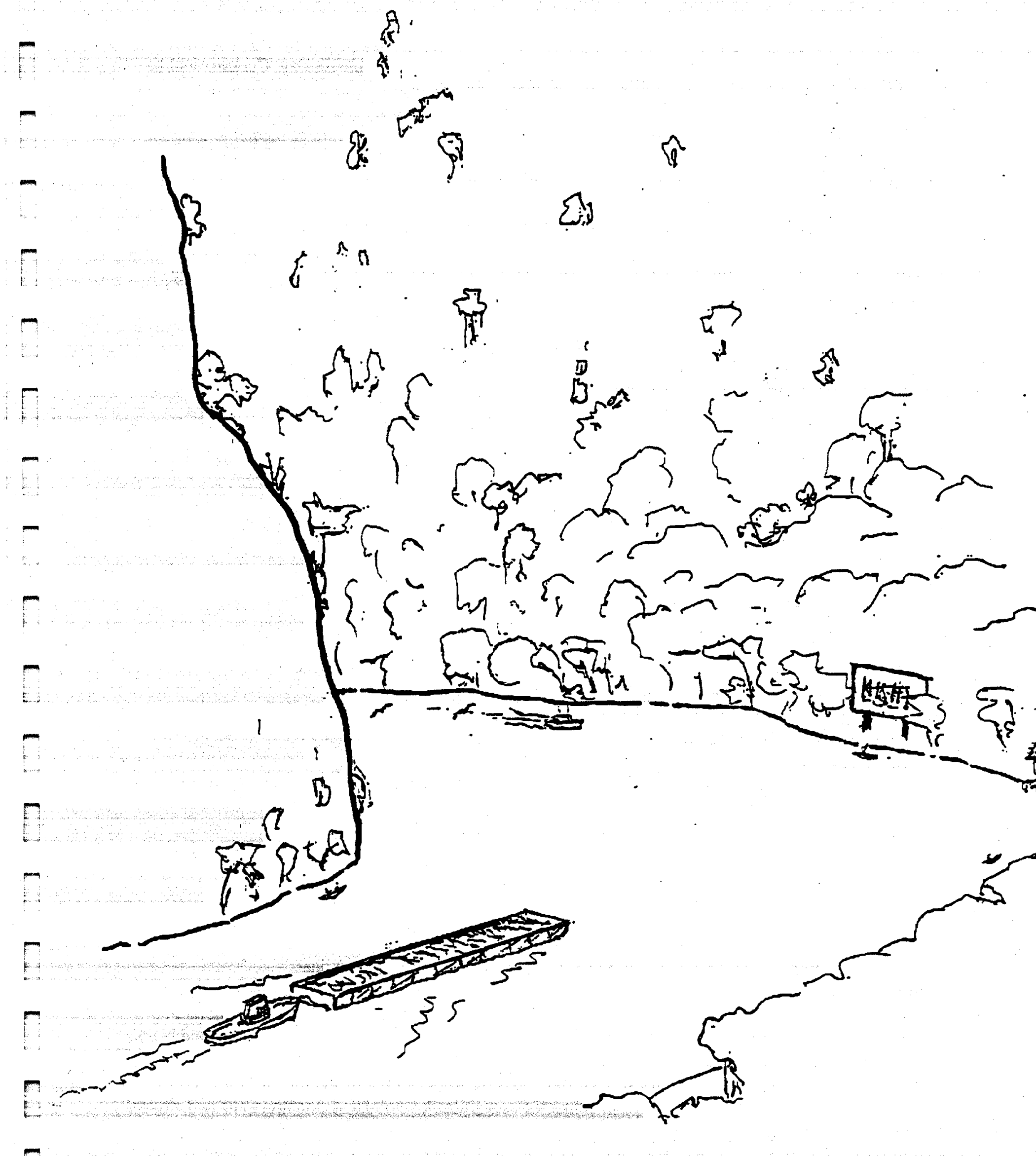

Figure A.13 
Form: Tug will not be too inconsistent with existing boat traffic if only 1-2 passes/day. Contrast will be high if more. Barge is out of scale in size and rectangular shape. Navigational aids will be in strict contrast to surroundings. [strong]

Color: Grey barge would have minimal contrast and any other natural color would be moderate contrast. Color of tug not of much concern. [weak]

Texture: Barge texture assumed to be smooth non-reflective. If so, texture contrast minimal. Other textures of moderate contrast.[weak]

Sound: Tug engine will have moderate to significant contrast with silence and other boating sounds. Any clanging of barge and tug in maneuvering (probably very little) will have great contrast.[medium]

Smell: Tug exhaust will not contrast smell from other larger pleasure craft. Wood will not smell very much. [weak]

\section{A.5.5 Conclusion on Number of Incompatible Landscape Contrasts}

$\begin{array}{lc}\text { Landscape Component } & \text { Existing Conditions and Master Plan } \\ \text { Line } & \text { strong } \\ \text { Form } & \text { strong } \\ \text { Color } & \text { weak } \\ \text { Texture } & \text { weak } \\ \text { Sound } & \text { medium } \\ \text { Smell } & \text { weak }\end{array}$

\section{A.6 AMATIQUE BAY AND SURROUNDING LAND}

\section{A.6.1 Existing Situation}

Open ocean view horizon with low-lying land forms of native vegetation Frequent ocean-going ships to Puerto Santo Tomas and Puerto Barrios

Constant movement of small working vessels and some pleasure craft in bay. Many boats of larger size than up the Rio Dulce (i.e., sea worthy).

Development of resort viewing, ecotourism, and more developed tourism. Towns of significant size in view (Livingston and Puerto Barrios)

Initial stages of land clearing and low intensity development around part of bay.

Seaward land is nearly totally undevelop and vegetated and planned for very undeveloped ecotourism.

\section{A.6.2 Characterization of Above}

Line: Very strong horizontal lines of open sea horizon and low lying vegetated land masses.

Near developed areas are many boat masts and building walls providing vertical lines.

Form: Some rounded hills seen from developed tourism areas. Also broadside hulls of ocean-going ships often in view in distant (angular). Otherwise rounded form of bay as lagoons and inlets along shoreline. Color: Dark green of native vegetation; blues, greens, and greys of water; whites of small boats and blacks of larger ones; light colors of towns and beaches. Much open sky (whites and blues).

Texture: Generally dominated by water surface conditions from smooth to slightly course. Vegetation looks soft and fluffy due to distance in view. Towns look rough (as a whole) and smooth (walls and streets) up close. 
Sound: Many sounds of ships, human activity, and traffic around towns. Otherwise somewhat quiet with occasional navigation sounds.

Smells: Strong fish smells at times near water at towns; general ocean (seawater) smells; forest smells near less developed ecotourism areas.

\section{A.6.3 Characterization of Example Components}

Because views would generally be from long distances and Bahia de Amatique is already used heavily for commercial shipping, contrasts should not be notable.

A.6.4 Contrasts Projected from Proposed Action (barge staging area and sea-worthy tug and barge activity; navigational aids)

Line: The main contrast will be added nativational aids and mooring posts. Tugs and barges should offer little contrast to existing activities. [medium]

Form: None anticipated [weak]

Color: No contrast to existing activities and conditions [weak]

Texture: Arrangement of barges, tugs, moorings, and navigation aids may contribute to a texture change on horizon. This will be quite visible because of effect on horizon line but sea-going ships already do this to some degree [medium]

Sound: Added banging from barge handling and reloading will offer very little contrast to ongoing activities except for tourism on proposed reservation nearby [medium]

Smell: No contribution from proposed action [weak]

A.6.5 Conclusion on Number of Incompatible Landscape Contrasts (Bahia de Amatique barge mooring activity)

Landscape Component

Line

Form

Color

Texture

Sound

Smell

\author{
Existing Condition \\ medium \\ weak \\ weak \\ medium \\ medium \\ weak
}


$=$ 
ORNL/M-6691

\section{INTERNAL DISTRIBUTION}

28. J. A. Shonder

29. J. VanCoevering

30. T. J. Wilbanks

31. S. B. Wright

32. Central Research Library

33. Document Reference Section

34. Laboratory Records

35. Laboratory Records-RC

\section{EXTERNAL DISTRIBUTION}

36. Dr. Lilia A. Abron, President, PEER Consultants, P.C., 1460 Gulf Blvd., $11^{\text {th }}$ Floor, Clearwater, Florida 34630

37. Dr. Susan L. Cutter, Professor and Chair, Director, Hazards Research Lab, Department of Geography, University of South Carolina, Columbia, South Carolina 29208

38. Dr. Stephen G. Hildebrand, Director, Environmental Sciences Division, Oak Ridge National Laboratory, Post Office Box 2008, Oak Ridge, Tennessee 37831-6037

39. Romeo Martinez, 19 Calle, 14-40, Zona 1, Guatemala City, Guatemala C.A. 01009

40. Jack W. Ranney, EERC, University of Tennessee, 600 Henley Street, Suite 314, Knoxville, Tennessee 37996-4138

41. Mr. P. Richard Rittelmann, FAIA, Executive Vice President, Burt Hill Kosar Rittelmann Associates, 400 Morgan Center, Butler, Pennsylvania 16001-5977

42. Dr. Susan F. Tierney, The Economic Resource Group, Inc., One Mifflin Place, Cambridge, Massachusetts 02138

43. Dr. C. Michael Walton, Chairperson, Ernest H. Cockrell Centennial Chair in Engineering, Department of Civil Engineering, University of Texas at Austin, Austin, Texas 78712-1076 


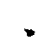

